\title{
Effects of rising air and soil temperatures on the life cycle of important pathogens in oilseed rape (Brassica napus L.) in Lower Saxony
}

\author{
Dissertation \\ to obtain the $\mathrm{Ph}$. D. degree \\ in the Faculty of Agricultural Sciences, \\ Georg-August-University Göttingen, Germany
}

presented by

Magdalena Siebold

born in Mühlhausen (Thur.) 
D7

1. Name of referee: Prof. Dr. Andreas von Tiedemann

2. Name of co-referee: Prof. Dr. Hans-Joachim Weigel

Date of dissertation: 15.11.2012 


\section{Table of contents}

CHAPTER 1: INTRODUCTION

CHAPTER 2: POTENTIAL EFFECTS OF GLOBAL WARMING ON

OILSEED RAPE PATHOGENS IN NORTHERN GERMANY

Introduction

$\begin{array}{ll}\text { Meta-analytical approach } & 7\end{array}$

$\begin{array}{lr}\text { Sclerotinia sclerotiorum } & 8\end{array}$

Leptosphaeria maculans 9

$\begin{array}{ll}\text { Verticillium longisporum } & 9\end{array}$

Alternaria spp. 11

Pyrenopeziza brassicae 11

$\begin{array}{ll}\text { Discussion } & 12\end{array}$

$\begin{array}{ll}\text { Conclusion } & 13\end{array}$

$\begin{array}{ll}\text { References } & 13\end{array}$

CHAPTER 3: APPLICATION OF A ROBUST EXPERIMENTAL METHOD

TO STUDY SOIL WARMING EFFECTS ON OILSEED RAPE

$\begin{array}{ll}\text { Introduction } & 17\end{array}$

$\begin{array}{ll}\text { Materials and Methods } & 18\end{array}$

$\begin{array}{ll}\text { Pilot study } & 18\end{array}$

$\begin{array}{ll}\text { Experimental site } & 18\end{array}$

$\begin{array}{ll}\text { Experimental design } & 18\end{array}$

Measurement of climate parameters $\quad 18$

$\begin{array}{ll}\text { Infrastructure } & 19\end{array}$ 
$\begin{array}{ll}\text { Biological measurements } & 19\end{array}$

$\begin{array}{ll}\text { Statistics } & 20\end{array}$

$\begin{array}{lr}\text { Results } & 20\end{array}$

$\begin{array}{ll}\text { Pilot study } & 20\end{array}$

Operation and performance of the field heating system 20

$\begin{array}{ll}\text { Heating effects on the soil microclimate } & 21\end{array}$

$\begin{array}{ll}\text { Heating effects on crop performance } & 22\end{array}$

$\begin{array}{ll}\text { Discussion } & 22\end{array}$

Experimental setup and system performance $\quad 22$

Heating effects on the soil microclimate 23

Heating effects on crop performance $\quad 23$

Comparison with other experimental warming methods 24

$\begin{array}{ll}\text { Conclusion } & 24\end{array}$

$\begin{array}{ll}\text { References } & 24\end{array}$

CHAPTER 4: EFFECTS OF EXPERIMENTAL WARMING ON FUNGAL 26

DISEASE PROGRESS IN OILSEED RAPE

$\begin{array}{ll}\text { Introduction } & 26\end{array}$

Materials and methods $\quad 27$

27

Climate chamber experiments with $V$. longisporum

Climate chamber experiments with S. sclerotiorum 28

Soil warming field experiments 
$\begin{array}{ll}\text { Experimental design } & 28\end{array}$

$\begin{array}{lr}\text { Fungal inoculum } & 28\end{array}$

$\begin{array}{ll}\text { Plant material and crop management } & 29\end{array}$

Phenotypic measurements, plant sampling and disease scoring 29

Measurement of plant colonization with $V$. longisporum by qPCR 29

$\begin{array}{ll}\text { Data analysis } & 29\end{array}$

$\begin{array}{ll}\text { Results } & 29\end{array}$

Effects of experimental warming on plant growth 29

Effects of experimental warming on $V$. longisporum 30

Effects of experimental warming on apothecia development of S. sclerotiorum 32

Effects of experimental warming on infection with L. maculans in the field 32

$\begin{array}{ll}\text { Discussion } & 33\end{array}$

Plant responses to experimental warming 33

Warming effects on infection with $V$. longisporum 34

Warming effects on apothecia development of S. sclerotiorum 34

Warming effects on disease severity induced by L. maculans 34

Use of degree days in warming experiments 35

Estimated pathogen prevalence in Lower Saxony under future warming 35

$\begin{array}{ll}\text { References } & 36\end{array}$

CHAPTER 5: GENERAL DISCUSSION 38

$\begin{array}{ll}\text { Summary } & 49\end{array}$

$\begin{array}{ll}\text { Appendix } & 51\end{array}$

$\begin{array}{ll}\text { Acknowledgements } & 57\end{array}$

$\begin{array}{ll}\text { Publications } & 58\end{array}$

$\begin{array}{ll}\text { Curriculum vitae } & 59\end{array}$ 


\section{Chapter 1: Introduction}

Oilseed rape (Brassica napus L.) is the most important crop for edible oil, fodder and biofuel production in Europe. In Germany, the oilseed rape cultivation area has increased in the last decades, particularly due to its properties as renewable energy source, reaching 1.5 Mio ha in 2007 and 1.3 Mio ha in 2012. Production in the last 10 years ranged from 3.6 to 6.3 Mio $t$ (Eurostat 2012). Besides adverse weather conditions, like sub- and supra-optimal temperatures, drought stress, and frost damage (Diepenbrock 2000; Kutcher et al. 2010), infection with fungal pathogens can lead to substantial yield losses, which are even reinforced by shorter crop rotations.

The economically most important oilseed rape pathogen in Germany is Phoma lingam (Leptosphaeria maculans), which causes leaf lesions in autumn (Fig. 1a, b) and severe stem and crown canker in spring, potentially leading to plant lodging (Fitt et al. 2006). Sclerotinia sclerotiorum can cause severe losses as infected stems begin to rot, leading to premature ripening in the seed filling period (Del Rio et al. 2007). Apothecia which germinate from buried sclerotia in the soil in spring (Fig. 1c) serve as inoculum source. Verticillium longisporum is a relatively new disease, mainly occurring in areas like Sweden and Northern Germany with intensive oilseed rape cultivation during the last decades (Dunker et al. 2008; Johansson et al. 2006). This pathogen can survive in the soil for many years by microsclerotia (Fig. 1d) produced on the host tissue. Verticillium inoculum probably exists in most oilseed rape growing regions in Germany (Steinbach et al. 2005). All three pathogens have in common that substantial parts of their life cycle take place in the soil or on the soil surface; hence their development is strongly influenced by the above and belowground microclimate. Climate change has been accelerated by increased anthropogenic greenhouse gas emission in the last century, and is associated with rising temperatures around the globe (IPCC 2007). In Lower Saxony, average temperatures have increased by $1.3^{\circ} \mathrm{C}$ in the last 60 years (Haberlandt et al. 2010), and a further increase of $2.5^{\circ} \mathrm{C}$ by 2100 in comparison to the baseline period 1971-2000 is projected by the regional climate models REMO and CLM (Regierungskommision Klimaschutz 2012). Rising average temperatures may lead to changes in crop phenology (Weigel 2005), but also in the occurrence of pests, pathogens and weeds (Peters and Gerowitt 2012; Tiedemann and Ulber 2008). A number of approaches have been used previously to study climate change effects on plant pathogens, such as studies along elevation or latitudinal gradients, meta-analyses, long term data monitoring or modeling approaches using one or more climate change scenarios or models (Juroszek and Tiedemann 
2012). Several modeling studies in the UK focused on climate change effects on oilseed rape pathogens (Butterworth et al. 2010; Evans et al. 2008), but for Germany similar studies are lacking. Furthermore, field manipulation experiments focusing on potential changes in oilseed rape pathogen epidemiology due to global warming do not exist so far.

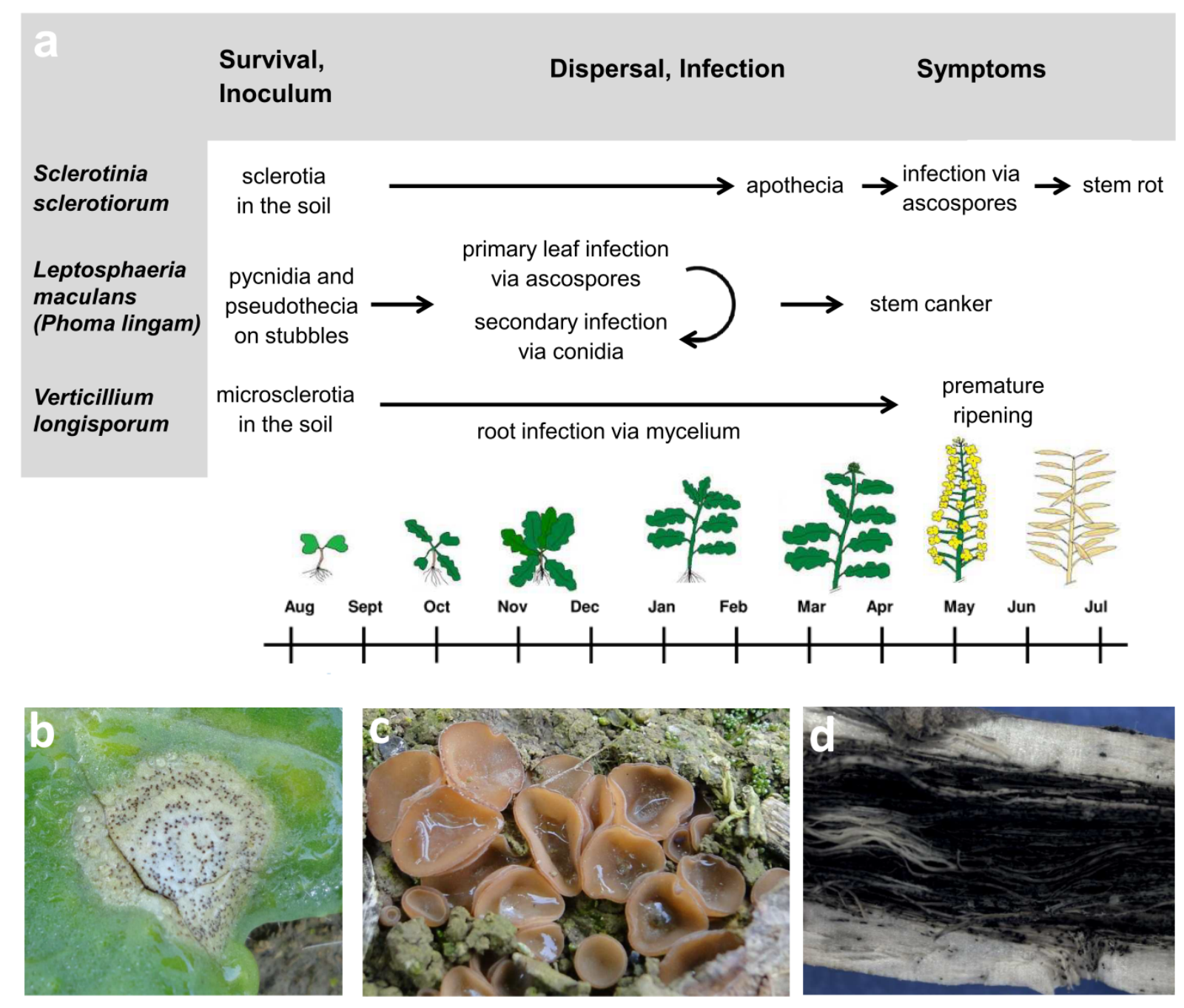

Fig. 1: Simplified life cycle of the three most important pathogens of oilseed rape in Germany in relation to crop development (a), leaf lesion featuring pycnidia of Phoma lingam (b), apothecia of Sclerotinia sclerotiorum on the soil surface (c), oilseed rape root section colonized by microsclerotia of Verticillium longisporum (d).

Recently, there has been substantial governmental funding in order to initiate climate change impact assessment projects in the light of a growing world population and food security. The research framework "KLIFF - climate impact and adaptation research in Lower Saxony" 
(Klimafolgenforschung in Niedersachsen), initiated in 2009 and funded by the Ministry for Science and Culture of Lower Saxony, is one of the first projects in Germany to investigate and assess potential effects of climate change on crop production at a regional scale within one of its research themes. The focus of this theme (FT3) is on pests, pathogens and weeds in the four most important crops in Lower Saxony: wheat, maize, oilseed rape and sugar beet.

Within KLIFF FT 3, this study had the following objectives:

1) First, existing published literature and modeling approaches dealing with climatic effects on the life cycle of economically important oilseed rape pathogens were summarized and knowledge gaps identified (Chapter 2).

2) Based on 1), potential effects of climatic change on the epidemiology of the three most important oilseed rape pathogens L. maculans, S. sclerotiorum and $V$. longisporum were investigated experimentally. To this end, a soil warming facility was constructed (Chapter 3) and experiments were additionally carried out in climate chambers, both approaches simulating regional mid- and long term warming scenarios (Chapter 4).

3) Based on the theoretical and experimental approaches, potential changes in the future prevalence of oilseed rape pathogens and consequences for farmers were derived (Chapters 4 and 5). 


\section{References}

Butterworth MH, Semenov MA, Barnes A, Moran D, West JS and Fitt BDL (2010). NorthSouth divide: contrasting impacts of climate change on crop yields in Scotland and England. Journal of The Royal Society Interface 7(42): 123-30.

Del Rio LE, Bradley CA, Henson RA, Endres GJ, Hanson BK, McKay K, Halvorson M, Porter PM, Le Gare DG and Lamey HA (2007). Impact of Sclerotinia stem rot on yield of canola. Plant Disease 91(2): 191-194.

Diepenbrock W (2000). Yield analysis of winter oilseed rape (Brassica napus L.): a review. Field Crops Research 67(1): 35-49.

Dunker S, Keunecke H, Steinbach P and Tiedemann Av (2008). Impact of Verticillium longisporum on yield and morphology of winter oilseed rape (Brassica napus) in relation to systemic spread in the plant. Journal of Phytopathology 156(11-12): 698707.

Eurostat (2012). Oilseed rape cultivation area and yield in Europe, http://epp.eurostat.ec.europa.eu/tgm/table.do?tab=table\&init=1\&plugin=1\&language= de\&pcode $=\operatorname{tag} 00099 ;$ and $=\operatorname{tag} 00104$ (verified 22.08.2012)

Evans N, Baierl A, Semenov MA, Gladders P and Fitt BDL (2008). Range and severity of a plant disease increased by global warming. Journal of The Royal Society Interface 5(22): 525-531.

Fitt BDL, Brun H, Barbetti MJ and Rimmer SR (2006). World-wide importance of Phoma stem canker (Leptosphaeria maculans and L. biglobosa) on oilseed rape (Brassica napus). European Journal of Plant Pathology 114(1): 3-15.

Haberlandt U, Belli A and Hölscher J (2010). Trends in beobachteten Zeitreihen von Temperatur und Niederschlag in Niedersachsen. Hydrologie \& Wasserbewirtschaftung 54(1): 28-36 (German with English Abstract).

IPCC (2007). Summary for Policymakers, in: Climate Change 2007: The Physical Science Basis. Contribution of Working Group I to the Fourth Assessment Report of the Intergovernmental Panel on Climate Change [Solomon, S., D. Qin, M. Manning, Z. Chen, M. Marquis, K.B. Averyt, M.Tignor and H.L. Miller (eds.)]. Cambridge University Press, Cambridge, United Kingdom and New York, NY, USA.

Johansson A, Goud J-K and Dixelius C (2006). Plant host range of Verticillium longisporum and microsclerotia density in Swedish soils. European Journal of Plant Pathology 114(2): 139-149. 
Juroszek P and Tiedemann Av (2012). Plant pathogens, insect pests and weeds in a changing global climate: a review of approaches, challenges, research gaps, key studies and concepts. The Journal of Agricultural Science: doi:10.1017/S0021859612000500.

Kutcher HR, Warland JS and Brandt SA (2010). Temperature and precipitation effects on canola yields in Saskatchewan, Canada. Agricultural and Forest Meteorology 150(2): 161-165.

Peters K and Gerowitt B (2012). How might climate change alter the interactions between weeds and crops? Julius-Kühn-Archiv 434: 35-42.

Regierungskommision Klimaschutz (2012). Empfehlung für eine niedersächsische Strategie zur Anpassung an die Folgen des Klimawandels, Niedersächsisches Ministerium für Umwelt, Energie und Klimaschutz, 113 pp., Hannover.

Steinbach P, Kreye H and Wolf GA (2005). Bundesweites "Verticillium-Monitoring" Raps 1: 20-26.

Tiedemann Av and Ulber B (2008). Verändertes Auftreten von Krankheiten und Schädlingen durch Klimaschwankungen. In: A.v. Tiedemann, R. Heitefuss and F. Feldmann (Editors), Pflanzenproduktion im Wandel - Wandel im Pflanzenschutz. Deutsche Phytomedizinische Gesellschaft, Braunschweig, Germany, pp. 79-89 (German).

Weigel HJ (2005). Healthy plants in the future: how does climate change affect crop production? Gesunde Pflanzen 57(1): 6-17 (German with English Abstract). 


\title{
Chapter 2:
}

\section{Potential effects of global warming on oilseed rape pathogens in Northern Germany}

\author{
Magdalena SIEBOLD*, Andreas von TIEDEMANN \\ University of Goettingen, Department of Crop Sciences, Division for Plant Pathology and Crop Protection,
} Grisebachstr. 6, D-37077 Goettingen, Germany

\section{A R T I C L E I N F O}

\section{Article history}

Received 23 December 2010

Revision received 2 April 2011

Accepted 2 April 2011

Available online 2 June 2011

Corresponding editor: Lynne Boddy

\section{Keywords:}

Agriculture

Alternaria brassicae

Blackleg

Climate change

Epidemiology

Leptosphaeria maculans

Pyrenopeziza brassicae

Sclerotinia stem rot

Verticillium longisporum

\section{A B S T R A C T}

This review analyses potential effects of global warming, i.e. higher mean temperatures, on the life cycle of five economically important oilseed rape pathogens in Northern Germany using a meta-analytical approach. First, the currently available but strongly fragmented knowledge about temperature influences on individual life cycle stages of the referred pathogens, such as survival, sporulation, infection and disease progress is summarised. These data are compared with current regional climate projections (REMO model) based on emission scenario A1B for the periods 2001-2030 and 2071-2100 in three different oilseed rape growing regions in Lower Saxony, Germany, using a baseline historical series of meteorological data collected from 1971 to 2000. Our analysis suggests that warming might lead to shifts in the future prevalence of these pathogens. Verticillium longisporum, Sclerotinia sclerotiorum and Alternaria brassicae could be particularly favoured, but beneficial effects may also occur for certain life cycle stages of Phoma lingam, such as infection and stem canker development. Pyrenopeziza brassicae might even lose importance under future warming. These changes may be particularly explicit in the long-term view (2071-2100). However, predictions on potential disease shifts are restricted by a lack of reliable, highresolution future climate scenarios and complicated by the prospective adaptations of farming techniques and crop genotypes to climate change.

(c) 2011 Elsevier Ltd and The British Mycological Society. All rights reserved.

\section{Introduction}

The current hypotheses of global climate change mainly focus on projections for temperature, rainfall and air/soil humidity (Olesen \& Bindi 2002). In Europe, temperatures are assumed to increase, especially at higher latitudes, during night time and in winter months (Rosenzweig et al. 2001). Specific consequences, extrapolated from Global Climate Models (GCMs), may be higher winter precipitation, summer droughts and changing precipitation patterns during spring (IPCC 2007). Future changes in cloud development and distribution are the single biggest source of uncertainty in climate projections (Karl \&
Trenberth 2003), suggesting that it is very difficult to project future precipitation patterns on a regional and local scale. In addition, the low spatial resolution of climate models increases this uncertainty further (Scherm et al. 2000).

Most researchers agree that besides changes in mean climate variables greater climate variability and occurrence of extreme events have to be taken into account in future agricultural production systems (Rosenzweig et al. 2001; Tubiello et al. 2007). A potential consequence of global change on agricultural production is the pole-ward shift of agro-climatic zones (Tiedemann 1996; Coakley et al. 1999; Chakraborty et al. 2000) and an earlier and faster development of crops in existing

\footnotetext{
* Corresponding author. Tel.: +4955139 14090; fax: +49551393706.

E-mail address: msiebol@gwdg.de (M. Siebold).

1754-5048/\$ - see front matter @ 2011 Elsevier Ltd and The British Mycological Society. All rights reserved. doi:10.1016/j.funeco.2011.04.003
} 
production zones. Diseases are likely to expand their geographic range to higher latitudes at the same time (Scherm et al. 2000; Rosenzweig et al. 2001).

Weather is a major driver for the occurrence of plant diseases (Anderson et al. 2004), followed by cultivar resistance and farming techniques. Plant pathogens are highly responsive to humidity, rainfall and temperature (Coakley 1988). Temperature is considered as the single most important environmental factor affecting the development and spread of pathogens (Analytis 1977). Single extreme minimum temperatures can be more important than monthly average minima (Seem et al. 2000). Elevated moisture in the form of precipitation and relative humidity, on the other hand, is favourable for infection, sporulation, spore release and germination of most fungal pathogens, unless they thrive in hot and dry environmental conditions such as Ustilago species. Moist conditions for infection and sporulation of foliar pathogens are most commonly provided during overnight dewfall, thus optimal temperatures for the specific developmental stage are particularly important during this time period (Harvell et al. 2002).

There have been numerous studies on how climate change might affect fungal diseases. Increased temperatures and UV radiation may promote fungal reproduction (Manning \& Tiedemann 1995; Rosenzweig et al. 2001). Milder and wetter winters may increase the survival of plant debris-borne fung like Alternaria, Cercospora and seedling diseases, while soilborne fungi like Fusarium, Rhizoctonia, Sclerotinia and Verticillium might not be significantly affected (Rosenzweig et al. 2001; Boland et al. 2004; Roos et al. 2011). Also, powdery mildew, leaf rust and stripe rust may be favoured by milder winters (Fuhrer 2003). Increased overwintering of sexual propagules may increase the fitness of certain fungal populations (Garrett et al. 2006). Warmer and drier summers, on the other hand, have been often associated with decreased threat by fungal pathogens (Fuhrer 2003; Boland et al. 2004 Weigel 2005). In contrast to monocyclic diseases, polycyclic diseases might be more affected by climate change by having more cycles during longer growing periods or fewer cycles due to drier summers (Boland et al. 2004). This does not exclude the possibility that disease severity by monocyclic vascular wilts and root rots could be altered as well, for example, due to heat and drought stress of the plant as a reaction to higher summer temperatures (Boland et al. 2004). Shifts in pathogen spectra, e.g. from stripe rust to leaf rust or from powdery mildew to leaf spot diseases in cereals, as well as the appearance of new pathogens (e.g. Verticillium longisporum in oilseed rape or Ramularia collo-cygni in barley) have already been observed in Germany (Tiedemann \& Ulber 2008). However, it is difficult to assign such shifts to climatic factors alone, since agronomical factors have consistently changed as well.

Oilseed rape (Brassica napus) is the most important crop for edible oil, fodder and bio-fuel production in Europe. Under climate change, oilseed rape is likely to spread further into Northern and Eastern Europe and remains very widespread throughout Southern and Central Europe, whereas a decline in Southwest Europe may occur (Tuck et al. 2006; Peltonen-Sainio et al. 2009). The oilseed rape cultivation area in Germany has reached 1.5 million ha in 2010. Within Germany, Lower Saxony is one of the federal states with the largest increase in oilseed rape cultivation (around 140.000 ha in 2009) in recent years and the second highest average yield in Germany 2009 (45.4 dt ha ${ }^{-1}$, Anonymus 2009). Climate change will not only alter the distribution of oilseed rape growing regions, but also affect the development and prevalence of fungal pathogens. For example, leaf diseases may be reduced by higher temperatures and reduced leaf wetness compared to stem diseases (Tiedemann 1996). This review paper focuses on fungal diseases of oilseed rape. It presents a straightforward approach to assess the impact of warming on different life cycle stages of the currently most important fungal pathogens of oilseed rape in Germany, based on regional climate model projections.

\section{Meta-analytical approach}

Predictions of climate change impacts on crop plant diseases essentially rely on sufficient knowledge about environmental requirements of individual pathogens. Most fungal pathogens are active in a wide temperature range but also have distinct optimum conditions (Boland et al. 2004). There are numerous studies on impacts of environmental factors on the epidemiology and population dynamics of fungal diseases, but data are strongly fragmented and of variable quality (Tiedemann \& Ulber 2008). The aims of this paper therefore are to (i) summarise the published knowledge about weather effects on disease epidemiology; and (ii) estimate the future prevalence of the diseases according to warming scenarios at three different oilseed rape growing regions in Lower Saxony.

The available knowledge on disease epidemiology of the fungal pathogens discussed in this review is summarised in Table 1. Most data on fungal life cycle stages and epidemic development were obtained from controlled environment studies, supplemented by greenhouse and field observations. As the different life cycle stages of fungal pathogens have different climatic requirements they are considered separately in this study with emphasis on the most relevant stages for disease development and crop yield loss (De Wolf \& Isard 2007).

Three locations in Lower Saxony, Goslar, Celle and Cuxhaven, were chosen to represent three different regions along a topographic and climatic gradient (Fig 1 and 2). Cuxhaven is situated at the German North Sea coast (altitude $2 \mathrm{~m}$ ) with mild winters and increased precipitation in the second half of the year. Celle (altitude $40 \mathrm{~m}$ ), at the Southern edge of the Luneburg Heath in Central Lower Saxony, typically has warm summers and evenly distributed precipitation on a lower level than Cuxhaven. Goslar is located in the middle-German downs (altitude $266 \mathrm{~m}$ ) with cold winters and lower levels of precipitation compared to Cuxhaven and Celle. Climate change projections for these regions in Lower Saxony for the periods 2001-2030 and 2071-2100 are based on data obtained from the regional climate model REMO using Scenario A1B (Jacob \& Podzun 1997; Werner \& Gerstengarbe 2007).

From the wide temperature range reported in the literature, only optimum temperatures, at which fungal development is fastest or infection is most severe, were plotted for each distinguishable stage in the fungal life cycle (Fig 3a-e). Consideration of pathogen responses to climate shift was differentiated by fungal developmental stages (Table 2), which is lacking in most previous review papers and allows for 


\begin{tabular}{|c|c|c|c|c|c|}
\hline \multirow[t]{2}{*}{ Pathogen } & \multicolumn{4}{|c|}{ Life cycle stages } & \multirow{2}{*}{$\begin{array}{l}\text { Modelling } \\
\text { approaches }\end{array}$} \\
\hline & Survival & Sporulation & Infection & Disease progress & \\
\hline Sclerotinia sclerotiorum $(n=97)$ & $\boldsymbol{r}$ & $\boldsymbol{v}$ & $\nu$ & $\boldsymbol{r}$ & $P$ \\
\hline Leptosphaeria maculans $(n=74)$ & $\boldsymbol{\nu}$ & $\boldsymbol{\nu}$ & $\boldsymbol{\nu}$ & $\boldsymbol{\nu}$ & $\mathrm{P}$ \\
\hline Verticillium longisporum $(n=37)$ & $?$ & $?$ & $\mathrm{x}$ & $?$ & $\mathrm{x}$ \\
\hline Alternaria brassicae $(n=15)$ & $?$ & $\boldsymbol{V}$ & $\boldsymbol{}$ & レ & $*$ \\
\hline Pyrenopeziza brassicae $(n=36)$ & $\mathrm{x}$ & $\boldsymbol{V}$ & $?$ & $?$ & $\mathrm{P}$ \\
\hline
\end{tabular}

a more detailed assessment of potential future changes in disease prevalence and severity.

\section{Sclerotinia sclerotiorum}

The monocyclic ascomycete S. sclerotiorum affects numerous agricultural crops around the world, but is most common in temperate regions (Willetts et al. 1980). It is one of the most devastating plant pathogens with the potential to cause significant yield losses (up to $50 \%$ ) to numerous host plants including oilseed rape (Bolton et al. 2006). The fungus survives by sclerotia developed in infected plant parts such as oilseed rape stems and buried in the soil after harvest. Sclerotia survive a wide range of adverse conditions such as heat and drought in the soil (Coley-Smith \& Cooke 1971).

There are two possible ways of infection: carpogenic germination of sclerotia with subsequent production of ascospores, or myceliogenic germination of sclerotia (Bolton et al. 2006). Myceliogenic germination of S. sclerotiorum occurs over a temperature range of $12-24^{\circ} \mathrm{C}$, but its epidemic importance in oilseed rape is still unclear. Carpogenic germination of sclerotia

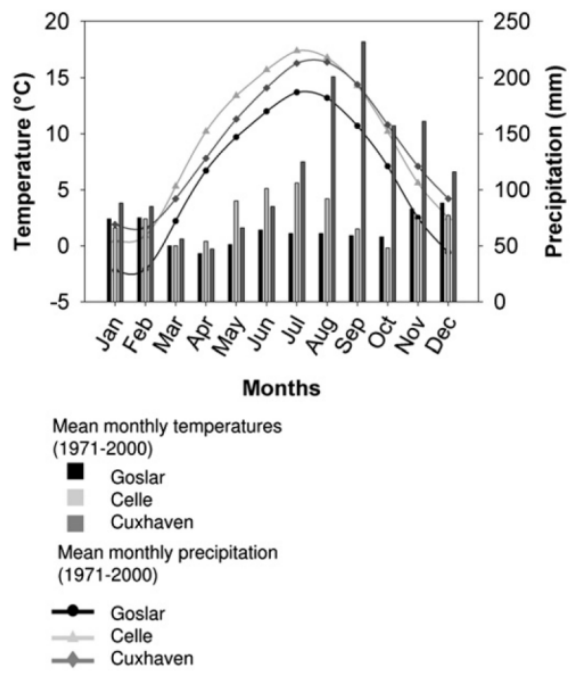

Fig 1 - Mean monthly temperatures and precipitation in three different regions in Lower Saxony, Germany, during the period 1971-2000. Data source: German Weather Service (DWD). is significantly influenced by the isolate and age of sclerotia (Huang \& Kozub 1991, 1994). Most studies agree that sclerotia need a period of preconditioning in order to trigger apothecia production. However, statements concerning the temperature and duration of preconditioning vary widely, with temperature ranges between $-10^{\circ} \mathrm{C}$ and up to $20^{\circ} \mathrm{C}$ being reported as necessary for apothecia development (Willetts et al. 1980). A broad corridor of favourable temperatures between 7 and $24{ }^{\circ} \mathrm{C}$ has been reported for carpogenic germination in spring, again varying depending on the origin of the isolate (Hao et al. 2003; Wu \& Subbarao 2008). More important than optimal temperature, however, is high and continuous soil moisture for at least $10 \mathrm{~d}$ (Abawi \& Grogan 1979). Requirements of a soil water potential between -0.008 and $-0.5 \mathrm{MPa}$ has also been reported (Hao et al. 2003). Ascospore production and germination are

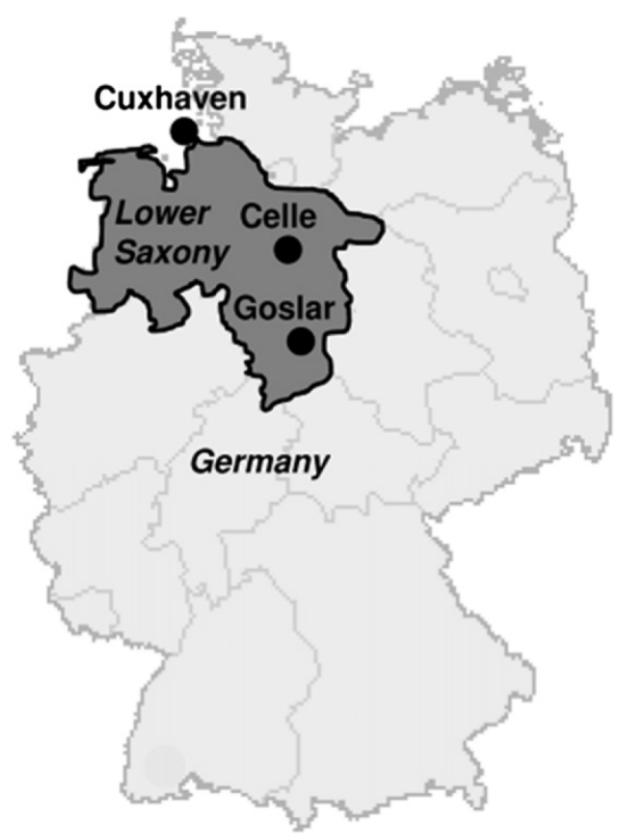

Fig 2 - Geographic position of the three reference locations for representative oilseed rape growing regions in the federal state of Lower Saxony, Germany (Cuxhaven, Celle and Goslar). The state of Lower Saxony is highlighted in dark grey. 
most favoured by temperatures between 12 and $25^{\circ} \mathrm{C}$, optimum moisture conditions for ascospore germination are $16-48 \mathrm{hr}$ of leaf wetness or relative humidity $(\mathrm{RH})>92 \%$ (Abawi \& Grogan 1979; Clarkson et al. 2003; Young et al. 2004).

Infection of crops by ascospores and lesion development require temperatures between 12 and $25^{\circ} \mathrm{C}$ (Abawi \& Grogan 1979; Willetts et al. 1980; Heran et al. 1999; Young et al. 2004), and a minimum of $16-23 \mathrm{hr}$ of leaf wetness (Willetts et al. 1980; Koch \& Tiedemann 2005), with an optimum between 48 and $72 \mathrm{hr}$ and $\mathrm{RH}>90 \%$ (Abawi \& Grogan 1979; Boland \& Hall 1988). Moisture is less limiting during the later stages of disease development.

The temperature optimum for each developmental stage follows the natural temperature progress during spring and early summer (Fig 3a). Current climate in Celle is currently more favourable for carpogenic germination and infection than in Goslar or Cuxhaven. Global warming, however, may shift the monthly mean temperatures closer to the optimum temperature range of the pathogen in all three locations, particularly in the longer term (2071-2100). Warming may also enhance the infection window for this pathogen (Tiedemann \& Ulber 2008; Evans et al. 2009), both in the mid and longer term, possibly leading to earlier infections at all three locations in the future, given that enough moisture for fungal development is available. This assumption is supported by observations in previous years, where milder winter conditions already lead to pre-seasonal epidemics before flowering in early spring in Germany and France (Evans et al. 2009). Besides flower infection, root and young plant infections may become more common. For most life cycle stages, however, sufficient moisture will be a crucial determinant of the future importance of the disease.

\section{Leptosphaeria maculans (Anamorph: Phoma lingam)}

The Phoma blackleg and stem canker complex are the economically most important disease of oilseed rape in Germany, frequently leading to severe yield losses (Bremer 2007). The monocyclic ascomycete, L. maculans, survives as pseudothecia on crop residues (Hershman \& Perkins 1995), but pycnidia survival between growing seasons has also been reported (Travadon et al. 2007). Pseudothecia maturation takes place from 7 to $25^{\circ} \mathrm{C}$ and at $\mathrm{RH}>95 \%$ or $1-1.5 \mathrm{~mm}$ rainfall $\mathrm{d}^{-1}$ (Pérès et al. 1999; Guo \& Fernando 2005; Fitt et al. 2006a Khangura et al. 2007). Ascospores are released from the fruit bodies in autumn and spring (Thürwächter et al. 1999). Ascospore discharge and germination occur over a wide temperature range from 4 to $30^{\circ} \mathrm{C}$ and are favoured at $100 \% \mathrm{RH}$ or rainfall > $2 \mathrm{~mm}$ (Hall 1992; Huang et al. 2003, 2005; Guo \& Fernando 2005). Primary infection of oilseed rape leaves takes place in autumn or spring, while secondary infection is initiated by conidia released from pycnidia in autumn or spring. Pycnidia develop between 5 and $30^{\circ} \mathrm{C}$ and at $1-8$ d leaf wetness duration, the temperature range for release and germination of conidia is similar but requires only $16 \mathrm{hr}$ leaf wetness (Hall 1992). Crop infection occurs from 5 to $24^{\circ} \mathrm{C}$ with optimum temperatures between 10 and $20^{\circ} \mathrm{C}$ and 8 to $72 \mathrm{hr}$ of leaf wetness (Biddulph et al. 1999; Huang et al. 2003, 2005). Leaf spot development is most favoured between 5 and $20^{\circ} \mathrm{C}$ and at $48 \mathrm{hr}$ of leaf wetness, while stem canker development requires slightly higher optimum temperatures of $12-25^{\circ} \mathrm{C}$ (Hall 1992; Biddulph et al. 1999; Huang et al. 2005).

At Celle and Cuxhaven, P. lingam is already in its optimum temperature range for initial developmental stages in autumn, such as pseudothecia maturation and ascospore production (Fig 3b). Optimum temperature requirements for infection, however, are slightly higher than current temperatures at all three locations, thus the infection period in autumn may be extended under future warming. Additionally, milder winters in the future may favour disease severity by lack of leaf shedding, enabling the fungus to grow from leaf lesions systemically into the stem and to cause stem canker in the following spring (Fitt et al. 2006b; Bremer 2007; Tiedemann \& Ulber 2008). In cooler regions, such as Goslar, however, harder winters may still cause partial losses of oilseed rape leaves, resulting in less canker development. Conidia need higher temperatures for germination than ascospores, thus their importance in the fungal disease cycle may increase under warmer temperatures. Sufficient moisture, however, will remain a key factor for the occurrence of the disease.

\section{Verticillium longisporum comb. nov.}

The ascomycete $\mathrm{V}$. longisporum is a relatively recent problem of oilseed rape cultivation, being particularly widespread in cooler parts of Europe (Evans et al. 2009). In these regions it can cause yield losses up to $50 \%$ (Daebeler et al. 1988; Zeise \& Steinbach 2004). It has only recently been classified as V. longisporum comb. nov. (Karapapa et al. 1997), and some earlier reports on Verticillium disease in oilseed rape refer to Verticillium dahliae. V. longisporum survives unsuitable conditions as microsclerotia buried in the soil or resting on crop debris after harvest (Domsch et al. 1980). There is no spread by aerial spores, thus dispersal takes place via transfer of crop residues or soil through tillage devices. Microsclerotia germinate most readily at soil water potentials of $>-1 \mathrm{MPa}$ and temperatures above $15^{\circ} \mathrm{C}$ (Domsch et al. 1980; Soesanto \& Termorshuizen 2001; Dunker \& Tiedemann 2006), which are also most favourable for mycelial growth, invasion of the roots and spread of the fungus within the stem (Domsch et al. 1980; Schnathorst 1981; Donald \& Czeslaw 1998; Pegg \& Brady 2002). After invasion of the xylem, the fungus proliferates with conidia which are transported in the xylem stream and initiate new infection sites. Disease progress and symptom development are favoured by temperatures above $20^{\circ} \mathrm{C}$ and low soil moisture (Schnathorst 1981; Zeise \& Seidel 1990; Pegg \& Brady 2002). Towards crop ripening, dark microsclerotia are produced over a wide temperature range (Ioannou et al. 1977; Domsch et al. 1980; Soesanto \& Termorshuizen 2001).

In general, the existing knowledge on $\mathrm{V}$. longisporum epidemiology is not sufficient to predict confidently potential climate change effects. Nevertheless, the scarce available data imply that Verticillium has a temperature optimum above $20^{\circ} \mathrm{C}$ for most life cycle stages (Fig 3c). Current mean air temperatures at Goslar, Celle and Cuxhaven are clearly below the optimum temperature required by the fungus. Thus, it seems that warming would be favourable to $\mathrm{V}$. longisporum in the future, which is in agreement with observations that the disease has occurred more frequently in recent warmer years. The apparent contradiction between disease occurrence 
a

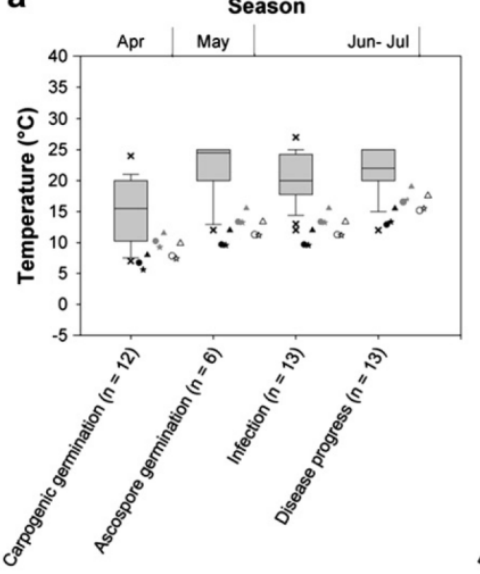

Developmental stage

C

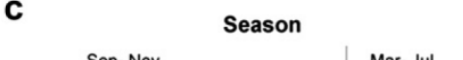

b
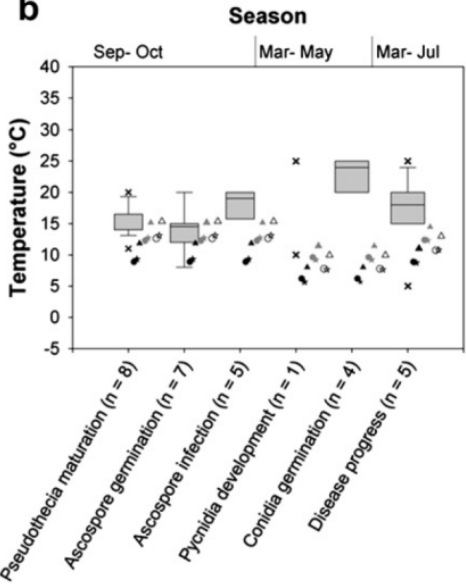

d

Developmental stage
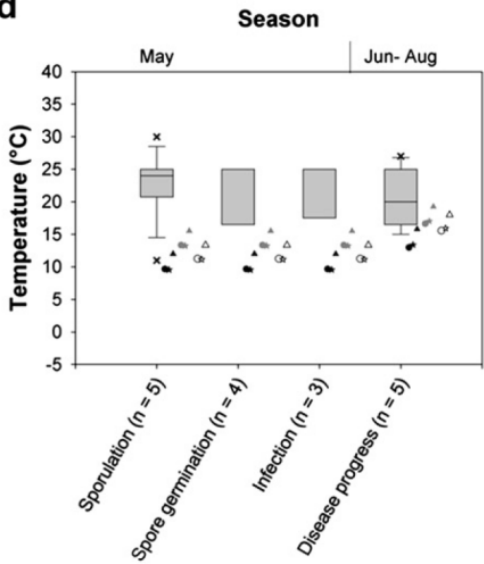

Developmental stage

e

Developmental stage

40 Mar- Aug Sep- Nov Sep- Feb Mar- May

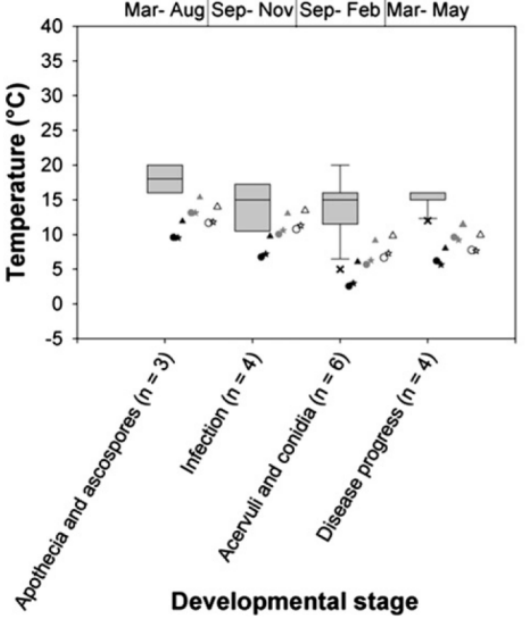

Mean monthly temperatures

$\begin{array}{ll} & \text { Goslar } \\ & \text { Celle } \\ \square & \text { Cuxhaven } \\ \text { } & 1971-2000 \\ \star & 2001-2030 \text { (REMO) } \\ \boldsymbol{\Delta} & 2071-2100 \text { (REMO) }\end{array}$




\begin{tabular}{|c|c|c|}
\hline Pathogen & Life cycle stage & $\begin{array}{l}\text { Corresponding } \\
\text { weather data } \\
\text { period }\end{array}$ \\
\hline $\begin{array}{l}\text { Sclerotinia } \\
\text { sclerotiorum }\end{array}$ & $\begin{array}{l}\text { Carpogenic germination } \\
\text { Ascospore germination } \\
\text { Infection } \\
\text { Disease progress }\end{array}$ & $\begin{array}{l}\text { Apr. } \\
\text { May } \\
\text { May } \\
\text { Jun., Jul }\end{array}$ \\
\hline $\begin{array}{l}\text { Leptosphaeria } \\
\text { maculans }\end{array}$ & $\begin{array}{l}\text { Pseudothecia maturation } \\
\text { Ascospore germination } \\
\text { Ascospore infection } \\
\text { Pycnidia development } \\
\text { Conidia germination } \\
\text { Disease progress }\end{array}$ & $\begin{array}{l}\text { Sep.-Oct. } \\
\text { Sep.-Oct. } \\
\text { Sep.-Nov. } \\
\text { Mar.-May } \\
\text { Mar.-May } \\
\text { Mar.-Jul. }\end{array}$ \\
\hline $\begin{array}{l}\text { Verticillium } \\
\text { longisporum }\end{array}$ & $\begin{array}{l}\text { Microsclerotia germination } \\
\text { Mycelial growth } \\
\text { Infection } \\
\text { Disease progress }\end{array}$ & $\begin{array}{l}\text { Sep.-Nov. } \\
\text { Sep.-Nov. } \\
\text { Sep.-Nov. } \\
\text { Mar.-May }\end{array}$ \\
\hline $\begin{array}{l}\text { Alternaria } \\
\text { brassicae }\end{array}$ & $\begin{array}{l}\text { Sporulation } \\
\text { Spore germination } \\
\text { Infection } \\
\text { Disease progress }\end{array}$ & $\begin{array}{l}\text { May } \\
\text { May } \\
\text { May } \\
\text { Jun.-Aug. }\end{array}$ \\
\hline $\begin{array}{c}\text { Pyrenopeziza } \\
\text { brassicae }\end{array}$ & $\begin{array}{l}\text { Apothecia and ascospores } \\
\text { Infection } \\
\text { Acervuli and conidia } \\
\text { Disease progress }\end{array}$ & $\begin{array}{l}\text { Mar.-Aug. } \\
\text { Sep.-Nov. } \\
\text { Sep.-Feb. } \\
\text { Mar.-May }\end{array}$ \\
\hline
\end{tabular}

mainly in Northern Germany and higher temperature requirements of the fungus may be explained by the longer history of oilseed rape production and closer crop rotations in the coastal regions. Global warming will also increase soil temperature, at least in the upper layers where fungal inoculum is present (Zhang et al. 2005), and may finally shift soil temperatures towards the biological optimum of the fungus at locations where the disease is currently not a problem. Thus, although $\mathrm{V}$. longisporum is a xylem-invading fungus, early stages of the life cycle, such as microsclerotia germination and root infection, are likely to be favoured by warming. In addition, the infection period may be extended at higher temperatures (Dunker et al. 2008; Evans et al. 2009).

\section{Alternaria spp.}

Alternaria blight is a common disease in most parts of Europe, but seldom causes significant yield losses in Germany. The disease is caused by Alternaria brassicae and Alternaria brassicicola which survive by conidia, chlamydospores or stroma in the soil or on crop residues. Sporulation, infection of leaves and disease development are most favoured at $15-25^{\circ} \mathrm{C}$ (Degenhardt et al. 1982; Humpherson-Jones \& Phelps 1989; Mridha \& Wheeler 1993; Hong \& Fitt 1996). Secondary conidia of this polycyclic pathogen can be produced at slightly lower temperatures of $11-23^{\circ} \mathrm{C}$ (Degenhardt et al. 1982). Hence, all developmental stages of the fungus have a similar temperature optimum. Sporulation is favoured at $>87 \% \mathrm{RH}$ (Humpherson-Jones \& Phelps 1989). Infection requires around $8 \mathrm{hr}$ of leaf wetness (Mridha \& Wheeler 1993) and is favoured by a wetness period of 1-3 d (Hong \& Fitt 1996). Leaf spots are not damaging, but severe losses may occur when the fungus spreads onto pods.

The collected data (Fig 3d) might offer one explanation why Alternaria is of minor importance in oilseed rape crops in Germany at present. The optimum temperature for all stages of the fungal life cycle is around $20^{\circ} \mathrm{C}$, but mean temperatures at Goslar, Celle and Cuxhaven are clearly below these requirements. Consequently, future warming may lead to earlier and more severe Alternaria epidemics and a higher number of disease cycles per year, at least in the regions of Celle and Cuxhaven during the period 2071-2100. Cooler regions in higher altitudes, such as Goslar, may still be suboptimal for Alternaria epidemics.

\section{Pyrenopeziza brassicae (anamorph: Cylindrosporium} concentricum)

The ascomycete $P$. brassicae is one of the most important pathogens of oilseed rape in the UK, France and coastal regions of Northern Europe. It causes light leaf spot disease, which is favoured by mild autumn and winter conditions. In Germany, light leaf spot occurs mainly in Northern parts, but without great damage potential (Daebeler et al. 1992; Tiedemann 2004). The fungus survives mostly as conidia or mycelium on crop residues or other cruciferous plants during the summer. Conidia are transported by rain and wind to the host plants. Apothecia and ascospore production for survival are frequent in the UK but seldom in Germany (Paul et al. 1990) and most favoured at $16-20^{\circ} \mathrm{C}$ (Karolewski et al. 2002, 2004). Main infection periods are Oct. and Apr. until May. Most favourable for infection are temperatures from 10 to $15^{\circ} \mathrm{C}$ and $6-16 \mathrm{hr}$ of leaf wetness (Figueroa et al. 1995; Fitt et al. 1998; Karolewski et al. 2002). The fungus spreads in the field by conidia produced in acervuli. Acervulus development takes place at $4-20^{\circ} \mathrm{C}$ and $6-24 \mathrm{hr}$ of leaf wetness (Gilles et al. 2000; Karolewski et al. 2002). Conidia are produced and released at $5-15^{\circ} \mathrm{C}$, and for conidia germination a wetness period of $16 \mathrm{hr}$ is required (Paul et al. 1990; Fitt et al. 1998; Karolewski et al. 2004). The number of asexual cycles depends on the

Fig 3 - Optimum temperatures for each distinguishable stage in the fungal life cycle of (a) Sclerotinia sclerotiorum, (b) Leptosphaeria maculans/Phoma lingam, (c) Verticillium longisporum, (d) Alternaria brassicae and (e) Pyrenopeziza brassicae/ Cylindrosporium concentricum plotted against the increase of projected monthly mean air temperature due to global warming in Cuxhaven, Celle and Goslar. Grey boxes indicate the range of optimum temperatures (at which fungal development is fastest or infection is most severe) of the pathogens specific for each developmental stage. The median represents the optimum temperature reported in most studies. Season on the $z$-axis refers to both the time of year when the individual life cycle stage is usually taking place or initiated and the corresponding time periods from which means of monthly temperatures were used for the projections (compare Table 2) in three oilseed rape growing regions and three time horizons (2000, 2030 and 2100), $n=$ number of references included in the analysis. 
occurrence of favourable weather conditions, and often only the asexual cycle may occur (Paul et al. 1990). First clear symptoms usually appear in late spring. Disease development is most favoured at temperatures around $15^{\circ} \mathrm{C}$ and suppressed at $>20^{\circ} \mathrm{C}$, and $16-48 \mathrm{hr}$ of leaf wetness are required (Figueroa et al. 1995; Gilles et al. 2000; Karolewski et al. 2002).

Altogether, P. brassicae needs mild to cool and moist conditions from autumn to spring (Fig 3e), which is a major part of the season. Mean monthly temperatures at Celle and Cuxhaven, however, already reach the optimum temperature range for infection of this pathogen. Thus, further warming might adversely affect fungal development by exceeding the optimum temperature range more often (Schrödter 1965), particularly in the longer term. This may prevent apothecia development in spring and summer, which is delayed or inhibited by temperatures $>20^{\circ} \mathrm{C}$. On the other hand, conidia development may be favoured by warmer winters. The cooler climate in Goslar, however, may still be conducive to light leaf spot in the future.

\section{Discussion}

This study has summarised the existing knowledge of climatic effects on the life cycle of five fungal pathogens of oilseed rape and tried to assess their potential future prevalence according to current and predicted temperatures at three oilseed rape growing regions in Lower Saxony, Germany. It has shown that $S$. sclerotiorum, V. longisporum and Alternaria spp. may be favoured by warmer temperatures by reaching their optimum temperatures required for certain important life cycle stages. P. lingam is currently in its optimum temperature range during autumn, but may be indirectly favoured by warming if less leaf loss occurs during winter, enabling systemic spread from leaves into the stem to cause stem canker. Temperatures might even exceed the optimum required for infection by P. brassicae, which may therefore not be favoured by further warming in Lower Saxony. These trends are likely to be more evident in the longer term (2071-2100) rather than in the middle-term (2001-2030).

The use of mean temperatures to predict any event in the life cycle of pathogens has been criticised for various reasons. Mean daily temperatures do not reflect the actual temperatures experienced by pathogens whose development is influenced by the frequency of favourable and non-favourable temperatures on an hourly basis (Schrödter 1965). Projected climate scenarios often have a lower temporal resolution than biological processes like spore discharge, spore germination and infection of the host plants, which take place over a daily or sub-daily time scale (Scherm \& van Bruggen 1994). Nevertheless, the approach chosen in this study may be useful to estimate how the prevalence of individual pathogens might change in the future, particularly if distinct life cycle stages can be assigned to longer time periods in the season with predicted overall changes in climate. A step towards assessing short-term events in the fungal life cycle more reliably would be to including extreme daily temperatures predicted for the future (Schrödter 1965). However, short-term weather events will probably remain difficult to predict.

The analysis presented here is focussed on optimum temperature conditions for the life cycle of the five pathogens, as future temperatures are predictable with higher certainty by climate models than any other climatic factors, such as cloud formation, precipitation, relative humidity, soil moisture or extreme weather events. However, while moisture is one of the most important determinants of fungal pathogen growth, previous reports on its impact are contradictory. S. sclerotiorum requires elevated soil moisture for a longer period during spring in order to produce apothecia. If changing precipitation patterns in spring occur in the future, the crop canopy may still provide a moist microclimate required by the pathogen. Since only short periods of leaf wetness are required for sporulation and infection, these processes are unlikely to be compromised by future changing precipitation patterns projected for spring. P. lingam, on the other hand, depends on longer moisture periods in autumn and spring for spore discharge and subsequent infection. From the pathogens analysed here, V. longisporum may be the most independent from both soil moisture and precipitation, as far as can be deduced from current published knowledge. A. brassicae depends on both relatively high temperatures and the duration of leaf wetness periods to complete its life cycle, which will determine disease severity in the future. P. brassicae needs both cool and moist conditions, but temperature may be a stronger limiter of disease outbreak in the future than availability of high moisture.

Plasmodiophora brassicae, a soilborne pathogen which can regionally cause severe outbreaks of clubroot disease of Brassicaceae, was not analysed in detail in this review, since soil moisture, a factor particularly difficult to predict, is the most important environmental factor affecting movement of zoospores in the soil and subsequent infection of the host plant. Soil temperatures around $25^{\circ} \mathrm{C}$ may be additionally favourable for disease development (Dixon 2009). In contrast to Verticillium, however, clubroot may continue to cause significant yield losses in moist and acid soils.

In general, optimum temperature conditions may reduce required duration of moisture periods for rapid development of the pathogens. Temperature may be the most important factor limiting fungal pathogen development in autumn, winter and spring, while moisture will be particularly limiting in spring and summer (Müller 2005).

This study has not considered warming effects on crop performance. Warming may affect the length of the growing season for determinate species like oilseed rape (Olesen \& Bindi 2002; Weigel 2005). Rising temperatures are associated with phenological advance across the Northern hemisphere, leading to an advance of leafing and flowering of crops by $4 \mathrm{~d} /$ degree Celsius in Germany (Estrella et al. 2007). Earlier flowering of oilseed rape crops might have a neutral impact on S. sclerotiorum, whose development may also shift to earlier in the year. Warming allows earlier planting and harvesting of spring crops, while milder winters might allow growing of more productive cultivars, potentially leading to higher yields (Olesen \& Bindi 2002). Cultivar choice, on the other hand, may also influence the susceptibility to a certain pathogen at a given temperature (Colhoun 1973). Overall, both negative and positive effects on plant growth are likely to occur at the same time resulting in inverse effects on diseases.

Effects of elevated $\mathrm{CO}_{2}$ on crop morphology and physiology and its impact on resistance to fungal pathogens have been reviewed in detail previously (Goudriaan \& Zadoks 1995; Manning \& Tiedemann 1995; Chakraborty et al. 2000; Olesen \& 
Bindi 2002; Chakraborty et al. 2008; Ghini et al. 2008). The predominant effect was an increased resource use efficiency and resistance of the host plant, but also the possible emergence of more aggressive pathogens (Coakley et al. 1999; Chakraborty \& Datta 2003). Altered C:N ratios in host tissue and increased crop canopy structure might favour leaf diseases like blights, rusts, leaf spots and powdery mildews (Hibberd et al. 1996), as well as soilborne pathogens due to increased root biomass (Manning \& Tiedemann 1995). While increased $\mathrm{CO}_{2}$ may stimulate fungal epidemics, increased levels of $\mathrm{O}_{3}$ and UV-B irradiation may restrict fungal development (Eastburn et al. 2010). However, these effects may be more adverse for the crops than for the related pathogens (Manning \& Tiedemann 1995). Finally, interactions of several climate factors, such as temperature and precipitation with $\mathrm{CO}_{2}$ concentration and air pollutants (Weigel 2005), need to be considered more strongly in experiments in the future.

In the present review each fungal pathogen has been considered separately. However, there may be interactions between two or more pathogens, or between a pathogen and insects, which may injure the plants, promoting the direct entry of pathogens like $P$. lingam or $V$. longisporum into the stem (Tiedemann 1996; Keunecke 2009). Warming might also influence fungal development indirectly by chemical alteration of pesticides (Rosenzweig et al. 2001) and increased fungicide uptake by the host plants (Scherm \& van Bruggen 1994). Finally, adaptation of tillage and management strategies by farmers as response to climate change may have even bigger impacts on occurrence and distribution of fungal pathogens than climate change itself (Tiedemann 1996; Juroszek \& Tiedemann 2011). A general conclusion is that climate change may have a positive, negative or neutral impact on diseases, resulting in a shift in their practical relevance (Chakraborty et al. 2000). Whether this will result in an overall aggravation or mitigation of fungal diseases will be determined by the damage potential of the pathogens prevailing under the changed climate. Finally, evolutionary changes and the adaptive potential of plant and pathogen populations might have unexpected consequences on pathosystems (Garrett et al. 2006).

Shifts in future prevalence of the fungal pathogens, as discussed in this analysis, may have consequences for future crop management strategies. A. brassicae outbreaks, which are currently not controlled with fungicides, may require specific treatment under future warming. S. sclerotiorum is currently treated routinely during flowering of oilseed rape, which may not change in the future unless the application of decision support systems for fungicide treatments becomes more widespread amongst farmers. Treatment of P. lingam will remain important under future warming. P. brassicae, which is already addressed by fungicides against $P$. lingam, may not require additional management strategies. Currently no plant protection measures exist against V. longisporum, hence breeding for resistant oilseed rape varieties remains an important target.

\section{Conclusion}

This review showed that there is detailed knowledge available on environmental conditions governing significant life cycle stages of S. sclerotiorum and P. lingam, whereas the knowledge on V. longisporum, P. brassicae and A. brassicae is limited. For example, there are still knowledge gaps in fungal epidemiology concerning the environmental conditions favouring host plant infection by V. longisporum. More research is also needed on S. sclerotiorum with regard to root infection and the early development of apothecia in the field. Research on interacting effects of climatic variables with $\mathrm{CO}_{2}$ and other variables is lacking and thus needed to improve predictions on future prevalence of fungal pathogens. For an improved assessment of the climate change impact on fungal pathogen epidemiology, a four-step concept could be followed:

(1) Existing knowledge gaps identified in this review should be filled by means of target-oriented experiments in controlled environments focussing on impacts of single environmental factors. Different fungal isolates and crop plant cultivars should be included in these experiments to capture the whole possible range of fungal responses to climate.

(2) Knowledge of single factor effects are a prerequisite for experiments looking at combined effects of several climatic factors on both the pathogen and host plant.

(3) This knowledge should be used to create weather-related disease models or to improve existing modelling approaches, linked to climate models.

(4) Studies in controlled environments should be supplemented by field experiments, e.g. located in diverse climate regions which represent potential future climate situations. Experiments should focus on a combination of interacting environmental factors to generate a more realistic assessment of climate change impact as a supplement to disease model outputs.

\section{Acknowledgements}

This work was financially supported by the Ministry for Science and Culture of Lower Saxony, Germany, within the research network "KLIFF - climate change consequences in Lower Saxony". We are grateful to the Max Planck Institute for Meteorology in Hamburg for the supply of REMO data (MPI on behalf of the Umweltbundesamt, 2006) and to Thorsten Zeuner from the Central Institution for Decision Support Systems in Crop Protection, Bad Kreuznach (ZEPP) for providing mesoscale climate projections. Furthermore, we thank Tobias Vogt from the German Weather Service (DWD) for historic weather data.

\section{REFERENCES}

Abawi GS, Grogan RG, 1979. Epidemiology of diseases caused by Sclerotinia species. Phytopathology 69: 899-904.

Analytis S, 1977. Über die Relation zwischen biologischer Entwicklung und Temperatur bei phytopathogenen Pilzen. Journal of Phytopathology 90: 64-76.

Anderson PK, Cunningham AA, Patel NG, Morales FJ, Epstein PR, Daszak P, 2004. Emerging infectious diseases of plants: pathogen pollution, climate change and agrotechnology drivers. Trends in Ecology \& Evolution 19: 535-544.

Anonymus, 2009. Harvest 2009: amounts and prices. Report of the Federal Ministry of Food, Agriculture and Consumer Protection, Bonn, Germany. 
Biddulph JE, Fitt BDL, Leech PK, Welham SJ, Gladders P, 1999. Effects of temperature and wetness duration on infection of oilseed rape leaves by ascospores of Leptosphaeria maculans (stem canker). European Journal of Plant Pathology 105: 769-781.

Boland GJ, Hall R, 1988. Epidemiology of Sclerotinia stem rot of soybean in Ontario. Phytopathology 78: 1241-1245.

Boland GJ, Melzer MS, Hopkin A, Higgins V, Nassuth A, 2004. Climate change and plant diseases in Ontario. Canadian Journal of Plant Pathology 26: 335-350.

Bolton MD, Thomma BPHJ, Nelson BD, 2006. Sclerotinia sclerotiorum (Lib.) de Bary: biology and molecular traits of a cosmopolitan pathogen. Molecular Plant Pathology 7: 1-16.

Bremer H, 2007. Entwicklung einer Herbstprognose für den Erreger der Wurzelhals- und Stängelfaule Phoma lingam (Teleomorph: Leptosphaeria maculans). Gesunde Pflanzen 59 161-169.

Chakraborty S, Datta S, 2003. How will plant pathogens adapt to host plant resistance at elevated $\mathrm{CO}_{2}$ under a changing climate? New Phytologist 159: 733-742.

Chakraborty S, Luck J, Hollaway G, Freeman A, Norton R, Garrett KA, Percy K, Hopkins A, Davis C, Karnosky DF, 2008. Impacts of global change on diseases of agricultural crops and forest trees. CAB Reviews: Perspectives in Agriculture, Veterinary Science, Nutrition and Natural Resources 3: 1-15.

Chakraborty S, Tiedemann AV, Teng PS, 2000. Climate change: potential impact on plant diseases. Environmental Pollution 108 317-326.

Clarkson JP, Staveley J, Phelps K, Young CS, Whipps JM, 2003. Ascospore release and survival in Sclerotinia sclerotiorum. Mycological Research 107: 213-222.

Coakley SM, 1988. Variation in climate and prediction of disease in plants. Annual Review of Phytopathology 26: 163-181.

Coakley S, Scherm H, Chakraborty S, 1999. Climate change and plant disease management. Annual Review of Phytopathology 37: $399-426$.

Coley-Smith JR, Cooke RC, 1971. Survival and germination of fungal sclerotia. Annual Review of Phytopathology 9: 65-92.

Colhoun J, 1973. Effects of environmental factors on plant disease. Annual Review of Phytopathology 11: 343-364.

Daebeler F, Amelung D, Zeise K, 1988. Verticillium-Welke an Winterraps - Auftreten und Bedeutung. Nachrichtenblatt für den Pflanzenschutzdienst in der DDR 42: 71-73.

Daebeler F, Steinbach P, Amelung D, Schulz RR, 1992. Auftreten, Epidemiologie, Bedeutung und Möglichkeiten einer Bekämpfung von Cylinsrosporium concentricum Grev. (Teleomorph: Pyrenopeziza brassicae Sutton et Rawlinson) am Winterraps. Nachrichtenblatt des Deutschen Pflanzenschutzdienstes 44: 109-113.

De Wolf ED, Isard SA, 2007. Disease cycle approach to plant disease prediction. Annual Review of Phytopathology 45: 203-220.

Degenhardt KJ, Petrie GA, Morrall RAA, 1982. Effects of temperature on spore germination and infection of rapeseed by Alternaria brassicae, A. brassicicola and A. raphani. Canadian Journal of Plant Pathology 4: 115-118.

Dixon G, 2009. Plasmodiophora brassicae in its Environment. Journal of Plant Growth Regulation 28: 212-228.

Domsch KH, Gams W, Anderson T-H, 1980. Compendium of Soil Fungi, vol. 1. Academic Press, London, GB.

Donald Z, Czeslaw S, 1998. Effect of temperature on infestation and development of Verticillium dahliae Kleb. on winter oilseed rape. IOBC/wprs Bulletin 21: 41-47.

Dunker S, Keunecke H, Steinbach P, Tiedemann AV, 2008. Impact of Verticillium longisporum on yield and morphology of winter oilseed rape (Brassica napus) in relation to systemic spread in the plant. Journal of Phytopathology 156: 698-707.

Dunker S, Tiedemann AV, 2006. Verticillium longisporum - Eine neue Krankheit im Rapsanbau. Raps 4: 194-197.
Eastburn DM, Degennaro MM, Delucia EH, Dermody O, McElrone AJ, 2010. Elevated atmospheric carbon dioxide and ozone alter soybean diseases in SoyFACE. Global Change Biology 16: $320-330$.

Estrella N, Sparks TH, Menzel A, 2007. Trends and temperature response in the phenology of crops in Germany. Global Change Biology 13: 1737-1747.

Evans N, Gladders P, Fitt BDL, Tiedemann AV, 2009. Altered distribution and life cycles of major pathogens in Europe. In: Feldmann F, Alford DV, Furk C (eds), Crop Plant Resistance to Biotic and Abiotic Factors. Deutsche Phytomedizinische Gesellschaft Braunschweig, Germany, pp. 302-308.

Figueroa L, Fitt BDL, Welham SJ, Shaw MW, McCartney HA, 1995 Early development of light leaf spot (Pyrenopeziza brassicae) on winter oilseed rape (Brassica napus) in relation to temperature and leaf wetness. Plant Pathology 44: 641-654.

Fitt BDL, Brun H, Barbetti MJ, Rimmer SR, 2006a. World-wide importance of Phoma stem canker (Leptosphaeria maculans and L. biglobosa) on oilseed rape (Brassica napus). European Journal of Plant Pathology 114: 3-15.

Fitt BDL, Gladders P, Sutherland KG, Turner JA, Welham SJ, Biddulph JE, Hardwick NV, Wale SJ, 1998. Epidemiology and forecasting of light leaf spot (Pyrenopeziza brassicae) on winter oilseed rape in the UK. IOBC/wprs Bulletin 21: $15-22$.

Fitt BDL, Huang Y-J, Bosch FVD, West JS, 2006b. Coexistence of related pathogen species on arable crops in space and time. Annual Review of Phytopathology 44: 163-182.

Fuhrer J, 2003. Agroecosystem responses to combinations of elevated $\mathrm{CO}_{2}$, ozone, and global climate change. Agriculture, Ecosystems \& Environment 97: 1-20.

Garrett KA, Dendy SP, Frank EE, Rouse MN, Travers SE, 2006 Climate change effects on plant disease: genomes to ecosystems. Annual Review of Phytopathology 44: 489-509.

Ghini R, Hamada E, Bettiol W, 2008. Climatic change and plant diseases. Scientia Agricola 65: 98-107.

Gilles T, Fitt BDL, Kennedy R, Welham SJ, Jeger MJ, 2000. Effects of temperature and wetness duration on conidial infection, latent period and asexual sporulation of Pyrenopeziza brassicae on leaves of oilseed rape. Plant Pathology 49: 498-508.

Goudriaan J, Zadoks JC, 1995. Global climate change: modelling the potential responses of agro-ecosystems with special reference to crop protection. Environmental Pollution 87: 215-224.

Guo XW, Fernando WGD, 2005. Seasonal and diurnal patterns of spore dispersal by Leptosphaeria maculans from canola stubble in relation to environmental conditions. Plant Disease 89: 97-104.

Hall R, 1992. Epidemiology of blackleg of oilseed rape. Canadian Journal of Plant Pathology 14: 46-55.

Hao JJ, Subbarao KV, Duniway JM, 2003. Germination of Sclerotinia minor and S. sclerotiorum sclerotia under various soil moisture and temperature combinations. Phytopathology 93: $443-450$.

Harvell CD, Mitchell CE, Ward JR, Altizer S, Dobson AP, Ostfeld RS, Samuel MD, 2002. Climate warming and disease risks for terrestrial and marine biota. Science 296: 2158-2162.

Heran A, McCartney HA, Li Q 1999. The Effect of Petal Characteristics, Inoculum Density and Environmental Factors on Infection of Oilseed Rape by Sclerotinia sclerotiorum. Proceedings of the 10th International Rapeseed Congress, Canberra, Australia.

Hershman DE, Perkins DM, 1995. Etiology of canola blackleg in Kentucky and seasonal discharge patterns of Leptosphaeria maculans ascospores from infected canola stubble. Plant Disease 79: 1225-1229.

Hibberd JM, Whitbread R, Farrar JF, 1996. Effect of elevated concentrations of $\mathrm{CO}_{2}$ on infection of barley by Erysiph graminis. Physiological and Molecular Plant Pathology 48: 37-53. 
Hong CX, Fitt BDL, 1996. Factors affecting the incubation period of dark leaf and pod spot (Alternaria brassicae) on oilseed rape (Brassica napus). European Journal of Plant Pathology 102: 545-553.

Huang Y-J, Fitt B, Jedryczka M, Dakowska S, West J, Gladders P, Steed J, Li Z-Q 2005. Patterns of ascospore release in relation to phoma stem canker epidemiology in England (Leptosphaeria maculans) and Poland (Leptosphaeria biglobosa). European Journal of Plant Pathology 111: 263-277.

Huang HC, Kozub GC, 1991. Temperature requirements for carpogenic germination of sclerotia of Sclerotinia sclerotiorum isolates of different geographic origin. Botanical Bulletin of Academia Sinica 32: 279-286.

Huang HC, Kozub GC, 1994. Germination of immature and mature sclerotia of Sclerotinia sclerotiorum. Botanical Bulletin of Academia Sinica 35: 243-247.

Huang YJ, Toscano-Underwood C, Fitt BDL, Hu XJ, Hall AM, 2003. Effects of temperature on ascospore germination and penetration of oilseed rape (Brassica napus) leaves by A- or B-group Leptosphaeria maculans (phoma stem canker). Plant Pathology 52: 245-255.

Humpherson-Jones FM, Phelps K, 1989. Climatic factors influencing spore production in Alternaria brassicae and Alternaria brassicicola. Annals of Applied Biology 114: 449-458 (Abstract).

Ioannou N, Schneider RW, Grogan RG, Duniway JM, 1977. Effect of water potential and temperature on growth, sporulation, and production of microsclerotia by Verticillium dahliae. Phytopathology 67: 637-644.

IPCC, 2007. Summary for policymakers. Climate change 2007: impacts, adaptation and vulnerability. In: Parry ML, Canziani OF, Palutikof JP, van der Linden PJ, Hanson CE (eds), Contribution of Working Group II to the Fourth Assessment Report of the Intergovernmental Panel on Climate Change. Cambridge University Press, Cambridge, UK, pp. 7-22.

Jacob D, Podzun R, 1997. Sensitivity studies with the regional climate model REMO. Meteorology and Atmospheric Physics 63: 119-129.

Juroszek P, Tiedemann AV, 2011. Potential strategies and future requirements for plant disease management under a changing climate. Plant Pathology 60: 100-112.

Karapapa VK, Bainbridge BW, Heale JB, 1997. Morphological and molecular characterization of Verticillium longisporum comb. nov. pathogenic to oilseed rape. Mycological Research 101: 1281-1294.

Karl TR, Trenberth KE, 2003. Modern global climate change. Science 302: 1719-1723.

Karolewski Z, Evans N, Fitt BDL, Baierl A, Todd AD, Foster SJ, 2004 Comparative epidemiology of Pyrenopeziza brassicae (light leaf spot) ascospores and conidia from Polish and UK populations. Plant Pathology 53: 29-37.

Karolewski Z, Evans N, Fitt BDL, Todd AD, Baierl A, 2002. Sporulation of Pyrenopeziza brassicae (light leaf spot) on oilseed rape (Brassica napus) leaves inoculated with ascospores or conidia at different temperatures and wetness durations. Plant Pathology 51: 654-665.

Keunecke H, 2009. Einfluss von Kohlfliegenbefall auf die Infektion und Schadwirkung von Verticillium longisporum und Phoma lingam an Raps. Dissertation at the Georg-August-University, Göttingen.

Khangura R, Speijers J, Barbetti MJ, Salam MU, Diggle AJ, 2007. Epidemiology of blackleg (Leptosphaeria maculans) of canola (Brassica napus) in relation to maturation of pseudothecia and discharge of ascospores in Western Australia. Phytopathology 97: 1011-1021.

Koch S, Tiedemann AV, 2005. Den Spritztermin richtig absichern. DLG-Mitteilungen 3: 44-46.

Manning WJ, Tiedemann AV, 1995. Climate change: potential effects of increased atmospheric carbon dioxide $\left(\mathrm{CO}_{2}\right)$, ozone $\left(\mathrm{O}_{3}\right)$, and ultraviolet-B (UV-B) radiation on plant diseases. Environmental Pollution 88: 219-245.
Mridha MAU, Wheeler BEJ, 1993. In vitro effects of temperature and wet periods on infection of oilseed rape by Alternaria brassicae. Plant Pathology 42: 671-675.

Müller M, 2005. Use of fungicides in dependence on disease level and expectation of yield. Gesunde Pflanzen 57: 90-100.

Olesen JE, Bindi M, 2002. Consequences of climate change for European agricultural productivity, land use and policy. European Journal of Agronomy 16: 239-262.

Paul VH, Burhenne S, Günzelmann A, Masuch G, 1990. Zur Bedeutung von Pyrenopeziza brassicae für das Auftreten der Cylindrosporiose im Winterraps in Deutschland. Raps 8: 172-173.

Pegg GF, Brady BL, 2002. Verticillium Wilts. CABI, Wallingford, New York.

Peltonen-Sainio P, Hakala K, Jauhiainen L, Ruosteenoja K, 2009. Comparing regional risks in producing turnip rape and oilseed rape-impacts of climate change and breeding. Acta Agriculturae Scandinavica Section B-Soil and Plant Science 59: 129-138.

Pérès A, Poisson B, Le Sourne V, Maisonneuve C, 1999. Leptosphaeria maculans: effect of temperature, rainfall and humidity on the formation of pseudothecia. Proc. 10th Int. Rapeseed Congress, 1999, Online publication sponsored by The Regional Institute Ltd., NSW, Australia. http://www. regional.org.au/au/gcirc/3/106.htm(accessed 27.05.10).

Roos J, Hopkins R, Kvarnheden A, Dixelius C, 2011. The impact of global warming on plant diseases and insect vectors in Sweden. European Journal of Plant Pathology 129: 9-19.

Rosenzweig C, Iglesias A, Yang XB, Epstein PR, Chivian E, 2001 Climate change and extreme weather events: implications for food production, plant diseases, and pests. Global Change \& Human Health 2: 90-104.

Scherm H, Sutherst RW, Harrington R, Ingram JSI, 2000. Global networking for assessment of impacts of global change on plant pests. Environmental Pollution 108: 333-341.

Scherm H, van Bruggen AHC, 1994. Global warming and nonlinear growth: how important are changes in average temperature? Phytopathology 84: 1380-1384.

Schnathorst WC, 1981. Life cycle and epidemiology of Verticillium. In: Mace ME, Bell AA, Beckman CH (eds), Fungal Wilt Diseases of Plants. Academic Press, NY, USA, pp. 81-111.

Schrödter H, 1965. Methodisches zur Bearbeitung phytometeoropathologischer Untersuchungen, dargestellt am Beispiel der Temperaturrelation. Journal of Phytopathology 53: 154-166.

Seem RC, Magarey RD, Zack JW, Russo JM, 2000. Estimating disease risk at the whole plant level with General Circulation Models. Environmental Pollution 108: 389-395.

Soesanto L, Termorshuizen AJ, 2001. Effect of temperature on the formation of microsclerotia of Verticillium dahliae. Journal of Phytopathology 149: 685-691.

Thürwächter F, Garbe V, Hoppe H-H, 1999. Ascospore discharge, leaf infestation and variations in pathogenicity as criteria to predict Impact of Leptosphaeria maculans on Oilseed Rape. Journal of Phytopathology 147: 215-222.

Tiedemann AV, 1996. Globaler Wandel von Atmosphäre und Klima - welche Folgen ergeben sich für den Pflanzenschutz? Nachrichtenblatt des Deutschen Pflanenschutzdienstes 48: 73-79 (German)

Tiedemann AV, 2004. Aktuelle Krankheiten - Welche Lösungen zeichnen sich ab? Raps 2: 56-59.

Tiedemann AV, Ulber B, 2008. Verändertes Auftreten von Krankheiten und Schädlingen durch Klimaschwankungen. In: Tiedemann AV, Heitefuss R, Feldmann F (eds), Pflanzenproduktion im Wandel Wandel im Pflanzenschutz. Deutsche Phytomedizinische Gesellschaft, Braunschweig, Germany, pp. 79-89.

Travadon R, Bousset L, Saint-Jean S, Brun H, Sache I, 2007. Splash dispersal of Leptosphaeria maculans pycnidiospores and the spread of blackleg on oilseed rape. Plant Pathology 56: 595-603. 
Tubiello FN, Soussana JF, Howden SM, 2007. Crop and pasture response to climate change. Proceedings of the National Academy of Sciences 104: 19686-19690.

Tuck G, Glendining MJ, Smith P, House JI, Wattenbach M, 2006. The potential distribution of bioenergy crops in Europe under present and future climate. Biomass and Bioenergy 30: 183-197. Weigel HJ, 2005. Gesunde Pflanzen unter zukünftigem Klima. Gesunde Pflanzen 57: 6-17.

Werner P, Gerstengarbe FW, 2007. Welche Klimaänderungen sind in Deutschland zu erwarten? In: Endlicher W, Gerstengarbe FW (eds), Der Klimawandel - Einblicke, Rückblicke und Ausblicke. Deutsche Gesellschaft für Geographie Potsdam, Germany, pp. 56-59.

Willetts HJ, Wong JAL, Kirst GD, 1980. The biology of Sclerotinia sclerotiorum, S. trifoliorum, and S. minor with emphasis on specific nomenclature. Botanical Review 46: 101-165.
Wu BM, Subbarao KV, 2008. Effects of soil temperature, moisture, and burial depths on carpogenic germination of Sclerotinia sclerotiorum and S. minor. Phytopathology 98: 1144-1152. Young CS, Clarkson JP, Smith JA, Watling M, Phelps K, Whipps JM, 2004. Environmental conditions influencing Sclerotinia sclerotiorum infection and disease development in lettuce. Plant Pathology 53: 387-397.

Zeise K, Seidel D, 1990. Zur Entwicklung und Schadwirkung der Verticillium-Welkekrankheit am Winterraps. Raps 8: 20-22. Zeise K, Steinbach P, 2004. Schwarze Rapswurzeln und der Vormarsch der Verticillium-Rapswelke. Raps 4: 170-174.

Zhang Y, Chen W, Smith SL, Riseborough DW, Josef Cihlar J, 2005. Soil temperature in Canada during the twentieth century: complex responses to atmospheric climate change. Journal of Geophysical Research 110. doi:10.1029/2004JD004910. D03112. 


\title{
Chapter 3:
}

\section{Application of a robust experimental method to study soil warming effects on oilseed rape}

\author{
Magdalena Siebold*, Andreas von Tiedemann
}

University of Göttingen, Department of Crop Sciences, Division of Plant Pathology and Crop Protection, Grisebachstr. 6, D-37077 Göttingen, Germany

\section{A R T I C L E I N F O}

Article history:

Received 10 January 201

Received in revised form 4 May 2012

Accepted 8 May 2012

\section{Keywords:}

Winter oilseed rape

Brassica napus

Soil warming experi

Soil warming experiment

Soil temperature

Phenology

\begin{abstract}
A B S T R A C T
Climate change is expected to cause a mean annual temperature increase in Germany of up to $4{ }^{\circ} \mathrm{Cby} 2100$. Hence, field manipulation experiments for the assessment of the impact of global warming on agricultural production are needed to supplement existing modeling approaches. Here, we present a soil warming facility adapted for field crops, enabling common agronomic practices, including soil tillage, to be carried out while simulating natural warming scenarios. The experimental setup consists of buried heating cables and a fully computerized temperature control and data logging system. Treatments reflected medium(up to 2050) and long-term (up to 2100) climate warming scenarios compared to the unheated (ambient) control. In a year-round experiment, there were no technical problems and the programmed temperature offset was kept stable at two levels, $+1.6^{\circ} \mathrm{C}\left( \pm 0.17^{\circ} \mathrm{C}\right)$ or $+3.2^{\circ} \mathrm{C}\left( \pm 0.27^{\circ} \mathrm{C}\right)$ above ambient throughout the experiment. We assessed warming effects on the plot microclimate as well as on biological parameters in a winter oilseed rape crop (Brassica napus L.). Growth stages were advanced in October and April, and plant length before flowering was significantly higher in the warmest treatment compared to the unheated control plots. Overall, our method proved stable and reliable under field conditions enabling common agronomic practices to be carried out while observing the effects of increased soil temperatures.
\end{abstract}

() 2012 Elsevier B.V. All rights reserved.

\section{Introduction}

Climate change has led to an increase in mean air temperatures in northern Germany over the last 50 years (Haberlandt et al., 2010). This trend is likely to continue, with temperatures expected to reach $+2{ }^{\circ} \mathrm{C}$ by 2050 and up to $+4^{\circ} \mathrm{C}$ by 2100 compared to the baseline period 1961-1990 (Jacob and Podzun, 1997; Werner and Gerstengarbe, 2007). This increase may lead not only to shifts of agro-climatic zones and a changing phenology of crops in existing production zones (Chakraborty et al., 2000; Peltonen-Sainio et al., 2009; Tuck et al., 2006; Weigel, 2005), but also to changes in soil properties (Jones et al., 2009). Experiments focusing on the effects of rising soil temperatures on agricultural crops on a regional scale, however, have received little attention so far. For example, Stone et al. (1999) used plastic covers to simulate warming effects on a maize crop, and heating cables in the soil (Hantschel et al., 1995; Patil et al., 2010) or on the soil surface (Kamp et al., 1998; Xiao et al., 2010) have been used in winter wheat. A comparative assessment of different experimental approaches, both

\footnotetext{
* Corresponding author. Tel.: +4955139 14090; fax: +49551393706 E-mail address: msiebol@gwdg.de (M. Siebold).
}

above- and below-ground, used to study warming effects on plants and microorganisms under field conditions, has been published recently (Aronson and McNulty, 2009). By applying a soil warming method, a stable soil temperature offset between ambient and heated plots can be maintained throughout the year. Heating cables are relatively cheap and robust during the season with regard to growing vegetation cover and possible disturbances in the soil. Furthermore, soil warming effects can be studied with other conditions unchanged and without influencing the above-ground crop microclimate, although soil moisture remains a dependent variable which will be affected simultaneously.

In this paper, we describe the optimization and first application of an experimental setup containing heating cables to study warming effects on oilseed rape (Brassica napus L.), the most important crop for edible oil, fodder and bio-fuel production in Europe. Different and sometimes contrasting results with respect to cable depth, cable spacing, power intensity and other parameters have been published previously (Hillier et al., 1994; Peterjohn et al., 1993). Hence, prior to our experiment we conducted a pilot study to determine the most appropriate setup. The focus of this study lies on elevated soil temperatures as a result of rising air temperatures, which are predicted with current climate change simulation models (Christensen and Christensen, 2007; Karl and Trenberth, 2003). 
Table 1

Summary of the parameters tested in the pilot study prior to the soil warming experiment.

\begin{tabular}{|c|c|c|c|c|c|c|c|c|c|}
\hline \multirow[t]{2}{*}{ Exp. } & \multirow[t]{2}{*}{$\begin{array}{l}\text { Cable } \\
\text { depth }(\mathrm{cm})\end{array}$} & \multirow{2}{*}{$\begin{array}{l}\text { Cable } \\
\text { spacing } \\
(\mathrm{cm})\end{array}$} & \multirow[t]{2}{*}{$\begin{array}{l}\text { Power density } \\
\left(\mathrm{W} \mathrm{m}^{-2}\right)\end{array}$} & \multirow{2}{*}{$\begin{array}{l}\text { Placement of } \\
\text { control } \\
\text { thermistor }^{\mathrm{a}}\end{array}$} & \multicolumn{4}{|c|}{$\begin{array}{l}\text { Mean variation from fixed target } \\
\text { temperature }\left(11^{\circ} \mathrm{C}\right)\end{array}$} & \multirow{2}{*}{$\begin{array}{l}\text { Average vertical } \\
\text { temp. gradient in } \\
\text { the soil profile }\left({ }^{\circ} \mathrm{C}\right)\end{array}$} \\
\hline & & & & & $\begin{array}{l}\text { Above } \\
\text { cables }\end{array}$ & $\begin{array}{l}\text { Between } \\
\text { cables }\end{array}$ & At cable & $\begin{array}{l}\text { Below } \\
\text { cables }\end{array}$ & \\
\hline 1 & 5 & 5 & 600 & 1 & -3.4 & -0.1 & 0.7 & 1.2 & 4.6 \\
\hline 2 & 5 & 5 & 600 & 2 & -2.6 & -0.1 & 1.1 & 0.9 & 3.7 \\
\hline 3 & 5 & 5 & 600 & 3 & -1.5 & 1.7 & 0.7 & 1.0 & 3.2 \\
\hline 4 & 5 & 5 & 600 & 4 & -2.4 & 0.5 & 1.3 & 1.0 & 3.7 \\
\hline 5 & 10 & 5 & 600 & 3 & 1.2 & 2.8 & 6.1 & 2.2 & 4.8 \\
\hline 6 & 5 & 10 & 300 & 3 & 0.2 & 3.8 & 15.4 & 2.0 & 15.2 \\
\hline
\end{tabular}

a Placement of control thermistors: 1 , at heating cable; 2 , between cables; $3,5 \mathrm{~cm}$ above cables; $4,5 \mathrm{~cm}$ below cables.

\section{Materials and methods}

\subsection{Pilot study}

The pilot study was carried out in an unheated greenhouse. Four hundred liters of silty compost soil in a plastic container $(116 \mathrm{~cm} \times 80 \mathrm{~cm} \times 60 \mathrm{~cm})$ were warmed using a heating cable (domoteck $\mathrm{GmbH}$, Heppenheim, Germany) with $30 \mathrm{~W} \mathrm{~m}^{-1}$, reaching $300 \mathrm{Wm}^{-2}$ at $10 \mathrm{~cm}$ cable spacing and $600 \mathrm{Wm}^{-2}$ at $5 \mathrm{~cm}$ spacing (Fig. 1). A simplified temperature control was installed using a universal thermostat (Conrad Electronic SE, Hirschau, Germany) including a sensor set to a fixed target temperature of $11^{\circ} \mathrm{C}$. Soil temperatures were monitored at different places in the container for the different experimental settings (Table 1) using two pT100 temperature probes and a CLog Datalogger (UP GmbH Ibbenbüren, Germany). Soil water content was measured and kept at -100 to $-150 \mathrm{kPa}$ using a Watermark sensor connected to a data reader. The variation of settings included cable spacing $(5 \mathrm{~cm}$ and $10 \mathrm{~cm})$, cable depth $(5,10,15$ and $20 \mathrm{~cm})$ and placement of the temperature control thermistor (adjacent to the cable, between cables, $5 \mathrm{~cm}$ above cables and $5 \mathrm{~cm}$ below cables). Each setup was tested for the duration of $24-36 \mathrm{~h}$.

\subsection{Experimental site}

The experimental site is located in the northern part of Göttingen, Lower Saxony, Germany $\left(51^{\circ} 33^{\prime} 29.28^{\prime \prime} \mathrm{N}, 9^{\circ} 55^{\prime} 59.46^{\prime \prime} \mathrm{E}\right.$ WGS84). Annual mean temperature and precipitation in Göttingen were $9.5^{\circ} \mathrm{C}$ and $712 \mathrm{~mm}$, respectively, during the period

\section{container}

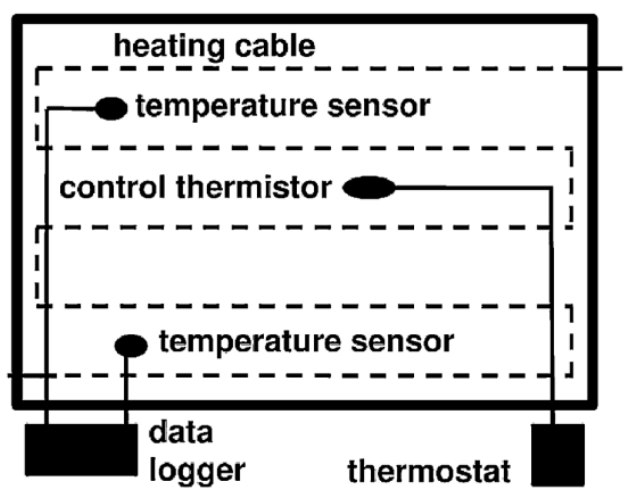

Fig. 1. Experimental setup of the pilot study conducted in a 4001 container with silty compost in an unheated greenhouse. Spacing and burial depth of the heating cable as well as the placement of the control thermistor were varied.
2000-2009. The site was selected due to its close proximity to the institute, enabling power supply and direct data transfer by linking to the university intranet. The original stony and heterogeneous soil was replaced to a depth of $1 \mathrm{~m}$ by top soil from a nearby field (high silty clay (Tu4), pH 8.3). The soil was left to settle for 11 months before the start of the experiment.

\subsection{Experimental design}

The experimental site consists of 12 plots, each $2 \mathrm{~m}$ by $2.5 \mathrm{~m}$ in size. Spacing between plots was $50 \mathrm{~cm}$ in order to minimize heat transfer between plots. The total size of the experimental field was $60 \mathrm{~m}^{2}$ and plots were arranged in two rows (Fig. 2). Heating cables (A. Rak Wärmetechnik GmbH, Frankfurt, Germany) with a length of $100 \mathrm{~m}$ and a power consumption of $500 \mathrm{~W}$ were buried in each of the 12 plots at a depth of $10 \mathrm{~cm}$ in a parallel pattern with a spacing of $5 \mathrm{~cm}$, thus reaching a power density of $100 \mathrm{~W} \mathrm{~m}^{-2}$. The cables with a diameter of $5 \mathrm{~mm}$ consisted of a seven-stranded wire surrounded by several layers of plastic materials and braid operating at $230 \mathrm{~V}$. Heating cables were also installed in control plots to ensure equal physical conditions in the plots. Heating treatments included (1) ambient soil temperature, (2) ambient $+2{ }^{\circ} \mathrm{C}$ and (3) ambient $+4{ }^{\circ} \mathrm{C}$, the latter resembling warming scenarios for Lower Saxony by 2050 (medium-term) and 2100 (long-term), respectively. All treatments were repeated four times in a randomized block design. After 1 month, soil temperature offsets were reduced to $+1.6^{\circ} \mathrm{C}$ and $+3.2^{\circ} \mathrm{C}$, respectively, when the readings indicated a higher than expected accuracy of temperature control (for convenience, plots are henceforth labeled $+2{ }^{\circ} \mathrm{C}$ plots and $+4{ }^{\circ} \mathrm{C}$ plots throughout the paper). The soil warming experiment was started on 25 August 2010 and ran throughout the following 11 months.

\subsection{Measurement of climate parameters}

Each of the 12 plots was equipped with eight pT100 soil temperature sensors (Steffen Messtechnik, Dorsten, Germany). These were operated in a three conductor circuit in order to minimize false measurements due to the long connecting cables used. Four of the eight sensors per plot were placed at $5 \mathrm{~cm}$ soil depth and the remaining four at $15 \mathrm{~cm}$. To prevent movement of the sensors due to soil tillage, they were fixed on plastic sticks, each stick fixing a sensor at $5 \mathrm{~cm}$ and $15 \mathrm{~cm}$ depth. Sticks were placed vertically into the soil and randomly distributed across the plots. The mean value of the four sensors at one depth was calculated and logged. Temperature control in the experimental plots was conducted according to the mean values measured by sensors at $15 \mathrm{~cm}$ depth which produced more stable courses of temperature. Additionally, each plot was equipped with two Frequency Domain Reflectometry soil moisture sensors (10HS FD, Decagon Devices, Inc., Pullman WA, USA) buried horizontally in $5-10 \mathrm{~cm}$ soil depth and measuring volumetric water content across a $10 \mathrm{~cm}$ 


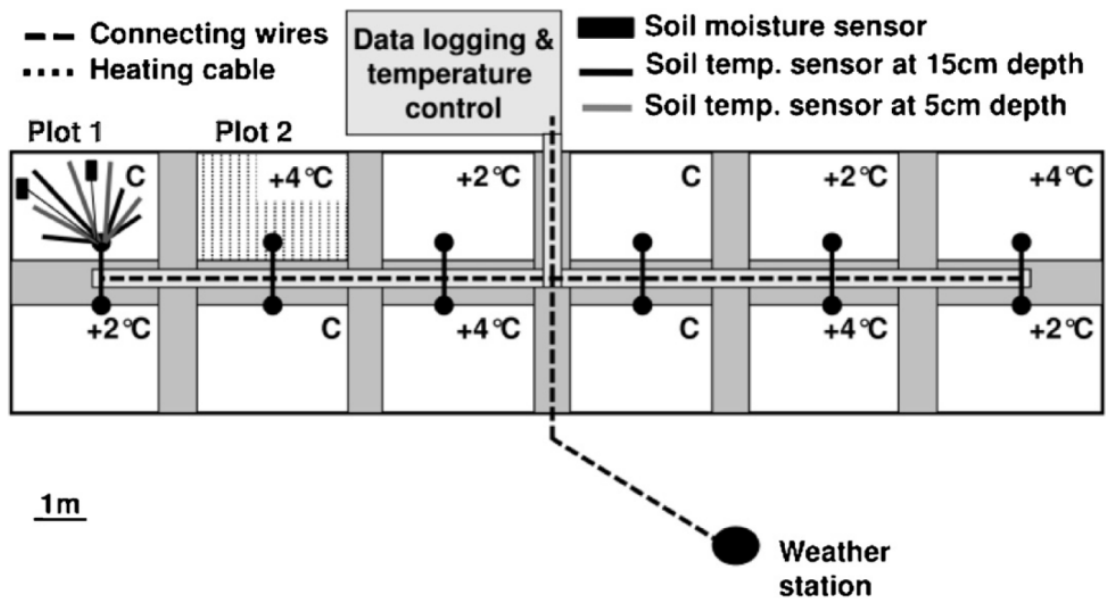

Fig. 2. Layout of the experimental site and arrangement of the heating treatments. Plot 1 shows the number and distribution of sensors and Plot 2 the arrangement of heating cables used in all plots ( $\mathrm{C}$, control plot; $+2{ }^{\circ} \mathrm{C}$ and $+4{ }^{\circ} \mathrm{C}$, heated plots).

distance in the soil. Above-ground weather parameters including air temperature, relative humidity, precipitation, global radiation and wind speed were recorded by a weather station (Lambrecht $\mathrm{GmbH}, \mathrm{Göttingen,} \mathrm{Germany)} \mathrm{installed} \mathrm{next} \mathrm{to} \mathrm{the} \mathrm{experimental} \mathrm{site.}$ Details on type, measuring range, accuracy and sensitivity of all sensors are summarized in Table 2 .

\subsection{Infrastructure}

All sensor cables as well as the heating cable from each plot were connected above-ground in a junction box located next to each plot, and from there distributed to the control unit placed in an aluminum container besides the field. The air-conditioned control unit (Rittal GmbH \& Co. KG, Herborn, Germany) contained the temperature control and data logging system, a cutout switch, the actuation of the heating cables and an industrial Ethernet switch.

\subsection{Climate data logging and temperature control}

The temperature control and data logging system consists of three Mini8 ${ }^{\mathrm{TM}}$ multichannel PID controllers (Eurotherm Germany GmbH, Limburg, Germany). All below- and above-ground parameters were recorded at $10-\mathrm{min}$ intervals. Graphical visualization was performed with the Eycon 20 software (Eurotherm Germany $\mathrm{GmbH}$, Limburg, Germany). The operating interface consists of a matrix touch screen display which was used for configuration of the plot functions (control or control plus offset), programming of the target temperature (target temperature plot $\mathrm{B}=$ actual temperature in control plot + offset plot B) and display of online trends of all process data. Data were stored in ASCII files via a $46 \mathrm{MB}$

Table 2

Details on the sensors used in this experiment.

\begin{tabular}{|c|c|c|c|c|}
\hline Parameter & Sensor type & Company & Accuracy & Range \\
\hline Soil temperature & pT100 & Steffen Messtechnik, Dorsten, Germany & $\pm 0.1 \mathrm{C}$ at $0{ }^{\circ} \mathrm{C}$ & -50 to $+85^{\circ} \mathrm{C}$ \\
\hline Soil moisture & $10 \mathrm{HS}$ FD & Decagon Devices Inc., Pullman WA, USA & $\pm 2 \%$ & $0-57 \%$ VWC \\
\hline Global radiation & Pyranometer 16103.3 & Lambrecht GmbH, Göttingen, Germany & $\pm 0.1 \%$ at $20^{\circ} \mathrm{C}, \pm 0.5 \%$ at -30 to $70^{\circ} \mathrm{C}$ & $0-2000 \mathrm{Wm}^{-2}$ \\
\hline Wind speed & INDUSTRY 14577 & Lambrecht GmbH, Göttingen, Germany & $< \pm 2 \%$ & $0-50 \mathrm{~m} \mathrm{~s}^{-1}$ \\
\hline Air temperature & pT100, 8093.1, combined & Lambrecht GmbH, Göttingen, Germany & $\pm 0.2^{\circ} \mathrm{C}$ at -27 to $+70^{\circ} \mathrm{C}$ & -30 to $+70^{\circ} \mathrm{C}$ \\
\hline Relative humidity & 8093.1, combined & Lambrecht GmbH, Göttingen, Germany & $\pm 2 \%$ at $5.95 \%$ r.H. and +10 to $+40^{\circ} \mathrm{C}$ & $0-100 \%$ r.H. \\
\hline Precipitation & After Joss-Tognini, $15189 \mathrm{H}$ & Lambrecht GmbH, Göttingen, Germany & 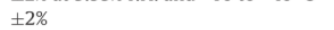 & $0-8 \mathrm{~mm} \mathrm{~min}^{-1}$ \\
\hline
\end{tabular}

ring store and transferred once a day to the institute server via FTP in order to be accessible from the office PCs. This data logging and visualization system enabled daily access to weather data both from the office and on the display next to the experimental site.

\subsection{Crop management}

Before sowing, a rabbit-proof fence was built around the experimental area in order to protect young plants. Weeds were removed by pre-sowing treatment with glyphosate and post-emergence weeding by hand during the course of the experiment. Two varieties of winter oilseed rape, Falcon (NPZ Hohenlieth, Germany) and SEM 05-500256 (SW Seed, Sweden; abbreviated to SEM throughout the paper), were sown by hand in a split plot design on 25 August 2010 with a distance of $14 \mathrm{~cm}$ between rows and $7 \mathrm{~cm}$ within rows, resulting in a seeding density of 70 seeds $/ \mathrm{m}^{2}$. Fertilizers and growth regulators were applied according to common agricultural practice. No fungicides were applied, and insecticides were kept to a minimum in order to observe warming effects on insect pests and fungal diseases (data not shown).

\subsection{Biological measurements}

Plant growth stage (BBCH, Lancashire et al., 1991) and plant length were assessed on a two-weekly basis during the growing season, as well as the degree of plant coverage (\%) according to Braun-Blanquet (1964) in the fall. Stem base diameter of five plants per plot was measured at five time points from mid-April at 3-week intervals. 


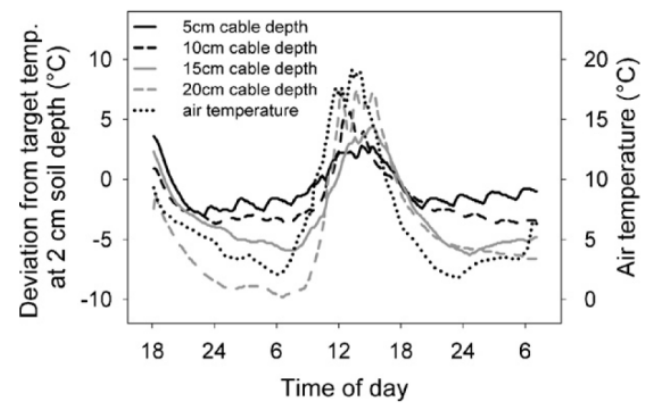

Fig. 3. Deviation from the fixed target temperature of $11^{\circ} \mathrm{C}$ at $2 \mathrm{~cm}$ soil depth (close to the soil surface) with heating cables and control thermistors placed at different soil depths (pilot study in the unheated greenhouse). Cable spacing was $5 \mathrm{~cm}$. Control thermistors were placed between the heating cables.

\subsection{Statistics}

Data were analyzed using STATISTICA v. 9.1 (StatSoft, Inc., Tulsa, OK, USA). We applied two-way ANOVA and multi-comparison by Tukey's HSD (honestly significant difference) test to analyze for main effects of treatment factors (temperature level and variety, with their interaction) on the dependent biological parameters growth stage, plant length, degree of plant coverage and stem base diameter separately for each sampling date. One-way ANOVA and Tukey's HSD were used to assess the significance of differences in frost hours, annual mean soil temperature and soil moisture as well as soil temperature sums at different soil depths due to the three temperature regimes. Pearson product-moment correlation coefficients or Spearman rank correlation coefficients $\left(r_{\mathrm{s}}\right)$ were calculated to establish relationships between above-ground and below-ground weather data as well as growth stage and temperature sums at different sampling time points. For all analyses, $P$-values $\leq 0.05$ were considered significant. Descriptive statistics were used to assess the quality of the heating method.

\section{Results}

\subsection{Pilot study}

Although we used a fixed target temperature rather than a reference temperature from an unheated control plot in the pilot study, valuable conclusions for the field experiment could be drawn. The thermal energy provided by the cables was distributed both upward and downward in the soil. During the night, deeper layers were warmer than layers close to the surface, matching the natural temperature gradient in soils. Heating lead to rapid warming and cooling processes in the soil. The wider the cable spacing and the more distant the control thermistor was from the heating cables, the slower temperature control took place.

The heating effect in the upper soil layer declined with increasing burial depth of the heating cables and control thermistor (Fig. 3). At $5 \mathrm{~cm}$ cable depth, temperatures near the soil surface were mainly influenced by the heating with a mean deviation from the target temperature of $-0.8^{\circ} \mathrm{C}$. At $10 \mathrm{~cm}$ cable depth, temperatures near the soil surface were influenced by both heating, especially during the night, and air temperature (mean deviation from target temperature $-1.8^{\circ} \mathrm{C}$ ). At 15 and particularly at $20 \mathrm{~cm}$ cable depth, however, deviation from the target temperature near the soil surface was high (on average $-3.0^{\circ} \mathrm{C}$ and $-4.5^{\circ} \mathrm{C}$, respectively), even during the night, and soil temperature cycles near the soil surface resembled more closely the diurnal course of air temperature. Hence, we

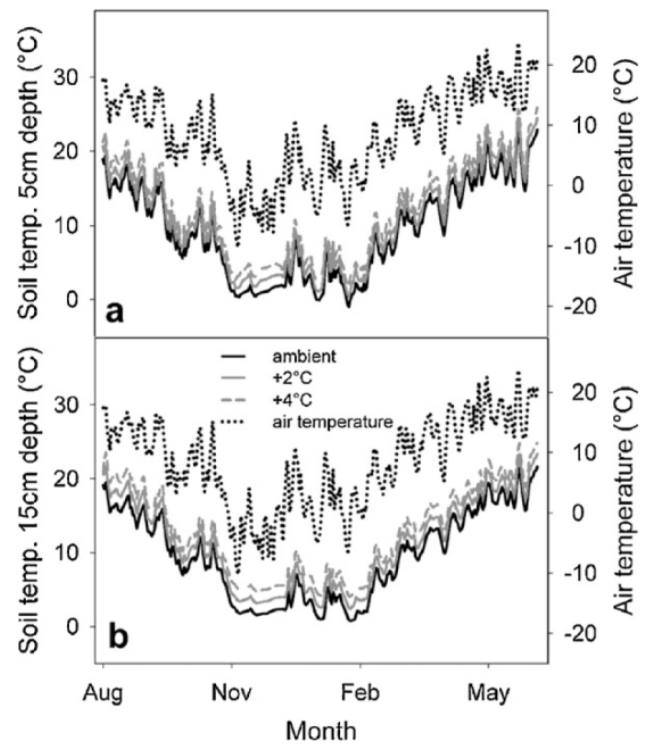

Fig. 4. Soil temperatures at $5 \mathrm{~cm}$ (a) and $15 \mathrm{~cm}$ (b) depth in the three warming treatments in the field experiment compared with air temperature based on daily mean temperatures.

tested further experimental setups only with 5 and $10 \mathrm{~cm}$ cable depths.

A comparison of the different settings (Table 1) shows that experiments 1-4 failed to reach the required temperature offset close to the soil surface. At $10 \mathrm{~cm}$ cable depth (Experiment 5 ), warmth reached all soil layers, without leading to drastic over-heating of the near-cable area. A cable spacing of $10 \mathrm{~cm}$ in experiment 6 resulted in unacceptable overheating near the cables for periods of up to $6 \mathrm{~h}$ and an unnatural vertical temperature gradient of $15.2^{\circ} \mathrm{C}$. By choosing a cable depth of $10 \mathrm{~cm}$, cable spacing of $5 \mathrm{~cm}$ and placement of control thermistors $5 \mathrm{~cm}$ below the heating cables in the actual field experiment, we prevented overheating and ensured that the target temperature was reached in adjacent soil compartments, particularly close to the soil surface.

\subsection{Operation and performance of the field heating system}

Throughout the year-round experiment from 25 August 2010 until 12 July 2011, the system ran without a single technical interruption. After the start of the experiment on the day of sowing, the programmed temperature offsets of $+2{ }^{\circ} \mathrm{C}$ and $+4{ }^{\circ} \mathrm{C}$ were reached on average after 7 and $13 \mathrm{~h}$ at $15 \mathrm{~cm}$ depth, respectively. At $5 \mathrm{~cm}$ depth, these offsets were reached slightly earlier (after 6 and $10 \mathrm{~h}$, respectively). Due to the unexpected stability and accuracy of the temperature offsets, they were reprogrammed at $+1.6^{\circ} \mathrm{C}$ and $+3.2^{\circ} \mathrm{C}$ after 1 month of the experiment in order to represent a more realistic warming scenario for the upper soil layer.

Differences in annual mean temperature at $5 \mathrm{~cm}$ depth were $1.4^{\circ} \mathrm{C}\left( \pm 0.32^{\circ} \mathrm{C}\right)$ and $2.8^{\circ} \mathrm{C}\left( \pm 0.43^{\circ} \mathrm{C}\right)$, whereas at $15 \mathrm{~cm}$ depth the mean temperature differences were $1.7^{\circ} \mathrm{C}\left( \pm 0.17^{\circ} \mathrm{C}\right)$ and $3.3^{\circ} \mathrm{C}$ $\left( \pm 0.27^{\circ} \mathrm{C}\right)$ between control plots and $+2{ }^{\circ} \mathrm{C}$ and $+4{ }^{\circ} \mathrm{C}$ plots, respectively (Fig. 4). The deviation of the soil temperature from the target temperature in both warming treatments and both soil depth is shown in Fig. 5 . At $15 \mathrm{~cm}$ soil depth, deviation from the target temperature was low, whereas at $5 \mathrm{~cm}$ soil depth the soil temperature was often below the target temperature and resembled more patterns of air temperature changes. Observations after harvest using 


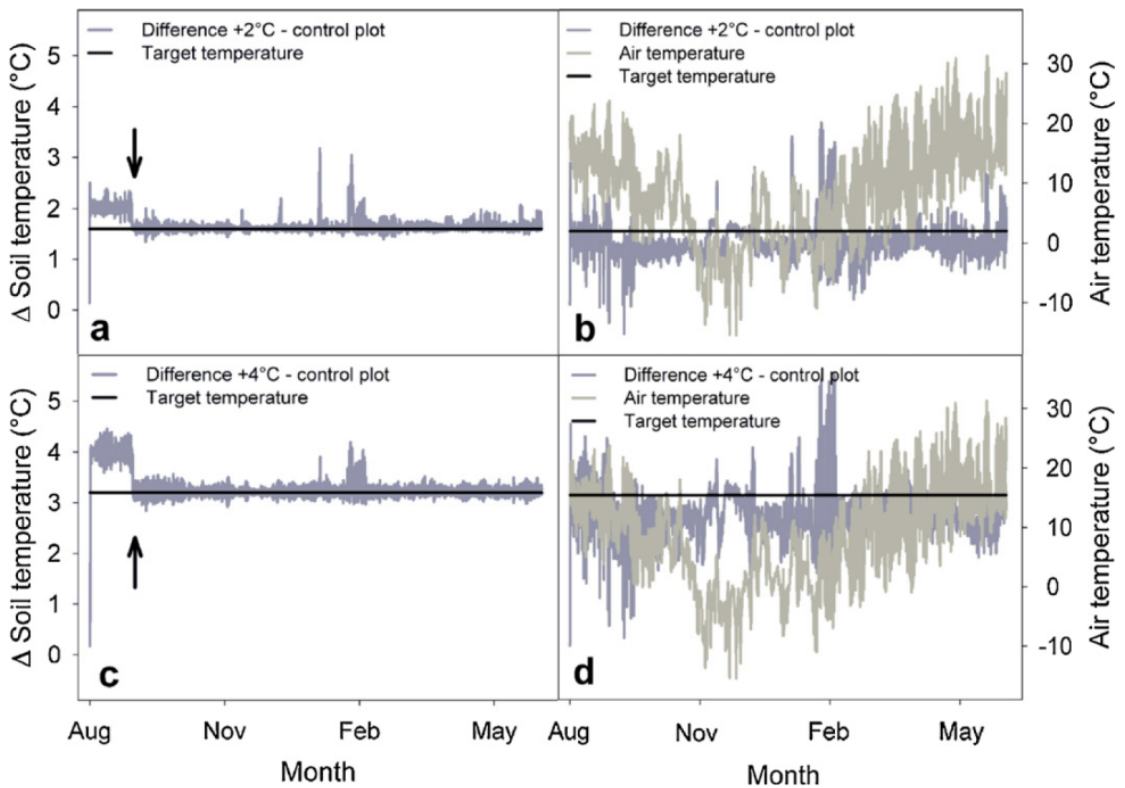

Fig. 5. Deviation of soil temperature from the target value in the $+2{ }^{\circ} \mathrm{C}$ plot at $15 \mathrm{~cm}$ (a) and $5 \mathrm{~cm}$ soil depth (b) and in the $+4{ }^{\circ} \mathrm{C}$ plot at $15 \mathrm{~cm}$ (c) and $5 \mathrm{~cm}$ soil depth (d), based on hourly mean temperatures. The reprogramming of the target values after 1 month to $+1.6^{\circ} \mathrm{C}$ and $+3.2^{\circ} \mathrm{C}$ is indicated by an arrow in (a) and (c).

an infrared camera revealed differences in soil surface temperature during day and night when no plant cover was present. In full sunshine (16 July 2011, 16:00) with high radiation no differences between treatments were visible (Fig. 6a). At night (19 July 2011 22:00), however, soil surface temperature differences were measurable, following the programmed temperature offset at $15 \mathrm{~cm}$ depth with high accuracy (Fig. 6b)

\subsection{Heating effects on the soil microclimate}

The soil microclimate of the plots was influenced by the different warming treatments in several ways (Table 3). The three treatments differed significantly from each other in terms of mean annual soil temperature at $15 \mathrm{~cm}$ and $5 \mathrm{~cm}$ depth as well as the temperature sums at both depths at three different time points (5 September 2010, 13 April 2011 and 15 June 2011). The average vertical soil temperature profile in the heated plots was similar to the control plots: the annual mean soil temperature at $15 \mathrm{~cm}$ depth was $0.3^{\circ} \mathrm{C}$ higher than at $5 \mathrm{~cm}$ depth in the control plots, whereas in $+2{ }^{\circ} \mathrm{C}$ and
$+4{ }^{\circ} \mathrm{C}$ plots differences of $0.6^{\circ} \mathrm{C}$ and $0.8^{\circ} \mathrm{C}$ occurred between $15 \mathrm{~cm}$ and $5 \mathrm{~cm}$ depth, respectively.

The highest and lowest temperatures, $45.2{ }^{\circ} \mathrm{C}$ and $-3.5^{\circ} \mathrm{C}$, were both measured at $5 \mathrm{~cm}$ depth in a control plot. At $15 \mathrm{~cm}$ soil depth, extreme soil temperatures ranged from $36.8^{\circ} \mathrm{C}$ in a $+4^{\circ} \mathrm{C}$ plot and $0.5^{\circ} \mathrm{C}$ in a control plot. The number of frost hours (soil temperature at or below $0^{\circ} \mathrm{C}$ ) at $5 \mathrm{~cm}$ depth was significantly reduced in the heated plots in comparison to the control plots, but the two heated treatments were not significantly different from each other. At $15 \mathrm{~cm}$ soil depth, temperatures below $0{ }^{\circ} \mathrm{C}$ were never recorded.

The mean annual soil moisture in the upper $15 \mathrm{~cm}$ soil layer was slightly reduced in the heated plots compared to the control plots. Although differences were measurable for shorter time periods, especially in the fall (Fig. 7), reduction of soil moisture was not significant, at least when considering annual mean values of the different heating treatments. Soil moisture was usually elevated after rain events, especially in the fall. In winter, snow cover duration was reduced in the heated plots and the three treatments were distinguishable by the patchiness of the snow cover.
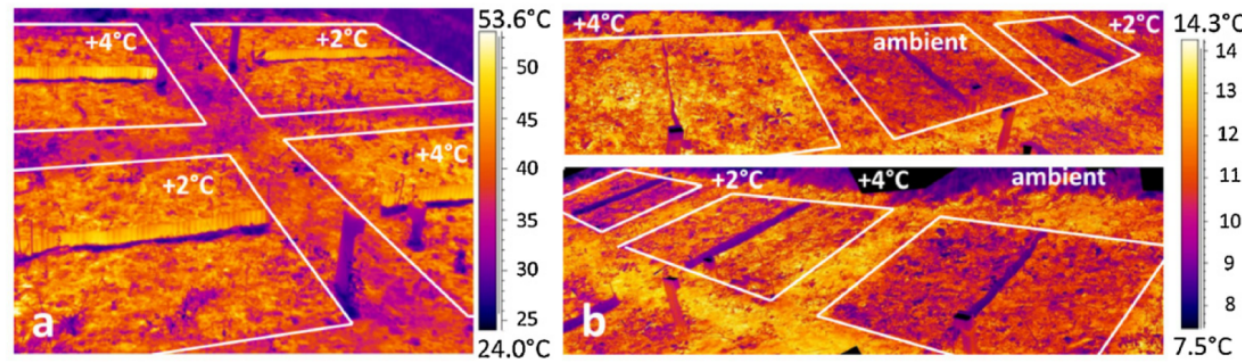

Fig. 6. Heat radiation of plots during the day (16 July 2011, 16:00, a) and during the night (19 July 2011, 22:00, b) without plant cover after harvest. Photos were taken with an infrared camera and analyzed using the ThermaCAM Researcher Pro 2.10 software. 
Table 3

Soil temperature, soil moisture, frost hours and temperature sums in the three warming treatments in the field experiment for the period from 25 August 2010 to 12 July 2011.

\begin{tabular}{|c|c|c|c|}
\hline \multirow[t]{2}{*}{ Parameter } & \multicolumn{3}{|c|}{ Warming treatment } \\
\hline & Ambient & $+2{ }^{\circ} \mathrm{C}$ & $+4^{\circ} \mathrm{C}$ \\
\hline Mean annual soil temp. $15 \mathrm{~cm}$ & $9.6^{a} \pm 0.3$ & $11.3^{b} \pm 0.3$ & $12.9^{c} \pm 0.3$ \\
\hline Mean annual soil temp. $5 \mathrm{~cm}$ & $9.3^{\mathrm{a}} \pm 0.3$ & $10.7^{b} \pm 0.2$ & $12.1^{\mathrm{c}} \pm 0.1$ \\
\hline Soil temp. sum at $15 \mathrm{~cm}$ on $5 \mathrm{Sept}$ & $204.6^{\mathrm{a}} \pm 2.5$ & $228.4^{b} \pm 2.3$ & $250.6^{c} \pm 2.2$ \\
\hline Soil temp. sum at $15 \mathrm{~cm}$ on $13 \mathrm{Apr}$ & $1685.9^{\mathrm{a}} \pm 48$ & $2079.1^{\mathrm{b}} \pm 49$ & $2457.4^{\mathrm{c}} \pm 47$ \\
\hline Soil temp. sum at $15 \mathrm{~cm}$ on 15 Jun & $2586.3^{\mathrm{a}} \pm 79$ & $3082.9^{b} \pm 81$ & $3560.9^{c} \pm 78$ \\
\hline Soil temp. sum at $5 \mathrm{~cm}$ on $5 \mathrm{Sept}$ & $195.7^{\mathrm{a}} \pm 2.7$ & $214.5^{b} \pm 2.2$ & $233.3^{c} \pm 3.9$ \\
\hline Soil temp. sum at $5 \mathrm{~cm}$ on $13 \mathrm{Apr}$ & $1571.8^{\mathrm{a}} \pm 44$ & $1890.2^{b} \pm 18$ & $2223.9^{c} \pm 25$ \\
\hline Soil temp. sum at $5 \mathrm{~cm}$ on 15 Jun & $2493.5^{\mathrm{a}} \pm 79$ & $2901.8^{\mathrm{b}} \pm 47$ & $3328.8^{c} \pm 26$ \\
\hline Mean annual soil moisture & $29.0^{\mathrm{a}} \pm 0.7$ & $28.5^{a} \pm 0.7$ & $28.2^{\mathrm{a}} \pm 1.6$ \\
\hline Frost hours at $5 \mathrm{~cm}$ depth & $116.5^{\mathrm{a}} \pm 33$ & $8.8^{b} \pm 8.8$ & $0^{\mathrm{b}} \pm 0$ \\
\hline Max. soil temp. $15 \mathrm{~cm}$ & 35.3 & 36.1 & 36.8 \\
\hline Max. soil temp. $5 \mathrm{~cm}$ & 45.2 & 42.6 & 43.7 \\
\hline Min. soil temp. $15 \mathrm{~cm}$ & 0.5 & 2.0 & 3.4 \\
\hline Min. soil temp. $5 \mathrm{~cm}$ & -3.5 & -1.4 & 0.6 \\
\hline
\end{tabular}

Mean values \pm SD are shown. Different letters indicate significant differences $(p<0.05)$.

Soil temperatures in the control plots at $15 \mathrm{~cm}$ and $5 \mathrm{~cm}$ depth strongly correlated $(r=0.99)$. Soil temperatures at $15 \mathrm{~cm}$ and $5 \mathrm{~cm}$ correlated more strongly with air temperatures $(r=0.92$ and $0.95)$ than with global radiation $(r=0.63$ and 0.67$)$. Soil moisture of the control plots was better correlated with relative humidity $\left(r_{s}=0.66\right)$, air temperature $\left(r_{s}=-0.61\right)$ and global radiation $\left(r_{s}=-0.78\right)$ than with precipitation $\left(r_{s}=0.35\right.$, all correlations significant at $p<0.05$ ).

\subsection{Heating effects on crop performance}

Time of seedling emergence (BBCH 10) in September did not differ significantly between the warming treatments. Progress of crop growth during October was slightly but not significantly faster in $+4{ }^{\circ} \mathrm{C}$ plots than in control plots (Fig. 8a). Plant growth during winter and spring did not differ between the warming treatments. The onset of flowering (BBCH 60) and the time of full flowering (BBCH 65 ), however, were significantly accelerated: both crop stages and took place 7 days earlier in $+2{ }^{\circ} \mathrm{C}$ plots and 14 days earlier in $+4{ }^{\circ} \mathrm{C}$ plots compared to control plots. Both Falcon and SEM reached full flowering (BBCH 65) significantly earlier in the $+4{ }^{\circ} \mathrm{C}$ plots than in the control plots.

Growth stages correlated weakly but significantly with temperature sums at three different time points. However, correlations with the temperature sum at $5 \mathrm{~cm}$ soil depth were slightly stronger than with the temperature sum at $15 \mathrm{~cm}$ for the three recording time points on 5 September $2010\left(r_{s}=0.39\right.$ vs. $\left.r_{s}=0.32\right), 13$ April $2011\left(r_{s}=0.64\right.$ vs. $\left.r_{s}=0.63\right)$ and 15 June $2011\left(r_{s}=0.53\right.$ vs. $\left.r_{s}=0.43, p<0.05\right)$. The degree of plant coverage (\%) was

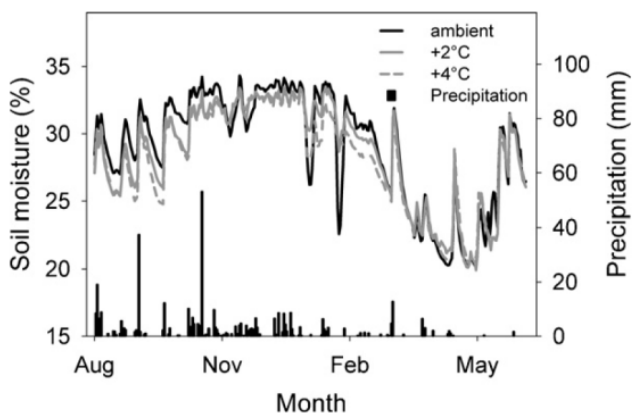

Fig. 7. Soil moisture in the three heating treatments and precipitation based on daily mean values. significantly increased in $+4{ }^{\circ} \mathrm{C}$ plots compared to the control plots on 29 September, 13 October and 20 October (Fig. 8b).

Plant length was influenced by both heating and cultivar. Until the end of April, plants in $+4{ }^{\circ} \mathrm{C}$ plots where significantly taller than those in control plots (Fig. 8c). During flowering and before harvest, however, plants in control plots where significantly taller than those in $+4^{\circ} \mathrm{C}$ plots. From May, there were significant cultivar effects, with Falcon growing higher than SEM. The stem base diameter did not differ significantly between the cultivars and warming treatments except for one sampling date (16 June). Here, the mean stem base diameter of Falcon was significantly higher than of SEM in control plots and $+2{ }^{\circ} \mathrm{C}$ plots (Fig. 8d). Within each variety, there was no clear heating effect on stem base diameter. Overall, plant growth was not negatively affected by the presence of heating cables. Tap roots grew either through the cable spaces into the deeper soil or around the cables.

\section{Discussion}

\subsection{Experimental setup and system performance}

This paper reports results from a year-round experiment with an outdoor soil temperature manipulation facility studying soil warming effects on winter oilseed rape, a crop with a vegetation period of 11 months. The experimental set-up allowed for common agricultural practices like minimum soil tillage, fertilizing, spraying and weeding. The heating cables used in this experiment were not affected by any of these activities and proved robust toward biotic stress and destructive sampling of whole plants. The experimenta setup was applied to an oilseed rape crop with characteristic tap roots, but could also be applied to study other important arable crops like wheat or maize.

The temperature control system worked reliably and generally independently from the seasonal cycle of air temperature. The targeted temperature offset between control and heated plots was maintained constant throughout the year, at least at $15 \mathrm{~cm}$ soil depth. Occasionally this offset limit was exceeded, mainly in winter and could be associated with low air temperature and limited soil moisture, hampering sufficient heat conductivity in the soil. In wet soil conditions, heat conductivity in the soil improved and ensured the desired target temperature was reached. At $5 \mathrm{~cm}$ soil depth, the more unstable temperature offset between control and heated plots was most likely due to the larger influence of fluctuating ambient air temperatures, but this could also be a result of the greater fluctuations in soil moisture in the upper soil layer. The temperature differences at $5 \mathrm{~cm}$ and $15 \mathrm{~cm}$ depth showed that the active soil 

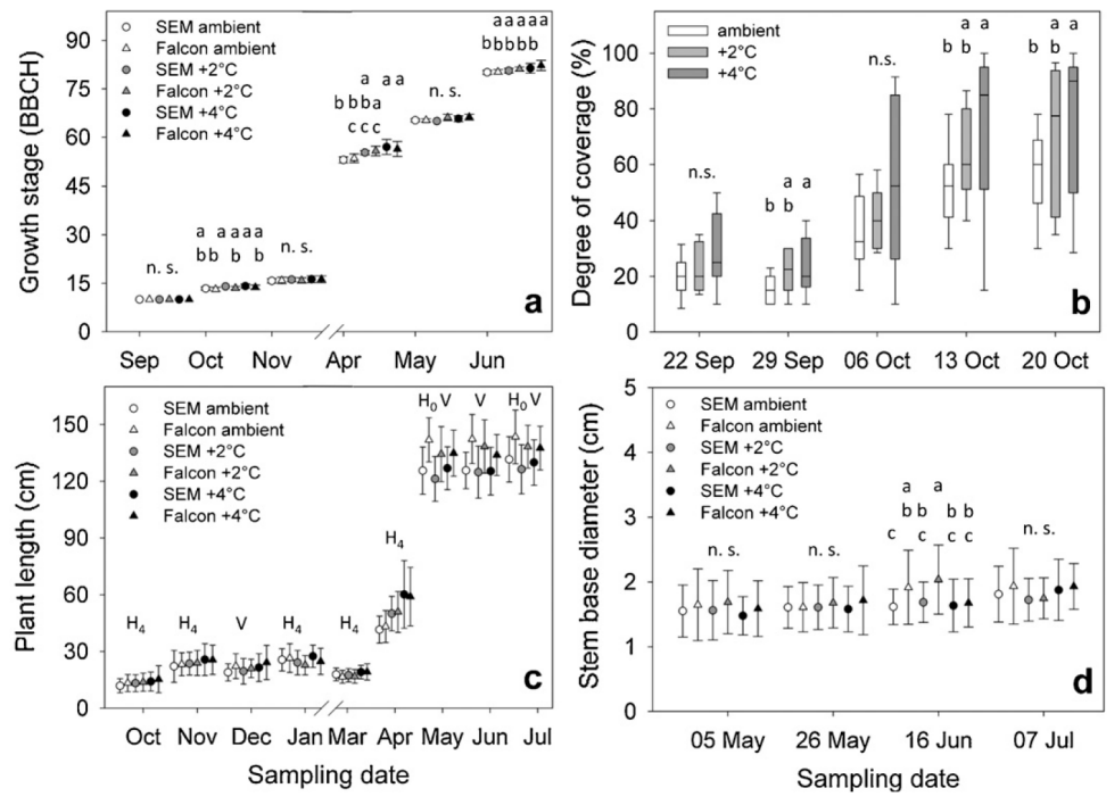

Fig. 8. Growth stages (a), degree of plant coverage (b), plant length (c) and stem base diameter (d) of two oilseed rape cultivars in the three warming treatments at different time points. Means $\pm \mathrm{SD}$ are shown. Different letters indicate significant differences. $p<0.05$. ns $=$ not significant; $n=5$ plants per treatment in (c) and (d). $\mathrm{H}=\operatorname{significant}$ heating effect, $\mathrm{H}_{4}=$ plus $4^{\circ} \mathrm{C}$ plots $>$ plus $2^{\circ} \mathrm{C}$ plots and/or control plots, $\mathrm{H}_{0}=$ control plots $>$ plus $2^{\circ} \mathrm{C}$ plots and $/$ or $+4{ }^{\circ} \mathrm{C}$ plots and $\mathrm{V}=$ significant variety effect (Falcon $>\mathrm{SEM}$ ) in (c).

warming technique used affected at least the upper $15 \mathrm{~cm}$ of soil volume. In our experiment, the required temperature gradient was reached within half a day, which is faster than in passive warming treatments (Mikkelsen et al., 2008). Snow cover melting patterns in winter and observations using an infrared camera in summer showed that there were no spill-over effects at the edges of plots influencing neighboring plots, hence the $50 \mathrm{~cm}$ spacing between plots proved to be sufficient.

Previous soil warming studies used a variety of cable burial depths $(1-10 \mathrm{~cm})$, cable spacings $(2-20 \mathrm{~cm})$, power intensities and temperature offsets ranging from 0.6 to $10^{\circ} \mathrm{C}$ (Butler et al., 2012; Hantschel et al., 1995; Patil et al., 2010; Schindlbacher et al., 2008 Verburg et al., 1999; Xiao et al., 2010). By choosing a cable burial depth of $10 \mathrm{~cm}$, a more even heat distribution was ensured than when cables were buried closer to the soil surface, also enabling soil tillage. Additionally, by placing control thermistors $5 \mathrm{~cm}$ below the heating cables, we prevented overheating on the one hand and insufficient heating below the target temperature at low soil moisture on the other hand, as previously stated by Peterjohn et al. (1993). Overheating was also prevented by choosing cables with only $100 \mathrm{~W} \mathrm{~m}^{-2}$ power density in the field experiment compared to 300 or $600 \mathrm{~W} \mathrm{~m}^{-2}$ during the pilot study. In contrast to Peterjohn et al. (1993), however, we achieved the lowest intercable temperature variability at $5 \mathrm{~cm}$ cable spacing in the pilot study. Hence, we used $5 \mathrm{~cm}$ cable spacing for the field experiment. In our study, a constant temperature offset was applied throughout the experimental year. Other studies used different offsets in summer and winter (Verburg et al., 1999), to simulate assumed warmer winters in the future. On the other hand, temperatures are also expected to increase more during nights than during days, and may be more variable in the future. Hence, both fixed and variable temperature offsets can adequately represent climate warming scenarios.

\subsection{Heating effects on the soil microclimate}

The effects of soil heating on soil moisture in our experiment were weak. Soil moisture in the upper $15 \mathrm{~cm}$ soil was occasionally reduced in the heated plots, especially in the fall, but this effect was not significant, in contrast to Hanson et al. (2011) who used a newly developed deep heater system which heated an even thicker soil layer. Kamp et al. (1998) also recorded reduced soil moisture in plots heated $+3{ }^{\circ} \mathrm{C}$. In our experiment, this could be explained by enhanced evaporation or higher water uptake by faster growing plants. The poor correlation of soil moisture in control plots with precipitation, and the negative correlation with global radiation in our study underline the importance of evapotranspiration processes at the plot level. The silty clay ensured a sufficient water holding capacity of the soil and probably favored thermal conductivity. The drop in soil moisture in January and February in the control plots compared to the heated plots was probably related to frost events reducing water mobility in the soil compared to the heated plots where frost events did not or only rarely occur.

\subsection{Heating effects on crop performance}

Patil et al. (2010) established a cable-based warming experiment with winter wheat similar to our system, but with a temperature offset of $5^{\circ} \mathrm{C}$. They found significant effects of soil warming on crop growth at early growth stages, but faster plant development in the control plot in spring when air temperatures rose. We observed a similar effect in our experiment with oilseed rape where plant length during vegetative growth stages was significantly higher in the $+4{ }^{\circ} \mathrm{C}$ plots compared to the control, but from flowering until harvest plants in control plots were significantly larger than in $+4{ }^{\circ} \mathrm{C}$ plots. Estrella et al. (2007) stated that rising air temperatures in the Northern Hemisphere resulted in an 
advance of leafing and flowering of crops by 4 days $/{ }^{\circ} \mathrm{C}$ in Germany which agrees with our experimental results using soil warming. Phenological advances due to soil warming may not only have implications for pollination or cause shifts in the diary of farmers by altering sowing and harvesting dates, but may also influence plant pathogens whose epidemiology is closely related with particular plant growth stages, e.g. Sclerotinia sclerotiorum (Siebold and Tiedemann, 2012). Previous studies also found direct effects of rising soil temperature on crop development, plant biomass, root growth and nutrient uptake (Gavito et al., 2001; Stone et al., 1999; Whitmore and Whalley, 2009). Additionally, changes in below ground physical, chemical and biological properties like wate relations, decomposition of organic matter and colonization with soil microbial communities (Brown et al., 2012; Jones et al., 2009; Pendall et al., 2008; Pritchard, 2011) may influence crop performance under global air and soil warming.

\subsection{Comparison with other experimental warming methods}

Cables have often been criticized for causing soil disturbance during installation, the creation of non-natural vertical temperature profiles in the soil and unwanted soil drying. Our experiment, however, did not support these criticisms. Cables were buried about 1 month before sowing of the crop, giving the upper soil layer time to settle. The soil temperature gradient between $15 \mathrm{~cm}$ and $5 \mathrm{~cm}$ depth was higher in the heated plots $\left(0.6\right.$ and $\left.0.8^{\circ} \mathrm{C}\right)$ than in the control plots $\left(0.3^{\circ} \mathrm{C}\right)$, but still in a comparable range. Although an elevated temperature below $15 \mathrm{~cm}$ in our experiment cannot be excluded, as described by Peterjohn et al. (1993), it is expected not to exceed the offset temperature limit. Fluid-filled pipes or heating cables located on the surface may be appropriate to hold a required temperature offset. However, overheating may occur with a denser plant cover (Hillier et al., 1994), and soil tillage may be compromised.

Above-ground infrared heaters (Bijoor et al., 2008; Harte et al., 1995; Nijs et al., 1996) are often considered to simulate the most natural warming effects on soil or crops. On the other hand unrealistic heating gradients and adverse conditions around aboveground plant parts may occur. Open air heating systems, in general, face the problem of being exposed to turbulent atmospheric conditions and lateral air flow in and out of the plots, often limiting the accurate differentiation between control and treated plots (Beie et al., 2004; Harte et al., 1995; Kimball, 2005). Open top chambers with a controlled microclimate (Hollister et al., 2006; Norby et al., 1997; Sullivan and Welker, 2005) can maintain a stable temperature offset and simulate natural soil warming from above. On the other hand, the temperature offset may be difficult to control on sunny or windy days, and this equipment is costly.

Passive warming methods like retractable curtains (Beier et al., 2004), plastic covered frames (Taulavuori et al., 2011), greenhouses or tents (Deslippe et al., 2011; Hobbie and Chapin, 1998) may simulate natural soil warming, while being cost and energy efficient. The main drawback, however, is that the temperature offse between control and heated is often not easily controlled and not stable. Frames and curtains are particularly unsuitable for simulating warming for $24 \mathrm{~h}$ a day since they alter irradiation conditions, and a rapidly growing plant cover may compromise their practicability.

Experiments considering several factors, such as temperature, precipitation, $\mathrm{CO}_{2}$ concentration and air pollutants have been demanded in previous studies. Since elevated soil temperature has received little attention in field experiments with agricultural crops until now, our study focused on soil warming under field conditions in order to supplement existing reports focusing on other factors arising from climate change.

\subsection{Conclusion}

The present study describes a robust, reliable, accurate and relatively cost-effective method to study climatic warming effects on the performance of an important arable crop, oilseed rape, under field conditions. The method allows for maintaining agronomic practices including minimum soil tillage and sampling of whole plants without affecting the experimental equipment or performance. This study plays the key part in a multidisciplinary approach, studying the effects of experimental warming on plant phenology, fungal pathogen and insect development, and decomposition of organic matter in the soil. The method of active soil heating established here is appropriate for long-term and wholeseason experiments using a variety of crops and also different crop rotations. A similar system could also be applied at other sites for large-scale manipulations. In the future, combining our approach with above-ground warming methods within a multi-effects experimental approach should be possible.

\section{Acknowledgements}

This work was financially supported by the Ministry for Science and Culture of Lower Saxony, Germany, within the research network "KLIFF" - climate impact in Lower Saxony". We thank Hans-Peter Suck (ADS Networks, Bad Homburg, Germany) for his support during development, installation and initiation of the temperature control and data logging system, and Volker Steckel (Lambrecht $\mathrm{GmbH}$ ) and Silke Schweighoefer (UP GmbH) for valuable discussions before sensor selection and installation. Furthermore, we are grateful to Frank Gremmes and Marc Fiebrich for technical support during the pilot study and maintenance during the field experiment as well as to Hubertus Reintke for agronomic support. Thanks also go to Dr Derek J. Barbara for proofreading the manuscript.

\section{References}

Aronson, E.L., McNulty, S.G., 2009. Appropriate experimental ecosystem warming methods by ecosystem, objective, and practicality. Agric. For. Meteorol. 149(11). 1791-1799.

Beier, C., Emmett, B., Gundersen, P., Tietema, A., Penuelas, J., Estiarte, M., Gordon, C. Gorissen, A., Llorens, L., Roda, F., Williams, D., 2004. Novel approaches to study climate change effects on terrestrial ecosystems in the field: drought and passive nighttime warming. Ecosystems 7 (6), 583-597.

Bijoor, N.S., Czimczik, C.I., Pataki, D.E., Billings, S.A., 2008. Effects of temperature and fertilization on nitrogen cycling and community composition of an urban lawn. Global Change Biol. 14, 2119-2131.

Braun-Blanquet, J 1964. Pflanzensoziologie: Grundzüge der Vegetationskunde, 3rd ed. Springer-Verlag, Vienna, 865 pp.

Brown, J.R., Blankinship, J.C., Niboyet, A., van Groenigen, K.J., Dijkstra, P., Le Roux, X Leadley, P.W., Hungate, B.A., 2012. Effects of multiple global change treatments on soil $\mathrm{N}_{2} \mathrm{O}$ fluxes. Biogeochemistry $109,85-100$.

Butler, S.M., Melillo, J.M., Johnson, J.E., Mohan, J., Steudler, P.A., Lux, H., Burrows, E. Smith, R.M., Vario, C.L., Scott, L., Hill, T.D., Aponte, N., Bowles, F., 2012. Soil warming alters nitrogen cycling in a New England forest: implications for ecosystem function and

Chakraborty, S., Tiedemann, A.v., Teng, P.S., 2000. Climate change: potential impact on plant diseases. Environ. Pollut. 108 (3), 317-326.

Christensen, J.H., Christensen, O.B., 2007. A summary of PRUDENCE model projections of changes in European climate by the end of this century. Clim. Change
tister tions of chan.

Deslippe, J.R., Hartmann, M., Mohn, W.W., Simard, S.W., 2011. Long-term experimental manipulation of climate alters the ectomycorrhizal community of Betula
mentiperi-, nana in Arctic tundra. Global Change Biol. 17 (4), 1625-1636.

Estrella, N., Sparks, T.H., Menzel, A., 2007. Trends and temperature response in the phenology of crops in Germany. Global Change Biol. 13 (8), in the phen

Gavito, M.E., Curtis, P.S., Mikkelsen, T.N., Jakobsen, I., 2001. Interactive effects of soil temperature, atmospheric carbon dioxide and soil $\mathrm{N}$ on root development, biomass and nutrient uptake of winter wheat during vegetative growth. J. Exp. Bot. 52 (362), 1913-1923.

Haberlandt, U., Belli, A., Hölscher, J., 2010. Trends in beobachteten Zeitreihen von Temperatur und Niederschlag in Niedersachsen. Hydrol. Wasserbewirtsch. 54 (1), 28-36. 
Hanson, P.J., Childs, K.W., Wullschleger, S.D., Riggs, J.S., Thomas, W.K., Todd, D.E. Warren, J.M., 2011. A method for experimental heating of intact soil profiles for application to climate change experiments. Global Change Bil profiles $1083-1096$.

Hantschel, R.E., Kamp, T., Beese, F., 1995. Increasing the soil temperature to study global warming effects on the soil nitrogen cycle in agroecosystems. J. Biogeogr. $22(2 / 3), 375-380$

Harte, J., Torn, M.S., Chang, F.-R., Feifarek, B., Kinzig, A.P., Shaw, R., Shen, K., 1995 Global warming and soil microclimate: results from a meadow-warming expeiment. Ecol. Appl. 5 (1) 132-150.

Hillier, S.H., Sutton, F., Grime, J.P., 1994. A new technique for the experimental manipulation of temperature in plant communities. Funct. Ecol. 8 (6), 755-762.

Hobbie, S.E., Chapin, F.S., 1998. The response of tundra plant biomass, aboveground production, nitrogen, and $\mathrm{CO}_{2}$ flux to experimental warming. Ecology 79 (5) 1526-1544.

Hollister, R.D., Webber, P.J., Nelson, F.E., Tweedie, C.E., 2006. Soil thaw and temperature response to air warming varies by plant community: results from an open-top chamber experiment in Northern Alaska. Arct. Antarct. Alp. Res. 38 (2) 206-215.

Jacob, D., Podzun, R., 1997. Sensitivity studies with the regional climate model REMO. Meteorol. Atmos. Phys. 63 (1), 119-129.

Jones, A., Stolbovoy, V., Rusco, E., Gentile, A.R., Gardi, C., Marechal, B., Montanarella, 2009. Climate change in Europe. 2. Impact on soil. A review. Agron. Sust. Dev. $29(3), 423-432$

Kamp, T., Steindl, H., Hantschel, R.E., Beese, F., Munch, J.C., 1998. Nitrous oxide emissions from a fallow and wheat field as affected by increased soil temperatures. Biol. Fertil. Soils 27 (3), 307-314.

Karl, T.R., Trenberth, K.E., 2003. Modern global climate change. Science 302 (5651), $1719-1723$.

Kimball, B.A., 2005. Theory and performance of an infrared heater for ecosystem warming. Global Change Biol. 11 (11), 2041-2056.

Lancashire, P.D., Bleiholder, H., Boom, T.V.D., Langelüddeke, P., Stauss, R., Weber, E Witzenberger A. 1991. A uniform decimal code for growth stages of crops and weeds. Ann. Appl. Biol. 119 (3) 561-601.

Mikkelsen, T.N., Beier, C., Jonasson, S., Holmstrup, M., Schmidt, I.K., Ambus, P. Pilegaard, K., Michelsen, A. Albert, K., Andresen, LC Arndal, M.F, Bruun, N. Christensen, S. Danb, KS S Gundersen, P. Rgensen, P . Linden, LG. Kongstad, J Maraldo, K., Priem, A, Riis-Nielsen, T, Ro-Poulsen, H., Stevnbak, K., Selsted, M. B. Rensen, P., Larsen, KS Carter, M. S, Ibrom, A., Martinussen, T. Miglietta, F, Sverdrup, H., 2008. Experimental design of multifactor climate change experiments with elevated $\mathrm{CO}_{2}$, warming and drought: the CLIMAITE project. Funct. Ecol. 22 185-195.

Nijs, I., Kockelbergh, F., Teughels, H., Blum, H., Hendrey, G., Impens, I., 1996. Free Air Temperature Increase (FATI): a new tool to study global warming effects on plants in the field. Plant Cell Environ. 19 (4), 495-502.
Norby, R., Edwards, N., Riggs, J., Abner, C., Wullschlegel, S., Gunderson, C., 1997. Temperature-controlled open-top chambers for global change research. Global Change Biol. 3 (3), 259-267.

Patil, R.H., Laegdsmand, M., Olesen, J.E., Porter, J.R., 2010. Growth and yield response of winter wheat to soil warming and rainfall patterns. J. Agric. Sci. 148, 553-566. Peltonen-Sainio, P., Hakala, K., Jauhiainen, L., Ruosteenoja, K., 2009. Comparing regional risks in producing turnip rape and oilseed rape-impacts of climate change and breeding. Acta Agric. Scand. B 59 (2), 129-138.

Pendall, E., Rustad, L., Schimel, J., 2008. Towards a predictive understanding of belowground process responses to climate change: have we moved any closer? Funct. Ecol. 22 (6), 937-940.

Peterjohn, W.T., Melillo, J.M., Bowles, F.P., Steudler, P.A., 1993. Soil warming and trace gas fl.

Pritchard, S. . 2011. Soil organisms and global climate change. Plant Pathol. 60 (1) $82-99$.

Schindlbacher, A., Zechmeister-Boltenstern, S., Kitzler, B., Jandl, R., 2008. Experimental forest soil warming: response of autotrophic and heterotrophic soil Siebold, M., Tiedemann, A.v., 2012. Potential effects of global warming on oilseed rape pathogens in Northern Germany. Fungal Ecol. 5 (1), 62-72.

Stone, P.J., Sorensen, I.B., Jamieson, P.D., 1999. Effect of soil temperature on phenology, canopy development, biomass and yield of maize in a cool-temperate climate. Field Crops Res. 63 (2), 169-178.

Sullivan, P.F., Welker, J.M., 2005. Warming chambers stimulate early season growth of an arctic sedge: results of a minirhizotron field study. Oecologia 142 (4), 616-626.

Taulavuori, K., Bauer, E., Taulavuori, E., 2011. Overwintering stress of Vaccinium vitisidaea in the absence of snow cover. Environ. Exp. Bot. 72, 397-403.

Tuck, G., Glendining, M.J., Smith, P., House, J.I., Wattenbach, M., 2006. The potential distribution of bioenergy crops in Europe under present and future climate. Biomass Bioenergy 30 (3), 183-197.

Verburg, P.S.J., Van Loon, W.K.P., Lükewille, A., 1999. The CLIMEX soil-heating experiment: soil response after 2 years of treatment. Biol. Fertil. Soils 28 (3), 271-276.

Weigel, H.J., 2005. Healthy plants in the future: how does climate change affect crop production? Gesunde Pflanzen 57 (1), 6-17 (German with English Abstract).

Werner, P., Gerstengarbe, F.W., 2007. Welche Klimaänderungen sind in Deutschland zu erwarten? In: Endlicher, W., Gerstengarbe, F.W. (Eds.), Der Klimawandel-Einblicke, Rückblicke und Ausblicke. Deutsche Gesellschaft fü Geographie, Potsdam, pp. 56-59.

Whitmore, A.P., Whalley, W.R., 2009. Physical effects of soil drying on roots and crop growth. J. Exp. Bot. 60 (10), 2845-2857. Xiao, G., Zhang, Q., Li, Y., Wang, R., Yao, Y., Zhao, H., Bai, H., 2010. Impact of tempera-
ture increase on the yield of winter wheat at low and high altitudes in semiarid northwestern China. Agric. Water Manage. 97 (9), 1360-1364. 


\title{
Chapter 4:
}

Global Change Biology (2013), doi: 10.1111/gcb.12180

\section{Effects of experimental warming on fungal disease progress in oilseed rape}

\author{
MAGDALENA SIEBOLD and ANDREAS VON TIEDEMANN \\ Department of Crop Sciences, Division of Plant Pathology and Crop Protection, Georg-August-University of Göttingen, \\ Grisebachstr 6, D-37077 Göttingen, Germany
}

\begin{abstract}
Global warming will influence the growth and development of both crops and pathogens. The aims of this study were to investigate potential effects of future warming on oilseed rape growth and the epidemiology of the three economically important pathogens Verticillium longisporum, Sclerotinia sclerotiorum, and Leptosphaeria maculans (anamorph: Phoma lingam). We utilized climate chambers and a soil warming facility, where treatments represented regional warming scenarios for Lower Saxony, Germany, by 2050 and 2100, and compared results of both approaches on a thermal time scale by calculating degree-days (dd) from day of sowing, December 1st and March 1st until sampling, the latter correlating best with disease progress. Regression analysis showed that plant growth and growth stages in spring responded almost linearly to increasing thermal time until 1000-1500 dd. Colonization of plant tissue by $V$. longisporum showed an exponential increase when exceeding 1300-1500 dd and reaching plant growth stage $\mathrm{BBCH} 74 / 75$ (pod development). V. longisporum colonization of plants may be advanced, potentially leading to higher inoculum densities after harvest and increased economic importance of this pathogen under future warming. Sclerotia germination of S. sclerotiorum reached its maximum at 600-900 dd. Advance of these critical degree-days may lead to earlier apothecia production, potentially advancing the infection window, whereas the future importance of $S$. sclerotiorum may remain constant. Severity of phoma crown canker increased linearly with increasing thermal time, but showed also large variation in response to the warming scenarios, suggesting that factors such as canopy microclimate in fall or leaf shedding over winter may play a bigger role for L. maculans infection and disease severity than higher soil temperatures. Thermal time was a suitable tool to combine and integrate data on biological responses to soil and air temperature increases from climate chamber and field experiments.
\end{abstract}

Keywords: climate change, degree-days, Leptosphaeria maculans/Phoma lingam, Sclerotinia sclerotiorum, soil warming, Verticillium longisporum

Received 21 November 2012; revised version received 12 February 2013 and accepted 14 February 2013

\section{Introduction}

Current climate modeling suggests a global warming which may lead to rising temperatures in agricultural production zones in the future. In Lower Saxony, Northern Germany, the mean temperature has increased by $1.3^{\circ} \mathrm{C}$ in the last 60 years (Haberlandt et al., 2010), and a further increase of up to $2{ }^{\circ} \mathrm{C}$ by 2050 and up to $4{ }^{\circ} \mathrm{C}$ by 2100 compared to the baseline period $1971-2000$ is projected (Regierungskommision Klimaschutz, 2012). This will also result in elevated soil temperatures (Hu \& Feng, 2003; Zhang et al., 2005), whereas other climatic factors, such as rainfall or relative humidity associated with cloud development, are projected with higher uncertainty (Karl \& Trenberth, 2003). Consequences for crop production may be shifts of agro-climatic zones and a changing phenology of crops in existing production zones (von Tiedemann, 1996; Weigel, 2005; Tuck et al.,

Correspondence: Magdalena Siebold, tel. + 4955139 14090, fax + 4955139 3706, e-mail: msiebol@gwdg.de
2006; Peltonen-Sainio et al., 2011), accompanied by changes in the occurrence of fungal pathogens (Colhoun, 1973; Eastburn et al., 2011; Juroszek \& von Tiedemann, 2012).

Experimental approaches in agricultural climate change research include manipulation experiments under controlled conditions and field experiments utilizing passive nighttime warming (Stone et al., 1999), open top chambers (Cheng et al., 2011), rainout shelters (Patil et al., 2010), infrared heaters (Kimball \& Conley, 2009) or above- and belowground heating cables (Xiao et al., 2010). However, most experiments focused on plant or soil responses to experimental warming or air composition, whereas effects on fungal pathogens have mostly been studied by theoretical approaches comparing biological requirements of disease cycles with future climate projections (West et al., 2012) or a combination of climate, crop, and disease models to project future crop yield losses (Butterworth et al., 2010; Evans et al., 2010). Field manipulation studies, particularly focusing on warming effects on plant diseases, are lacking. 


\section{M. SIEBOLD \& A. VON TIEDEMANN}

Oilseed rape (Brassica napus L.) is the most important crop for edible oil, fodder, and biofuel production in Europe (Van der Velde et al., 2009). The largest threat to yield is imposed by Leptosphaeria maculans (anamorph: Phoma lingam), a plant debris-borne pathogen causing leaf lesions after spore infection in autumn and severe stem and crown canker in the following spring after systemic growth or new infection (Fitt et al., 2006). Sclerotinia sclerotiorum can cause considerable yield losses of oilseed rape in years with favorable weather conditions for ascospore infection during mid to end of flowering (Koch et al., 2007). Spores are released from apothecia which germinate from soil-borne sclerotia in spring. Verticillium longisporum survives via microsclerotia in the soil and gained increased importance in areas with intense oilseed rape crop rotations in the past. The pathogen infects oilseed rape roots and grows through the xylem into the shoots after a long latency period causing premature ripening before harvest (Dunker et al., 2008).

There are numerous studies on the effect of temperature, the single most important environmental factor affecting plant pathogen development (Analytis, 1977) on the epidemiology of oilseed rape pathogens under controlled conditions and in the field. However, results have not been comparable between different experimental approaches due to variable temperature regimes and a focus on physical time scales (e.g., hours or days after inoculation). Thermal time or physiological time, i.e., the accumulation of daily temperatures above a certain threshold or base temperature within a defined time period, has been widely used in studies on plant growth, phenology, and species distribution (Schwartz et al., 2006; Parmesan, 2007; Peltonen-Sainio et al., 2009, 2011; Pau et al., 2011) in the context of global warming, but there are only few applications in plant disease epidemiology (Lovell et al., 2004). One major benefit of the thermal time concept is comparability of studies with different sampling time points and temperature regimes. Among oilseed rape pathogens, thermal time was utilized to study apothecia production of S. sclerotiorum (Clarkson et al., 2004), onset of leaf spot and stem canker caused by L. maculans (Toscano-Underwood et al., 2003; Evans et al., 2006) and leaf lesion development of Pyrenopeziza brassicae (Figueroa et al., 1995), whereas similar studies on $V$. longisporum do not exist so far.

On the basis of a meta-analytical approach (Siebold \& von Tiedemann, 2012a), we hypothesize that future warming may particularly favor the development of Sclerotinia and Verticillium. The objectives of this study were to investigate potential effects of mid-term and long-term future warming on the development of oilseed rape and its three major fungal pathogens
L. maculans, S. sclerotiorum, and V. longisporum by utilizing both climate chamber and field manipulation experiments simulating regional mid- and long-term warming scenarios for Lower Saxony, Germany. Results of both experimental approaches were compared using an integrative approach based on thermal time to supplement studies on crop or insect pest development which are frequently based on degree-days, potentially enabling the assessment of plant-insectpathogen interactions under future warming.

\section{Materials and methods}

\section{Climate chamber experiments}

Growth conditions. Experiments under controlled conditions were carried out in five RUMED ${ }^{\circledast}$ light thermostats type 1401S (Rubarth Apparate GmbH, Laatzen, Germany) which offered a space of $4 \mathrm{~m}^{3}$, enabling the growth of mature plants on height adjustable grids. Each chamber featured 10 wide beam $150 \mathrm{~W}$ ceramic metal halide lamps (Iwasaki Electric Co. Ltd., Tokyo, Japan) with a maximum luminous intensity of $5500 \mathrm{~cd}$ each. Two types of these lamps were jointly used to produce a balanced light spectrum from blue to red with an emission maximum in photosynthetically active radiation to enable normal crop growth (Mortensen \& Strømme, 1987). Plants in the five chambers were exposed to an average light intensity of 98 (pot level) to 340 (flower or pod level) $\mu \mathrm{m} \mathrm{m}^{-2} \mathrm{~s}^{-1}$, with 140 $170 \mu \mathrm{m} \mathrm{m}^{-2} \mathrm{~s}^{-1}$ in the leaf position zone, creating conditions appropriate for oilseed rape cultivation (Potter et al., 1999). Day and night baseline temperatures were provided in reference chamber 1 and reflected the monthly average of daily maximum and minimum temperatures of Bad Harzburg, one of the coldest locations in Lower Saxony, during the period from 1970 to 2000 (Table 1). In the remaining four chambers, temperatures were elevated by $2{ }^{\circ} \mathrm{C}$ steps, establishing an overall temperature range from the coldest to the warmest chamber of $8{ }^{\circ} \mathrm{C}$, thus simulating both current regional temperature differences and future warming scenarios in Lower Saxony. Temperature profiles were adjusted to monthly averages simulating the period from March to July. Day lengths ranged from $12 \mathrm{~h}$ in March to $15 \mathrm{~h}$ in June, relative humidity from $76 \%$ to $92 \%$, depending on the temperature level and intensity of plant watering.

Climate chamber experiments with $V$. longisporum. Microsclerotia of $V$. longisporum (strain $\mathrm{Vl} 43$, Northern Germany, 1990), which is pathogenic on Brassica napus, were produced in vitro on a sand-oatmeal-water mixture as described previously (Dunker $e$ t al., 2008). Seedlings at growth stage BBCH 10 of spring oilseed rape cultivar Heros (Raps GbR, Grundhof, Germany), moderately susceptible to $V$. longisporum (Keunecke, 2009) were transferred to pots containing each $700 \mathrm{~g}$ of a potting soil-compost-sand mixture (ratio $3: 3: 1$ ) amended with $50 \mathrm{mg}$ of microsclerotia per $100 \mathrm{~g}$, which represents a moderate inoculum density (Stadler, 2010). Control pots received no microsclerotia. Twenty inoculated and noninocu- 
Table 1 Day and night temperatures and light regime in the five climate chambers. Temperatures in chamber 1 (reference chamber) reflect monthly average of daily maximum and minimum temperatures in Bad Harzburg, Lower Saxony, during the period 1970-2000. Temperature accuracy in the chambers was $\pm 0.5{ }^{\circ} \mathrm{C}$

\begin{tabular}{|c|c|c|c|c|c|c|c|c|c|c|c|}
\hline \multirow{2}{*}{$\begin{array}{l}\text { Simulated } \\
\text { month }\end{array}$} & \multirow{2}{*}{$\begin{array}{l}\text { Photoperiod } \\
\text { (hours) }\end{array}$} & \multicolumn{2}{|c|}{ Chamber 1} & \multicolumn{2}{|c|}{ Chamber 2} & \multicolumn{2}{|c|}{ Chamber 3} & \multicolumn{2}{|c|}{ Chamber 4} & \multicolumn{2}{|c|}{ Chamber 5} \\
\hline & & \multicolumn{10}{|c|}{ Day and night temperatures $\left({ }^{\circ} \mathrm{C}\right)$} \\
\hline March & 12 & 8 & $5^{*}$ & 10 & $5^{*}$ & 12 & 5 & 14 & 7 & 16 & 9 \\
\hline April & 13 & 12 & $5^{*}$ & 14 & 5 & 16 & 7 & 18 & 9 & 20 & 11 \\
\hline May & 14 & 18 & 8 & 20 & 10 & 22 & 12 & 24 & 14 & 26 & 16 \\
\hline June & 15 & 20 & 11 & 22 & 13 & 24 & 15 & 26 & 17 & 28 & 19 \\
\hline July & 14 & 22 & 13 & 24 & 15 & 26 & 17 & 28 & 19 & 30 & 21 \\
\hline
\end{tabular}

*Night temperature minimum $\left(=5{ }^{\circ} \mathrm{C}\right)$ due to technical restrictions of the climate chambers.

lated pots (pseudoreplicates) were placed in each of the five climate chambers at the beginning of the simulated March climate program in a randomized design. Plants were watered regularly and fertilized according to demand. From the beginning of flowering (after 8-9 weeks) four plants from each treatment were harvested from each chamber at five time points in 2-week intervals. Plant height and phenological stage (BBCH; Lancashire et al., 1991) were determined and disease symptoms were scored on leaves and stems according to Zeise \& Seidel (1990), from 1 (no symptoms) to 9 (strong microsclerotia production). Five $\mathrm{cm}$ of stem tissues at $10 \mathrm{~cm}$ above the hypocotyls was excised from the harvested plants, immediately frozen in liquid nitrogen, and stored at $-20^{\circ} \mathrm{C}$ for qPCR analysis. The samples from control plants of each chamber were merged to one pooled stem sample per chamber, whereas samples from inoculated plants were analyzed individually. The whole experiment was repeated twice.

Climate chamber experiments with S. sclerotiorum. Sclerotia of S. sclerotiorum (strain Ss 1.5 derived from B. napus, Biestow, Germany, 1997) were produced similar to microsclerotia of $V$. longisporum (Dunker et al., 2008). They were buried $10 \mathrm{~cm}$ deep in an oilseed rape field during winter (19 November 2009 to 14 April 2010) for conditioning and stored afterward at $10{ }^{\circ} \mathrm{C}$. Ten sclerotia were buried at $2 \mathrm{~cm}$ soil depth in small plastic trays filled with autoclaved top soil from the soil warming facility (see below). Six of these trays were placed in each of the five climate chambers next to the oilseed rape pots of the $V$. longisporum experiment. Trays were kept moist throughout the experiment and the number of produced apothecial primordia was counted weekly. The experiment was repeated twice.

\section{Soil warming field experiments}

Experimental design. Field experiments were carried out at the miniplot soil warming facility in Göttingen, Lower Saxony, Germany, during 2010/11 and 2011/12. The technical details and basic performance of the facility have been described previously (Siebold \& von Tiedemann, 2012b). Briefly, the facility consists of 12 plots $\left(5 \mathrm{~m}^{2}\right)$ equipped with heating cables, soil temperature and soil moisture sensors, and a weather station to obtain aboveground meteorological data at a 10-minute interval. Heating treatments included (T) ambient soil temperature, (T1) ambient $+1.6{ }^{\circ} \mathrm{C}$, and (T2) ambient $+3.2{ }^{\circ} \mathrm{C}$, the latter resembling warming scenarios for Lower Saxony by 2050 (mid-term) and 2100 (long-term), respectively. Each of the three treatments was repeated four times in a randomized block design. The programmed soil temperature offsets in the field experiments were kept stable during the course of the experiments. Deviation from the programmed target temperature in 2011/12 was slightly higher than in 2010/11, probably due to the increased number of frost hours (Table 2).

Fungal inoculum. Stubbles colonized with $V$. longisporum microsclerotia were harvested from an infested oilseed rape field near Göttingen in 2010. The material was shredded and $15 \mathrm{~g}$ per square meter was buried at $5 \mathrm{~cm}$ soil depth in each

Table 2 Key soil climate parameters from the field experiment in the two growing seasons 2010/11 and 2011/12. Mean values \pm SD. Different letters within rows indicate significant differences between warming treatments in each season $(P<0.05)$, $\mathrm{T}=$ ambient plots, $\mathrm{T} 1=+1.6{ }^{\circ} \mathrm{C}, \mathrm{T} 2=+3.2{ }^{\circ} \mathrm{C}$

\begin{tabular}{|c|c|c|c|c|c|c|}
\hline & \multicolumn{3}{|l|}{ 2010/11 } & \multicolumn{3}{|l|}{$2011 / 12$} \\
\hline & $\mathrm{T}$ & $\mathrm{T} 1$ & $\mathrm{~T} 2$ & $\mathrm{~T}$ & $\mathrm{~T} 1$ & $\mathrm{~T} 2$ \\
\hline Mean annual soil temp $5 \mathrm{~cm}\left({ }^{\circ} \mathrm{C}\right)$ & $9.3 \pm 0.3^{\mathrm{a}}$ & $10.7 \pm 0.2^{\mathrm{b}}$ & $12.1 \pm 0.1^{\mathrm{c}}$ & $9.9 \pm 0.2^{\mathrm{a}}$ & $11.2 \pm 0.1^{\mathrm{b}}$ & $12.5 \pm 0.1^{\mathrm{c}}$ \\
\hline Mean annual soil temp $15 \mathrm{~cm}\left({ }^{\circ} \mathrm{C}\right)$ & $9.6 \pm 0.3^{\mathrm{a}}$ & $11.3 \pm 0.3^{\mathrm{b}}$ & $12.9 \pm 0.3^{c}$ & $10.0 \pm 0.2^{\mathrm{a}}$ & $11.7 \pm 0.2^{\mathrm{b}}$ & $13.3 \pm 0.2^{\mathrm{c}}$ \\
\hline Mean annual soil moisture (\%) & $29.0 \pm 0.7^{\mathrm{a}}$ & $28.5 \pm 0.7^{\mathrm{a}}$ & $28.2 \pm 1.6^{\mathrm{a}}$ & $29.2 \pm 2.7^{\mathrm{a}}$ & $30.6 \pm 2.9^{\mathrm{a}}$ & $29.3 \pm 2.3^{\mathrm{a}}$ \\
\hline Frost hours $5 \mathrm{~cm}$ & $116.5 \pm 33^{\mathrm{a}}$ & $8.8 \pm 8.8^{\mathrm{b}}$ & $0^{\mathrm{b}}$ & $323.0 \pm 11.8^{\mathrm{a}}$ & $189.3 \pm 21.9^{\mathrm{b}}$ & $40.0 \pm 35.7^{c}$ \\
\hline Frost hours $15 \mathrm{~cm}$ & $0^{\mathrm{a}}$ & $0^{\mathrm{a}}$ & $0^{\mathrm{a}}$ & $276.0 \pm 3.4^{\mathrm{a}}$ & $0^{\mathrm{b}}$ & $0^{\mathrm{b}}$ \\
\hline
\end{tabular}


plot before sowing in 2010 and 2011. One hundred sclerotia of S. sclerotiorum were buried at $5 \mathrm{~cm}$ soil depth in each plot in August 2011. Twenty rapeseed stubbles colonized with pycnidia and pseudothecia of L. maculans harvested from rapeseed fields near Göttingen in 2010 and 2011 were placed in each plot after sowing in 2010 and 2011 to induce leaf infection in fall as well as crown canker development in spring. As this study addressed the effects of climate on disease development at inoculum levels found in commercial rapeseed fields, noninoculated controls were not included in the experiment.

Plant material and crop management. The winter oilseed rape cultivar Falcon (NPZ, Hohenlieth, Germany) and the breeding line SEM 05-500256 (SW Seed, Sweden; abbreviated SEM throughout the manuscript), susceptible and tolerant to $V$. longisporum, respectively, (Eynck et al., 2009) were sown by hand in a split plot design on 25 August 2010 and 22 August 2011 with a distance of $14 \mathrm{~cm}$ between rows and $7 \mathrm{~cm}$ within rows, achieving a seeding density of 70 seeds per square meter. Weeds were controlled by treatment with glyphosate prior to sowing and by hand during the course of the experiment. Fertilizers and growth regulators were applied in fall and spring according to good farming practice. Fungicides were not applied in order not to interfere with warming effects on fungal development.

Phenotypic measurements, plant sampling, and disease scoring. Phenological stage $(\mathrm{BBCH})$ and plant height were assessed during both growing seasons on a biweekly basis. Phoma leaf spots per plant were counted on 10 plants per treatment replicate and cultivar on 24 November 2010 and 21 November 2011. Germination of S. sclerotiorum sclerotia was assessed twice a week starting from April 2012.

Plants (10 plants per subplot in 2011 and 8 plants in 2012) were sampled on 12 December 2010 and 5 December 2011, and in regular intervals starting from mid April in 2011 (April 13th, May 5th, May 26th, June 16th, July 7th) and from March in 2012 (March 2nd, April 11th, May 8th, June 5th, July 4th). Phenological stage and plant height were determined for each single plant. Samples for qPCR analysis of $V$. longisporum colonization were taken from $5 \mathrm{~cm}$ stem sections $10 \mathrm{~cm}$ above the hypocotyl. Single plants were merged to pooled samples of $2 \times 5$ plants in 2011 and $2 \times 4$ plants in 2012 from each plot, frozen in liquid nitrogen and stored at $-20{ }^{\circ} \mathrm{C}$ until analysis. Phoma disease severity was assessed by calculating the volume of diseased tissue (VDT) of root collars based on extent and depth of lesions (Keunecke, 2009) on plants sampled in spring and summer.

Plots were harvested on 12 July 2011 and 2012. Disease incidence and severity of $V$. longisporum were assessed by visual scoring of microsclerotia density on roots, stem pith, and stem epidermis based on a scale from 1 to $4(1=$ no microsclerotia visible, 2 = low abundance of microsclerotia, 3 = high abundance of microsclerotia, $4=$ heavily infested tissue with epidermis peeling off).

Measurement of plant colonization with $V$. longisporum by $q P C R$. Fungal biomass of $V$. longisporum in plant tissue from both climate chamber and field plants was determined by
qPCR. Samples from storage at $-20^{\circ} \mathrm{C}$ were lyophilized for 72 h (Freeze Dryer Alpha 1-4; Martin Christ Freeze Dryers, Osterode am Harz, Germany) and milled with a ball mill (Retsch MM 200, Retsch GmbH, Haan, Germany). DNA was extracted from $20 \mathrm{mg}$ ( $100 \mathrm{mg}$ in the second field year) of plant material using a modified $\mathrm{CTAB}$ protocol (Brandfass \& Karlovsky, 2006) with the DNA pellet being resolved in $100 \mu \mathrm{l} \mathrm{TE}$ buffer. Standards from $1 \mathrm{ng}$ to $0.1 \mathrm{pg} V l$-DNA $\mu \mathrm{l}^{-1}$ were produced from pure $V$. longisporum DNA and concentration was determined by densitometry (Multi-Analyst software, Version 1.1; Bio-Rad Laboratories, Hercules, CA, USA). DNA samples were diluted to about 10-20 ng DNA $\mu \mathrm{l}^{-1}$ and subjected to qPCR analysis according to J. Knüfer (unpublished results), modified from Eynck et al. (2007).

\section{Data analysis}

Data were analyzed with the STATISTICA v. 9.1 software (StatSoft Inc., Tulsa, Ok, USA). Two-way ANOvA or One-way ANOVA on ranks and multicomparison by Tukey's HSD test were applied for field data to test for main effects of the factors 'warming' and 'variety' on plant height, colonization of plant tissue by $V$. longisporum and Phoma VDT for each sampling date. One-way ANOVA on ranks and Tukey HSD were used to assess the significance of differences in frost hours, annual mean soil temperature, and soil moisture in different soil depths due to the three temperature regimes in the field experiment, and in disease parameters recorded on climate chamber plants subjected to the five different temperature regimes. Spearman rank correlation coefficients were calculated to establish the relationship between climatic parameters, phenological stage $(\mathrm{BBCH})$ and the various disease parameters. The thermal time was quantified by accumulation of degree-days (dd), calculated from the daily average air (climate chambers) and soil (field experiments) temperatures $>0{ }^{\circ} \mathrm{C}$ starting from the day of sowing, December 1st or March 1st until sampling. This parameter enabled integration of results, i.e., the comparison of climate chamber and field results based on the same scale. Relationships between accumulated degree-days and disease development in climate chamber and field experiments were established by linear and nonlinear regression analyses. For all analyses, $P$ values $\leq 0.05$ were considered significant.

\section{Results}

\section{Effects of experimental warming on plant growth}

In general, biological parameters correlated better with dd from March 1st than dd from day of sowing or from December 1st, hence dd from March 1st were used for further analyses. Degree-days $>0{ }^{\circ} \mathrm{C}$ accumulated from March 1st significantly correlated with plant growth stage and plant height in the climate chamber and field experiments (Table 3). Plant height followed an almost linear increase between 500 and $1000 \mathrm{dd}$ from March 1st, followed by a moderate saturation (Fig. 1a). Until flowering, plants from warmer climate chambers grew 
Table 3 Relationship between degree-days $\left(>0{ }^{\circ} \mathrm{C}\right.$ from March 1st) until sampling $(x)$ and plant growth and disease parameters ( $y$ ) in both climate chamber and both field experiments

\begin{tabular}{llll}
\hline Plant and disease parameters & Reg. type & Regression function (compare Fig. 1) \\
\hline Plant height climate chambers & $\mathrm{p}$ & $y=-0.0007 x^{2}+2.586 x-909.7$ \\
Plant height SEM field experiments & $\mathrm{p}$ & $y=-0.00007 x^{2}+0.1985 x-19.498$ \\
Plant height Falcon field experiments & $\mathrm{p}$ & $y=-0.00008 x^{2}+0.2198 x-23.748$ \\
BBCH climate chambers & $\mathrm{p}$ & $y=0.00002 x^{2}+0.0901 x-5.561$ & 0.81 \\
BBCH SEM field experiments & $\mathrm{p}$ & $y=-0.000009 x^{2}+0.0424 x+38.422$ \\
BBCH Falcon field experiments & $\mathrm{p}$ & $y=-0.000006 x^{2}+0.038 x+40.452$ \\
$V l$-DNA stem climate chambers & $\mathrm{e}$ & $y=0.0048 \mathrm{e}^{1.9688 x}$ & 0.62 \\
$V l$-DNA stem SEM field experiments & $\mathrm{e}$ & $y=0.0000004 \mathrm{e}^{4.8629 x}$ \\
Vl-DNA stem Falcon field experiments & $\mathrm{e}$ & $y=0.00002 \mathrm{e}^{3.7319 x}$ & 0.95 \\
Ss primordia climate chambers & $\mathrm{p}$ & $y=-0.000003 x^{2}+0.0071 x-0.363$ \\
Ss apothecia field experiment 2011/12 & 1 & $y=0.0728 x-9.965$ & 0.57 \\
Lm VDT SEM field experiments & 1 & $y=0.00137 x-0.131$ \\
Lm VDT Falcon field experiments & $\mathrm{l}$ & $y=0.00248 x-0.225$ \\
\hline
\end{tabular}

Regression functions and coefficients are shown (all significant for $P<0.0001$, except *: $P=0.002$ ).

Vl, Verticillium longisporum; Ss, Sclerotinia sclerotiorum; Lm, L. maculans; l, linear; e, exponential; p, polynomial regression.

taller (not significant for all sampling time points) but after flowering differences in plant height decreased. Plant height was the only measured variable differing significantly between the two growth chamber runs $(P=0.003)$

In the field experiment 2010/11, plants before flowering were significantly higher in T2 plots compared with $\mathrm{T}$ plots, but until the sampling time point in July plants in $\mathrm{T}$ plots grew significantly bigger than in T1 plots. In 2011/12, plants from T1 and T2 plots were significantly higher than plants from $\mathrm{T}$ plots until flowering, whereas in later stages differences in height were not significant. On the average, plants in 2011/12 were $30 \%$ shorter than in 2010/11. Plant losses occurred after the particularly cold winter 2011/12 when daily average temperatures at the beginning of February suddenly dropped below $-12{ }^{\circ} \mathrm{C}$. Losses were higher for Falcon (36\%) than for SEM (23\%). SEM plant losses due to frost damage were similar in all warming treatments, whereas losses of Falcon were significantly increased in T2 plots (44\%) compared with T1 and T plots (32\%).

Flowering was reached after 500 and $1000 \mathrm{dd}$ from March 1st in the field and climate chambers, respectively (Fig. 1b). Plant phenology was generally advanced in warmer chambers, particularly flowering which started 1-2 weeks earlier in all warmer chambers compared with the reference chamber. In the field experiment, flowering started 1 week later in 2012 than in 2011. In 2011, flowering was advanced by 1 week in T1 plots and up to 2 weeks in T2 plots compared with ambient plots, whereas in 2012 advance of flowering in warmer plots was less clear. At the end of flowering, after $1000 \mathrm{dd}$ in the field and $1300 \mathrm{dd}$ in climate chambers, phenologic development slowed down and was similar among all chambers and plots. An increase of air temperature in climate chambers and soil temperature in the field by $2{ }^{\circ} \mathrm{C}$ resulted in $1000 \mathrm{dd}$ being reached on average 7.1 days earlier compared to ambient conditions.

\section{Effects of experimental warming on $V$. longisporum}

In the climate chamber experiments, $V l$-DNA content in stems increased with increasing disease severity as measured by disease scores $\left(r^{2}=0.53\right.$ in experiment 1 and $r^{2}=0.20$ in experiment $2, P<0.001$ ). The five temperature levels had no significant effect on plant colonization with $V l$, except for the fourth sampling time point $(1677 \pm 142 \mathrm{dd}$ at $\mathrm{BBCH} 74 / 75)$, where plants in chamber four $\left(+6{ }^{\circ} \mathrm{C}\right)$ were significantly stronger colonized with $\mathrm{Vl}$ than plants in all other chambers in both experiments (Fig. 2). Vl-DNA content in stems increased with crop age as measured by $\mathrm{BBCH}$ scale $\left(r^{2}=0.38, P<0.001\right)$, growing exponentially from 1300 dd (Figs 1c and 3a).

In field plants, $\mathrm{Vl}$-DNA was first detected on May 5th in 2011 and on May 8th in 2012. However, the average level of plant colonization with $\mathrm{Vl}$ in July was three to four times higher in 2011 than 2012. In 2011, Vl colonization of Falcon was significantly stronger than in SEM for the sampling time points from May 26th onwards. Significantly higher $\mathrm{Vl}$ colonization of oilseed rape stems was recorded in plants from T2 plots compared with $\mathrm{T}$ plots at sampling time points in May and on July 7th. In 2012, significant differences between cultivars were detected in May, June, and July, but heating had no significant effect on $\mathrm{Vl}$ colonization. In both years, however, $\mathrm{Vl}$-DNA content in SEM exponentially 

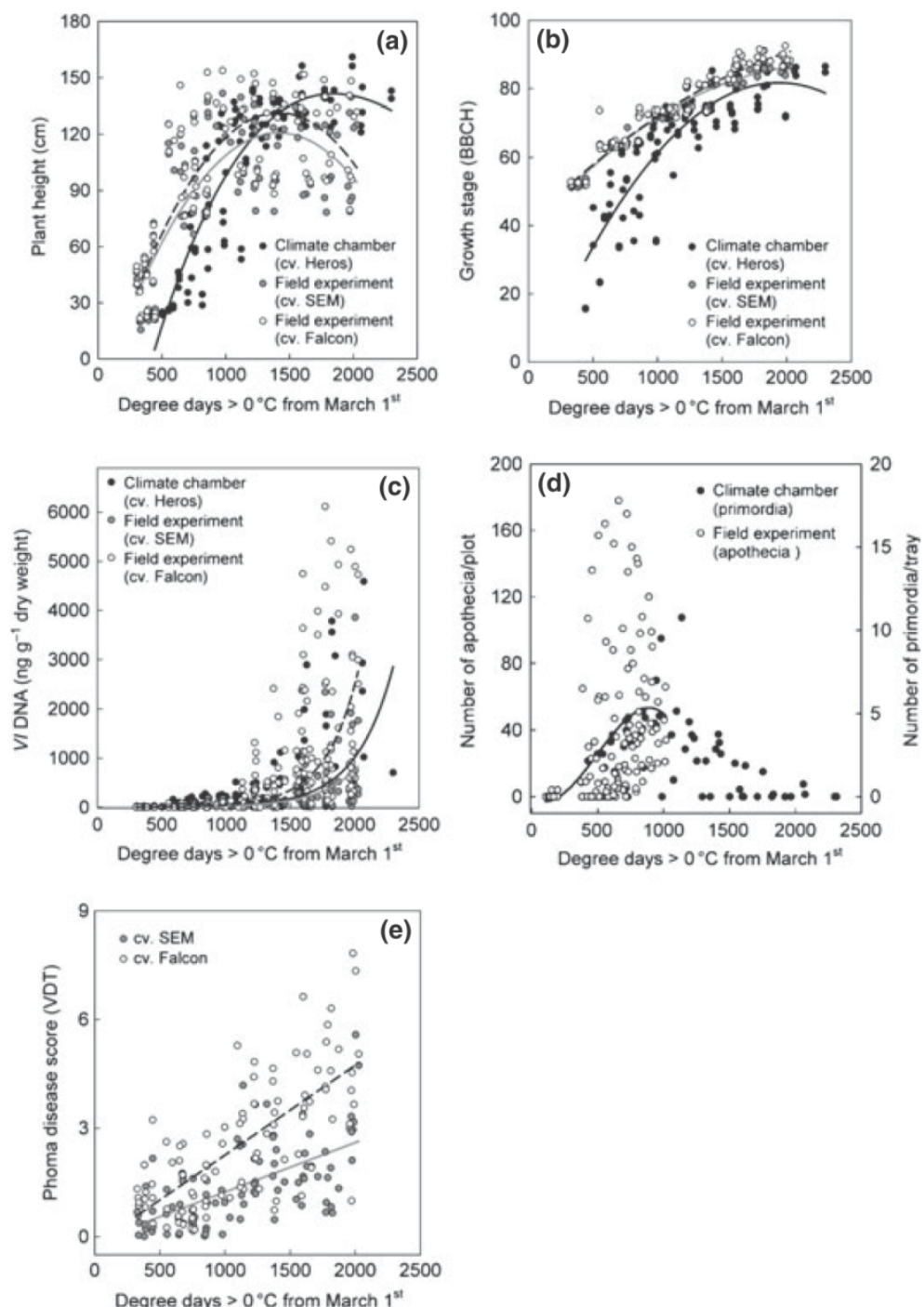

Fig. 1 Regression analysis on the relationship between degree-days $>0{ }^{\circ} \mathrm{C}$ from March 1st and the biological parameters plant height (a), plant growth stages (b), colonization of oilseed rape stems with Verticillium longisporum (c), production of apothecial primordia (climate chamber) and apothecia (field experiment 2011/12) of Sclerotinia sclerotiorum (d) and Phoma crown canker (e) at multiple sampling time points. Each data point represents the average of 4-5 pooled plants. For field data, each of the four replicates of the growing seasons 2010/11 and 2011/12 is shown separately. cv. = cultivar.

increased after $1500 \mathrm{dd}$ from March 1st when plants had reached BBCH 75 (Figs 1c and 3b). In Falcon, substantial increase of $\mathrm{Vl}$-DNA started already at $1300 \mathrm{dd}$ from March 1st (Fig. 3c). The increase of $V l$-DNA content with increasing crop age was clearer in the field for SEM $\left(r^{2}=0.66, P<0.001\right)$ and Falcon $\left(r^{2}=0.71\right.$ $P<0.001)$ than for the growth chamber plants. In both years, $V l$-DNA content increased with increasing disease severity based on stubble scoring $\left(r^{2}=0.21\right.$ and 0.23 , respectively, $P \leq 0.001$ ). In accordance with Vl-DNA readings, disease incidence was higher in 2011 (59\%) than in $2012(38 \%)$, and twice as high in Falcon (78\% and 52\%) compared to SEM (39\% and 23\%). In both experimental years, soil temperature had no significant effect on disease incidence. $V l$ colonization was stronger related to dd from March 1st than dd from sowing or from December 1st (Table 4). Thermal requirements for initiation of exponential growth of $\mathrm{Vl}$ 
were 1300 and 1500 dd from March 1st for Falcon and SEM, respectively. By experimental increase in air (climate chambers) and soil (field) temperature by $2{ }^{\circ} \mathrm{C}$ above ambient conditions, these critical thresholds were reached 8.1-8.3 days earlier in the growing season.

Effects of experimental warming on apothecia development of S. sclerotiorum

In the climate chamber experiments, sclerotia germination started after 7 weeks in all chambers, at a range from 384 to $714 \mathrm{dd}$. During the following 8 weeks, numbers of apothecial primordia quickly declined in the warmer chambers whereas maximum germination was delayed in the colder chambers (Table 5). The

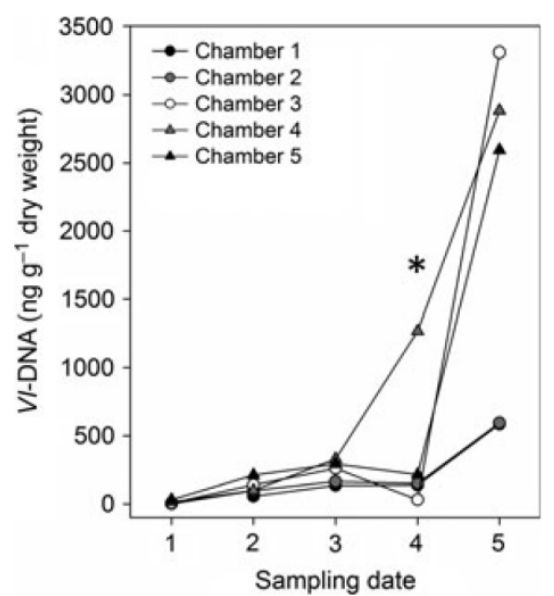

Fig. 2 Colonization of oilseed rape stems with Verticillium longisporum at five temperature levels (Table 1) and five sampling time points measured by qPCR. * indicates significantly higher $V l$-DNA content in chamber 4 compared with all other chambers. At all other sampling time points, there was no statistically significant difference between chambers. optimum rate of sclerotia germination and primordia production was recorded at a thermal time of $900 \mathrm{dd}$ (Fig. 1d), which was reached 7.1 days earlier under experimental warming by $2{ }^{\circ} \mathrm{C}$ above ambient.

In the field, first apothecia of S. sclerotiorum appeared on March 16th, 2012 in one of the T2 plots at $150 \mathrm{dd}$ from March 1st (Fig. 4). A substantial increase in apothecia numbers occurred at the end of April at $575 \mathrm{dd}$ ( \pm 65 ), and from May 4th to May 18th (705-902 dd) apothecia developed in all plots. Maximum apothecia production was after 600-900 dd from March 1st (Fig. 1d), but due to high variation between plots, no significant difference in apothecia numbers were observed between the different warming treatments. By experimental warming of soil temperature $2{ }^{\circ} \mathrm{C}$ above ambient, 600-900 dd was reached 5.8-7.1 days earlier. While dd from sowing or from March 1st had a weak influence on apothecia production in spring, the increase in the average number of apothecia per plot was closer related to accumulated precipitation from March 1st $\left(r^{2}=0.93, P<0.001\right)$ and daily average air temperature on the days of counting $\left(r^{2}=0.39, P=0.002\right)$.

\section{Effects of experimental warming on infection with} L. maculans in the field

Significant differences in phoma leaf spot development between the different warming treatments were not recorded in November 2010, whereas in November 2011 the number of leaf spots per plant in unheated plots was significantly elevated compared with the T2 plots (data not shown). With increased dd from sowing, less phoma leaf spots developed on SEM $\left(r^{2}=0.39\right.$, $P=0.001)$ and Falcon $\left(r^{2}=0.26, P=0.01\right)$ in both years

Crown canker development in spring showed a linear growth (Fig. 1e), starting at $300 \mathrm{dd}$ from March 1st (Table S1), which equals 1000-1200 dd after leaf spot assessment, or 1500-1900 dd from sowing in 2011 and 2012, respectively. Disease severity in terms of VDT in

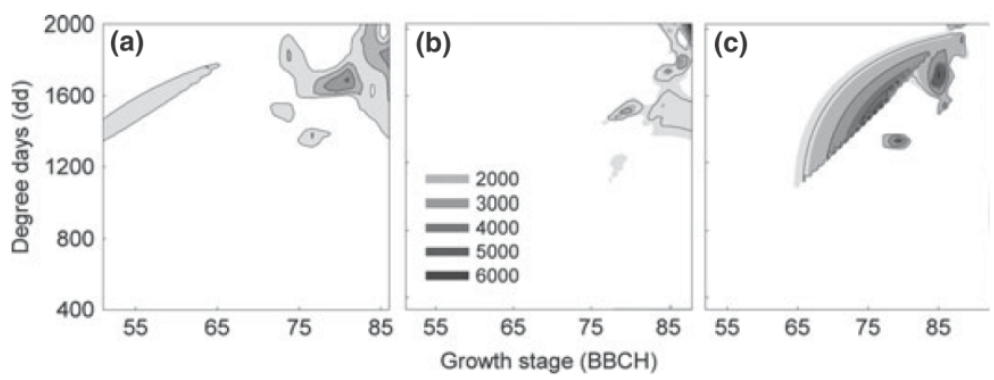

Fig. 3 Colonization of oilseed rape cultivars Heros in the climate chamber experiments (a) and SEM (b) and Falcon (c) in the field experiments 2010/11 and 2011/12 with Verticillium longisporum (ng DNA/g dry weight) in relation to degree-days $>0{ }^{\circ} \mathrm{C}$ from March 1 st and growth stage $(\mathrm{BBCH})$. 
Table 4 Spearman correlation coefficients $\left(r_{\mathrm{s}}\right)$ between accumulated degree-days $(\mathrm{dd})>0{ }^{\circ} \mathrm{C}$ during three time periods (from day of sowing, December 1st, and March 1st, until sampling and disease severity parameters of Verticillium longisporum $(V l)$ and L. maculans ( $L m$ ) in the field experiments 2010/11 and 2011/12 (all significant for $P<0.05$ ). VDT, volume of diseased tissue

\begin{tabular}{llll}
\hline Disease severity & $\begin{array}{l}\text { dd from } \\
\text { sowing }\end{array}$ & $\begin{array}{l}\text { dd from } \\
\text { Dec 1st }\end{array}$ & $\begin{array}{l}\text { dd from } \\
\text { Mar 1st }\end{array}$ \\
\hline$V l$-DNA stem SEM & 0.78 & 0.88 & 0.90 \\
$V l$-DNA stem Falcon & 0.76 & 0.87 & 0.90 \\
$L m$ root VDT SEM & 0.51 & 0.61 & 0.64 \\
$L m$ root VDT Falcon & 0.50 & 0.63 & 0.70 \\
\hline
\end{tabular}

Table 5 Average number of apothecial primordia of Sclerotinia sclerotiorum per pot in the five climate chambers at three sampling time points. Degree-days for each time point and each chamber are shown in brackets (average of two repetitions). Different letters within columns indicate significant differences between chambers $(P<0.05)$

\begin{tabular}{llll}
\hline & \multicolumn{2}{l}{ Mean number of primordia/pot after } \\
\cline { 2 - 4 } & 7 weeks & 11 weeks & 15 weeks \\
\hline Chamber 1 & $0.55^{\mathrm{b}}(384)$ & $3.72^{\mathrm{ab}}(733)$ & $3.45^{\mathrm{a}}(1180)$ \\
Chamber 2 & $1.36^{\mathrm{ab}}(437)$ & $3.00^{\mathrm{ab}}(835)$ & $1.36^{\mathrm{b}}(1338)$ \\
Chamber 3 & $1.64^{\mathrm{ab}}(512)$ & $6.18^{\mathrm{a}}(964)$ & $0.73^{\mathrm{b}}(1523)$ \\
Chamber 4 & $2.64^{\mathrm{a}}(613)$ & $7.18^{\mathrm{ab}}(1119)$ & $0.55^{\mathrm{b}}(1734)$ \\
Chamber 5 & $3.00^{\mathrm{a}}(714)$ & $2.14^{\mathrm{b}}(1274)$ & $0^{\mathrm{b}}(1945)$ \\
\hline
\end{tabular}

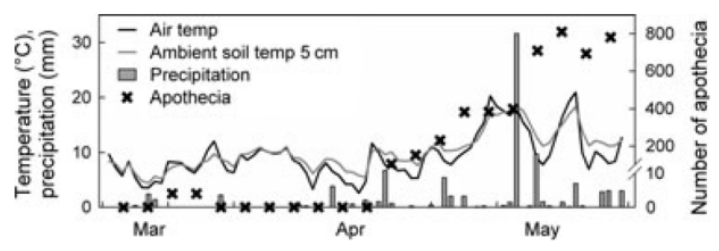

Fig. 4 Development of total number of Sclerotinia sclerotiorum apothecia in all warming treatments at the soil warming experiment, Göttingen, and weather data in spring 2012.

spring was more closely related to dd from March 1st than dd from sowing time or from December 1st (Table 4).

In 2011, Falcon showed significantly stronger symptoms than SEM for all sampling time points. In June, crown canker was more severe in the T plots, particularly for Falcon, whereas at the beginning of July, the VDT was significantly higher in the T2 plots compared with the T plots for both cultivars. Similarly, scorings in April 2012 showed significantly stronger symptoms on Falcon than on SEM, and in May and June 2012 significantly stronger symptoms were found in $T$ plots compared with the T1 and T2 plots. Overall, canker symptoms were less strong in 2012 than in 2011 (highest scores were 4.4 in 2012 compared to 6 in 2011), which corresponded to leaf symptom development in the preceding fall seasons. A higher number of phoma leaf spots in fall 2010 was associated with higher crown canker severity in June $2011\left(r^{2}=0.20, P=0.002\right)$, but this relationship could not be established between leaf spots in fall 2011 and crown canker severity in June 2012.

\section{Discussion}

\section{Plant responses to experimental warming}

Data from the climate chamber and soil warming experiments were integrated to elucidate effects of anticipated regional warming scenarios for air and soil temperature by 2050 (mid-term) and 2100 (long-term) on crop growth and pathogen development. The data integration was enabled using a thermal time scale based on accumulated degree-days (dd) $>0{ }^{\circ} \mathrm{C}$ in fall, winter and spring, allowing for direct comparison of results from both experimental approaches and different sampling time points.

Previous work reported a phenological advance of crop growth stages in spring, especially flowering, by 2.5-4.3 days per $1{ }^{\circ} \mathrm{C}$ temperature increase in the preceding months (Menzel et al., 2006; Estrella et al., 2007), which is supported by the present results on oilseed rape. The phenological advance with increasing dd from March 1st was clearer for both cultivars in the field experiment than for the spring oilseed rape cultivar Heros in the climate chambers, which may be due to the supraoptimal temperature in the warmest chamber. This is in agreement with previous studies on another spring oilseed rape cultivar (Morrison et al., 1989). Lower coefficients of correlation for temperature effects on plant height in the field compared with climate chambers may be explained by the occurrence of frost damage in 2012 which delayed the onset of shoot elongation in spring after an insufficient hardening phase for the crop immediately before the frost event. Consequently, an increasing number of degree-days due to global warming may lead to prolonged growing seasons in areas where oilseed rape cultivation is currently restricted by low temperatures (Peltonen-Sainio et al., 2009, 2011). Earlier flowering by 1-2 weeks may influence the pesticide spraying schedule of farmers accordingly. However, year to year variation in weather conditions may cause similar shifts, as observed for the flowering delay by 1 week due to late frost in 2012 .

Previous experiments on the effects of rising temperatures due to global warming mainly focused on growth and physiology of oilseed rape under 
controlled conditions (Clausen et al., 2011; Qaderi et al., 2012). This study, however, demonstrated that rising air and soil temperatures may not only enhance plant growth and advance the phenological development, but may also shift the coincidence of critical stages of fungal pathogens with crop development.

\section{Warming effects on infection with $V$. longisporum}

Soil temperature was reported as the main factor influencing the course of infection of oilseed rape by $V$. dahliae (Donald \& Czeslaw, 1998). In our field experiments, $\mathrm{Vl}$ colonization of the cultivars Falcon and SEM increased with increasing dd from March 1st. However, it is possible that thermal time in fall and winter are important to trigger microsclerotia germination and influence the subsequent time point of infection. After all, it is still not clear in which plant growth stage infection is taking place in the field. Data from $\mathrm{Vl}$-DNA analyses indicate that $V l$ is not spreading in the plants before the flowering stages in May, but the fungus may already colonize root and hypocotyl tissues during fall or winter.

It was suggested previously that pathogen latency periods may change with warming, as they are largely controlled by degree-days (Pariaud et al., 2009). Besides thermal time, the phenological stage of the plant was also important for initiating exponential growth of $\mathrm{Vl}$ in our climate chamber and field experiments, with $1300-1500 \mathrm{dd}$ in spring and $\mathrm{BBCH} 74 / 75$ being the optimal conditions. This supports the hypothesis that metabolic changes from vegetative to generative growth may induce fungal spread in the shoot (Riediger, 2008). The lower disease incidence and severity in 2012 than in 2011 may be due to higher plant losses of infected plants after harsh winter frost and the delay in phenological development in spring.

Overall, cultivar effects on $\mathrm{Vl}$ colonization were larger than effects of experimental warming. In a susceptible cultivar like Falcon, however, warming may lead to earlier and more severe stem colonization compared to ambient conditions, as measured in the field experiment in July 2011. Hence, breeding for resistant cultivars may become even more important under future warming. Although significant yield reduction is expected to occur only above $60 \%$ disease incidence (Dunker et al., 2008) enhanced colonization of root and hypocotyl may increase postharvest inoculum in the soil and cause more disease in the following years.

\section{Warming effects on apothecia development of} S. sclerotiorum

Low correlation coefficients between dd and the production of apothecial primordia in climate chambers and of apothecia in the field indicate that factors other than accumulated average temperatures seem to be crucial to provide an optimal microclimate for apothecia production, such as minimum air and soil temperature, relative humidity, and precipitation. In addition, the appearance of apothecia depends on size and burial depth of sclerotia and isolate-specific requirements for conditioning (Huang \& Kozub, 1991; Dillard et al., 1995). Apothecia production in the field in spring 2012 required average air and soil temperatures above $10{ }^{\circ} \mathrm{C}$, and was triggered by precipitation $>5 \mathrm{~mm}$ which is in agreement with previous reports (Krüger, 1975; Nordin et al., 1992; Kluge et al., 1999; Koch et al., 2007). Clarkson et al. (2004) used thermal time to forecast apothecia production in the field with upper and lower temperature thresholds of 5 and $16^{\circ} \mathrm{C}$, and a water potential of $\geq-200 \mathrm{kPa}$, suggesting that warmer temperatures and dry soil are limiting conditions. Our data from the climate chamber experiments indicate that warming by $2{ }^{\circ} \mathrm{C}$ above ambient may advance carpogenic germination in spring by around 5-7 days. As flowering of oilseed rape may be advanced accordingly, the coincidence between mid to end of flowering and ascospore release of S. sclerotiorum apothecia would still be maintained under future warming. Hence, providing conditions for infection are favorable, e.g., 23 continuous hours of $>11^{\circ} \mathrm{C}$ and $>80 \%$ rel. humidity (Koch et al., 2007), the risk of infection may remain constant under future warming, in agreement with West et al. (2012), but may be advanced earlier in the season by about 1 week. Nevertheless, apothecia production remains hard to predict as it does not show a linear response to rising temperature and depends on multiple microclimatic factors such as soil moisture, relative humidity, precipitation and air temperature close to the soil surface (Teo et al., 1989).

\section{Warming effects on disease severity induced by L. maculans}

Differences in phoma crown rot development between the warming treatments were not always significant depending on the sampling time point, as seen for crown canker in May and July 2011. Toscano-Underwood et al. (2003) used thermal time to estimate the first major release of ascospores from mature pseudothecia on wet oilseed rape debris, which may occur at $420 \mathrm{dd}\left(>0{ }^{\circ} \mathrm{C}\right)$ and cause first leaf lesions. First stem and crown canker symptoms were found 1097-1386 dd after onset of leaf spot development, depending on cultivar resistance (Evans et al., 2008). These observations match with crown canker symptoms recorded in this study at 1000-1200 dd after leaf spot assessment. 
Stonard et al. (2010) suggested that thermal time accumulation after onset of leaf spotting in fall may be a key factor in predicting severity of phoma stem and crown canker. Although systemic growth of the fungus from leaf lesions through the petioles into the stem has been reported as important route for stem and crown canker development in the following spring (West et al., 2001), correlations between the amount of phoma leaf spots and canker development have not always been confirmed (Steed et al., 2007). In this study, increased crown canker after higher leaf spot development was only found in 2010/11 but not in 2011/12. In addition, correlations of phoma crown canker severity with dd in spring were stronger than with dd from the day of sowing or December 1st. This suggests that, once successful infection has taken place in fall, other factors play an important role for systemic growth and stem canker development, particularly frost events leading to leaf shedding. Since several months pass between leaf spot and canker development, frost events may not always be reflected in degree-day accumulation, even if lower threshold temperatures are used for calculation. The limited importance of degreeday accumulation for crown canker development under climatic conditions in Göttingen may explain the high scattering of disease severity levels among replicates within one treatment. Furthermore, weaker leaf spot development in fall 2011 was associated with higher soil and air degree-days on the one hand, but less precipitation on the other hand (Table S2), underlining the importance of moisture.

\section{Use of degree-days in warming experiments}

To our knowledge, this study is the first approach which utilized degree-days based on a combination of soil and air temperatures. Projections based on elevated soil temperature may be particularly important for soiland debris-borne pathogens, as global warming will also lead to rising soil temperatures (Amthor et al., 2010). While the degree-day concept is useful when comparing different studies on temperature effects, the use of different definitions and calculations of dd, particularly concerning different baseline temperatures, may be a limitation for comparison of different studies (Bonhomme, 2000). The suitable baseline temperature may vary between cultivars (Morrison et al., 1989), plant growth stages, life cycle stages of pathogens, and the environment where a particular life cycle stage is taking place (Lovell et al., 2004). In this study, which focused on both plant growth and pathogen development as affected by air and soil temperature, a baseline temperature of $0{ }^{\circ} \mathrm{C}$ proved adequate for establishing relationships based on degree-days.
In general, our experimental results based on degreedays match the estimations based on cardinal temperatures for the different life cycle stages of the three fungal pathogens (Siebold \& von Tiedemann, 2012a). However, the nonlinear response of pathogens toward increasing temperature often limits the use of average temperatures, especially with temperatures close to the optimum of the pathogens (Scherm \& van Bruggen, 1994). Furthermore, increasing climatic variability (Garrett et al., 2013) and extreme weather events (Rosenzweig et al., 2001) may have a bigger effect on fungal pathogen development than increases in average temperatures. Depending on the period for which degree-days are calculated, temperature variability and extremes may or may not be reflected, which could explain the better correlation of disease parameters measured in the field with dd calculated from March 1st than dd from day of sowing or December 1st. Upper and lower temperature limits depend on the life cycle stage of the pathogen, and the length of a specific life cycle stage is influenced by multiple climatic factors. Estimations on future pathogen prevalence based on a combination of the cardinal temperature and the degree-day approach may be more robust than estimations based on a single approach.

\section{Estimated pathogen prevalence in Lower Saxony under future warming}

Differences in disease development between ambient and warming treatments were not significant for all sampling time points using ANOVA analyses, which may be due to the limited number of replicates per warming treatment and sampled plants within one replicate. The regression approach, however, demonstrated whether increased thermal time had an overall influence on fungal disease progress and identified critical thermal times in pathogen epidemiology, which may be utilized in theoretical or practical disease forecasting models. Under a $+2{ }^{\circ} \mathrm{C}$ warming scenario, the optimum thermal time of $600-900$ dd from March 1st for sclerotia germination of $S$. sclerotiorum may be advanced by 1 week, coinciding with premature flowering, potentially requiring earlier fungicide application by farmers. Whereas a warmer spring may be particularly favorable for plant growth and S. sclerotiorum, warmer summers may particularly favor $V$. longisporum. Colonization of oilseed rape stems by $V$. longisporum which requires 1300-1500 dd from March 1st may be advanced by 7-9 days, potentially leading to higher inoculum densities on stubble after harvest. Since resistant cultivars are not available for farmers until today, $V$. longisporum may become even more important under future warming. Results for L. maculans were not 
consistent, and relative humidity in fall and less leaf shedding of plants over winter may be more important for canker development than direct temperature effects, at least in regions with climatic conditions comparable to Göttingen. The critical degree-days established in this study need to be validated by future field experiments at different locations. Furthermore, multiple climatic factors should be studied in future manipulation experiments, which are an important supplement for outputs of regional climate-crop-disease models.

\section{Acknowledgements}

This work was funded by the Ministry for Science and Culture of Lower Saxony, Germany, within the research network 'KLIFF - climate impact and adaptation research in Lower Saxony'. We thank Hans-Peter Suck (ADS Networks, Bad Homburg, Germany) for his support during development and installation of the soil warming facility. Furthermore, we are grateful to Frank Gremmes and Marc Fiebrich for technical support and maintenance of the field experimental facility, as well as to Hubertus Reintke for agronomic support.

\section{References}

Amthor JS, Hanson PJ, Norby RJ, Wullschleger SD (2010) A comment on "Appropriate experimental ecosystem warming methods by ecosystem, objective, and practicality" by Aronson and McNulty. Agricultural and Forest Meteorology, 150, 497-498.

Analytis S (1977) On the relation between temperature and biological response of some plant pathogenic fungi. Journal of Phytopathology, 90, 64-76. (German with English Abstract).

Bonhomme R (2000) Bases and limits to using 'degree.day' units. European Journal of Agronomy, 13, 1-10

Brandfass C, Karlovsky P (2006) Simultaneous detection of Fusarium culmorum and F. graminearum in plant material by duplex PCR with melting curve analysis. BMC Microbiology, 6, 4 .

Butterworth MH, Semenov MA, Barnes A, Moran D, West IS, Fitt BDL (2010) NorthSouth divide: contrasting impacts of climate change on crop yields in Scotland and England. Journal of The Royal Society Interface, 7, 123-130.

Cheng L, Booker FL, Burkey KO et al. (2011) Soil microbial responses to elevated $\mathrm{CO}_{2}$ and $\mathrm{O}_{3}$ in a nitrogen-aggrading agroecosystem. PLoS ONE, 6, e21377. doi: 10.1371/ journal.pone. 0021377

Clarkson JP, Phelps K, Whipps JM, Young CS, Smith JA, Watling M (2004) Forecasting Sclerotinia disease on lettuce: toward developing a prediction model for carpogenic germination of sclerotia. Phytopathology, 94, 268-279.

Clausen SK, Frenck G, Linden LG, Mikkelsen TN, Lunde C, Jørgensen RB (2011) Effects of single and multifactor treatments with elevated temperature, $\mathrm{CO}_{2}$ and ozone on oilseed rape and barley. Journal of Agronomy and Crop Science, 197, $442-453$.

Colhoun J (1973) Effects of environmental factors on plant disease. Annual Review of Phytopathology, 11, 343-364.

Dillard HR, Ludwig JW, Hunter JE (1995) Conditioning sclerotia of Sclerotinia sclerotiorum for carpogenic germination. Plant Disease, 79, 411-415.

Donald Z, Czeslaw S (1998) Effect of temperature on infestation and development of Verticillium dahliae Kleb. on winter oilseed rape. IOBC/wprs Bulletin, 21, 41-47.

Dunker S, Keunecke H, Steinbach P, von Tiedemann A (2008) Impact of Verticillium longisporum on yield and morphology of winter oilseed rape (Brassica napus) in relation to systemic spread in the plant. Journal of Phytopathology, 156, 698-707.

Eastburn DM, McElrone AJ, Bilgin DD (2011) Influence of atmospheric and climatic change on plant-pathogen interactions. Plant Pathology, 60, 54-69.

Estrella N, Sparks TH, Menzel A (2007) Trends and temperature response in the phenology of crops in Germany. Global Change Biology, 13, 1737-1747.

Evans N, Baierl A, Gladders P, Hall B, Fitt BDL (2006) Prediction of the date of onset of Phoma leaf spot epidemics on oilseed rape in the UK. IOBC/wprs Bulletin, 29, 287-292.
Evans N, Baierl A, Semenov MA, Gladders P, Fitt BDL (2008) Range and severity of a plant disease increased by global warming. Journal of The Royal Society Interface, 5, 525-531.

Evans N, Butterworth M, Baierl A et al. (2010) The impact of climate change on disease constraints on production of oilseed rape. Food Security, 2, 143-156.

Eynck C, Koopmann B, Grunewaldt-Stoecker G, Karlovsky P, von Tiedemann A (2007) Differential interactions of Verticillium longisporum and $V$. dahliae with Brassica napus detected with molecular and histological techniques. European Iournal of Plant Pathology, 118, 259-274.

Eynck C, Koopmann B, von Tiedemann A (2009) Identification of Brassica accessions with enhanced resistance to Verticillium longisporum under controlled and field conditions. Journal of Plant Diseases and Protection, 116, 63-72.

Figueroa L, Fitt BDL, Welham SJ, Shaw MW, McCartney HA (1995) Early development of light leaf spot (Pyrenopeziza brassicae) on winter oilseed rape (Brassica napus) in relation to temperature and leaf wetness. Plant Pathology, 44, 641-654.

Fitt BDL, Brun H, Barbetti MJ, Rimmer SR (2006) World-wide importance of Phoma stem canker (Leptosphaeria maculans and L. biglobosa) on oilseed rape (Brassica napus). European Journal of Plant Pathology, 114, 3-15.

Garrett KA, Dobson ADM, Kroschel J, Natarajan B, Orlandini S, Tonnang HEZ, Valdivia C (2013) The effects of climate variability and the color of weather time series on agricultural diseases and pests, and on decisions for their management. Agricultural and Forest Meteorology, 170, 216-227.

Haberlandt U, Belli A, Hölscher J (2010) Trends in beobachteten Zeitreihen von Temperatur und Niederschlag in Niedersachsen. Hydrologie und Wasserberwirtschaftung, 54, 28-36. (German with English Abstract).

$\mathrm{Hu}$ Q, Feng S (2003) A daily soil temperature dataset and soil temperature climatology of the contiguous United States. Journal of Applied Meteorology, 42, 1139-1156.

Huang HC, Kozub GC (1991) Temperature requirements for carpogenic germination of sclerotia of Sclerotinia sclerotiorum isolates of different geographic origin. Botanical Bulletin of Academia Sinica, 32, 279-286.

Juroszek P, von Tiedemann A (2012) Plant pathogens, insect pests and weeds in a changing global climate: a review of approaches, challenges, research gaps, key studies and concepts. The Journal of Agricultural Science, doi: 10.1017/ S0021859612000500

Karl TR, Trenberth KE (2003) Modern global climate change. Science, 302, 1719-1723. Keunecke $\mathrm{H}$ (2009) Impact of cabbage root fly on infections and damage potential of Verticillium longisporum and Phoma lingam in oilseed rape. PhD thesis, GeorgAugust-University Göttingen, pp. 231.

Kimball BA, Conley MM (2009) Infrared heater arrays for warming field plots scaled up to 5-m diameter. Agricultural and Forest Meteorology, 149, 721-724.

Kluge E, Enzian S, Gutsche V (1999) Weißstängeligkeit an Winterraps (Sclerotinia sclerotiorum (Lib.) de Bary). In: Atlas der Potentiellen Befallsgefährdung Durch Wichtige Schadorganismen im Ackerbau Deutschlands (ed. Biologische Bundesanstalt für Landund Forstwirtschaft,), pp. 103-105. Saphir-Verlag, Ribbesbüttel.

Koch S, Dunker S, Kleinhenz B, Rohrig M, von Tiedemann A (2007) Crop loss-related forecasting model for Sclerotinia stem rot in winter oilseed rape. Phytopathology, 97, 1186-1194.

Krüger W (1975) Die Beeinflussung der Apothezien- und Ascosporen-Entwicklung des Rapskrebserregers Sclerotinia sclerotiorum (Lib.) de Bary durch Umweltfaktoren. Journal of Plant Diseases and Protection, 82, 101-108. (German).

Lancashire PD, Bleiholder $\mathrm{H}$, Boom TVD, Langelüddeke P, Stauss R, Weber E, Witzenberger A (1991) A uniform decimal code for growth stages of crops and weeds. Annals of Applied Biology, 119, 561-601.

Lovell DJ, Powers SJ, Welham SJ, Parker SR (2004) A perspective on the measurement of time in plant disease epidemiology. Plant Pathology, 53, 705-712

Menzel A, Sparks TH, Estrella N et al. (2006) European phenological response to climate change matches the warming pattern. Global Change Biology, 12, 1969-1976. Morrison MJ, McVetty PBE, Shaykewich CF (1989) The determination and verification of a baseline temperature for the growth of Westar summer rape. Canadian Journal of Plant Science, 69, 455-464.

Mortensen LM, Strømme E (1987) Effects of light quality on some greenhouse crops. Scientia Horticulturae, 33, 27-36

Nordin K, Sigvald R, Svensson C (1992) Forecasting the incidence of Sclerotinia stem rot on spring-sown rapeseed. Journal of Plant Diseases and Protection, 99, 245-255.

Pariaud B, Ravigné V, Halkett F, Goyeau H, Carlier J, Lannou C (2009) Aggressiveness and its role in the adaptation of plant pathogens. Plant Pathology, 58, 409-424. Parmesan C (2007) Influences of species, latitudes and methodologies on estimates of phenological response to global warming. Global Change Biology, 13, 1860-1872.

Patil RH, Laegdsmand M, Olesen JE, Porter JR (2010) Growth and yield response of winter wheat to soil warming and rainfall patterns. The Journal of Agricultural Science, 148, 553-566. 


\section{M. SIEBOLD \& A. VON TIEDEMANN}

Pau S, Wolkovich EM, Cook BI et al. (2011) Predicting phenology by integrating ecology, evolution and climate science. Global Change Biology, 17, 3633-3643.

Peltonen-Sainio P, Hakala K, Jauhiainen L, Ruosteenoja K (2009) Comparing regional risks in producing turnip rape and oilseed rape - Impacts of climate change and breeding. Acta Agriculturæ Scandinavica Section B, 59, 129-138.

Peltonen-Sainio P, Jauhiainen L, Hakala K (2011) Crop responses to temperature and precipitation according to long-term multi-location trials at high-latitude conditions. The Journal of Agricultural Science, 149, 49-62

Potter TI, Rood SB, Zanewich KP (1999) Light intensity, gibberellin content and the resolution of shoot growth in Brassica. Planta, 207, 505-511.

Qaderi MM, Kurepin LV, Reid DM (2012) Effects of temperature and watering regime on growth, gas exchange and abscisic acid content of canola (Brassica napus) seedlings. Environmental and Experimental Botany, 75, 107-113.

Regierungskommision Klimaschutz (2012) Empfehlung für Eine Niedersächsische Strategie zur Anpassung an die Folgen des Klimazandels. Niedersächsisches Ministerium für Umwelt, Energie und Klimaschutz, Hanover.

Riediger N (2008) Beteiligung systemischer Signale an der Symptomauslösung bei Brassica napus nach Infektion mit Verticillium longisporum und $V$, dahliae. $\mathrm{PhD}$ thesis, Georg-August University Göttingen, pp. 184

Rosenzweig C, Iglesias A, Yang XB, Epstein PR, Chivian E (2001) Climate change and extreme weather events: implications for food production, plant diseases, and pests. Global Change and Human Health, 2, 90-104.

Scherm H, van Bruggen AHC (1994) Global warming and nonlinear growth: how important are changes in average temperature? Phytopathology, 84, 1380 1384.

Schwartz MD, Ahas R, Aasa A (2006) Onset of spring starting earlier across the Northern Hemisphere. Global Change Biology, 12, 343-351.

Siebold M, von Tiedemann A (2012a) Potential effects of global warming on oilseed rape pathogens in Northern Germany. Fungal Ecology, 5, 62-72

Siebold M, von Tiedemann A (2012b) Application of a robust experimental method to study soil warming effects on oilseed rape. Agricultural and Forest Meteorology, 164 20-28.

Stadler M (2010) Entwicklung eines Verfahrens zum biologischen Abbau des Inokulums strohbürtiger pilzlicher Pathogene im Getreide- und Rapsanbau auf Basis des pilzlichen Antagonisten Microsphaeropsis ochracea. PhD thesis, Georg-August University Göttingen, pp. 168.

Steed J, Baierl A, Fitt B (2007) Relating plant and pathogen development to optimise fungicide control of phoma stem canker (Leptosphaeria maculans) on winter oilseed rape (Brassica napus). European Journal of Plant Pathology, 118, 359-373.

Stonard JF, Marchant BP, Latunde-Dada AO et al. (2010) Geostatistical analysis of the distribution of Leptosphaeria species causing phoma stem canker on winter oilseed rape (Brassica napus) in England. Plant Pathology, 59, 200-210.

Stone PJ, Sorensen IB, Jamieson PD (1999) Effect of soil temperature on phenology, canopy development, biomass and yield of maize in a cool-temperate climate. Field Crops Research, 63, 169-178.

Teo BK, Morrall RAA, Verma PR (1989) Influence of soil moisture, seedling date, and canola cultivars (Tobin and Westar) on the germination and rotting of sclerotia of Sclerotinia sclerotiorum. Canadian Journal of Plant Pathology, 11, 393-399. von Tiedemann A (1996) Global atmospheric and climate change - what are the implications for plant protection? Nachrichtenblatt des Deutschen Pflanzenschutzdienstes, 48, 73-79. (German with English Abstract).

Toscano-Underwood C, Huang YJ, Fitt BDL, Hall AM (2003) Effects of temperature on maturation of pseudothecia of Leptosphaeria maculans and L. biglobosa on oilseed rape stem debris. Plant Pathology, 52, 726-736.

Tuck G, Glendining MJ, Smith P, House JI, Wattenbach M (2006) The potential distribution of bioenergy crops in Europe under present and future climate. Biomass and Bioenergy, 30, 183-197.

Van der Velde M, Bouraoui F, Aloe A (2009) Pan-European regional-scale modelling of water and $\mathrm{N}$ efficiencies of rapeseed cultivation for biodiesel production. Global Change Biology, 15, 24-37.

Weigel HJ (2005) Healthy plants in the future: how does climate change affect crop production? Gesunde Pflanzen, 57, 6-17. (German with English Abstract),

West JS, Kharbanda PD, Barbetti MJ, Fitt BDL (2001) Epidemiology and management of Leptosphaeria maculans (phoma stem canker) on oilseed rape in Australia, Canada and Europe. Plant Pathology, 50, 10-27.

West JS, Townsend JA, Stevens M, Fitt BDL (2012) Comparative biology of different plant pathogens to estimate effects of climate change on crop diseases in Europe. European Journal of Plant Pathology, 133, 315-331.

Xiao G, Zhang Q, Li Y, Wang R, Yao Y, Zhao H, Bai H (2010) Impact of temperature increase on the yield of winter wheat at low and high altitudes in semiarid northwestern China. Agricultural Water Management, 97, 1360-1364.

Zeise K, Seidel D (1990) Zur Entwicklung und Schadwirkung der VerticilliumWelkekrankheit am Winterraps. Raps, 8, 20-22. (German).

Zhang Y, Chen W, Smith SL, Riseborough DW, Cihlar J (2005) Soil temperature in Canada during the twentieth century: complex responses to atmospheric climate change. Journal of Geophysical Research, 110, D03112, doi: 10.1029/2004JD004910

\section{Supporting Information}

Additional Supporting Information may be found in the online version of this article:

Table S1. Degree-days $>0{ }^{\circ} \mathrm{C}$ from March 1st in the climate chamber (mean \pm SD of two experiments) and field experiments (mean $\pm \mathrm{SD}$ of four replicates for each individual year). $\mathrm{T}=$ ambient plots, $\mathrm{T} 1=+1.6{ }^{\circ} \mathrm{C}, \quad \mathrm{T} 2=+3.2{ }^{\circ} \mathrm{C}$. n.a $=$ not applicable

Table S2. Monthly degree-days $>0{ }^{\circ} \mathrm{C}$ for soil temperature in $5 \mathrm{~cm}$ depth (mean of four replicates per treatment), air temperature, and monthly precipitation (Prec.) for the two field experiments $2010 / 11$ and $2011 / 12 . \mathrm{T}=$ ambient plots, $\mathrm{T} 1=+1.6{ }^{\circ} \mathrm{C}, \mathrm{T} 2=+3.2{ }^{\circ} \mathrm{C}$. 


\section{Chapter 5: General Discussion}

\section{Use of cardinal temperatures and degree days in climate change studies}

This work presents for the first time possible effects of global warming on important pathogens of oilseed rape in Germany, derived from a combination of theoretical and experimental approaches. The theoretical approach was based on cardinal temperatures for each life cycle stage of the pathogens Phoma lingam (Leptosphaeria maculans), Sclerotinia sclerotiorum, Verticillium longisporum, Pyrenopeziza brassicae and Alternaria sp. By comparing those temperature requirements with regional climate projections for three different oilseed rape growing regions in Lower Saxony, it was estimated that $V$. longisporum, S. sclerotiorum and Alternaria sp. may be favored by rising temperatures, particularly during initial life cycle stages, whereas $P$. lingam is in its optimum temperature range already at most locations, and $P$. brassicae may lose importance under future warming. From the experimental approaches based on accumulated degree days in spring it was concluded that warming may advance spread of $V$. longisporum inside the stem potentially leading to stronger colonization, and lead to earlier apothecia production of S. sclerotiorum potentially advancing the infection window, whereas results on $P$. lingam were controversial and no clear trend towards warmer temperatures could be established. In general, estimations based on cardinal temperatures match the experimental results based on degree days. Hence, the combination of both approaches was useful to assess possible impacts of warming on the development of these pathogens. For $S$. sclerotiorum, the cardinal temperature approach may be more important, since correlation coefficients for degree days were low. For $V$. longisporum, on the other hand, the degree day approach may be more applicable, since the infection time point is still not established. West et al. (2012) evaluated the outcome of weather-based disease models in the light of pathogen epidemiology and projected climate change for north-west Europe. They concluded that little change may be expected for springinfecting root and stem pathogens like S. sclerotiorum, since their development may be advanced in parallel with crop development, which agrees with our results for S. sclerotiorum under German climatic conditions.

The comparison of results based on degree days may be compromised by the use of different definitions and calculations of $\mathrm{dd}$, particularly concerning different baseline temperatures (Bonhomme 2000). For oilseed rape, a baseline temperature of $5^{\circ} \mathrm{C}$ below which no plant development takes place has often been assumed, but there are also studies suggesting a lower 
threshold temperature of $0^{\circ} \mathrm{C}$ (Cruz et al. 2007; Habekotte 1997; Hodgson 1978). The baseline temperature may also depend on the cultivar (Morrison et al. 1989) or growth stage. For fungal pathogen development, baseline temperatures of $0.5^{\circ} \mathrm{C}$ (Zearfoss et al. 2011) and $1.1^{\circ} \mathrm{C}$ (Bolton et al. 2010) have been used previously. Magarey et al. (2005) suggested minimum temperatures for leaf infection of L. maculans $\left(2.6^{\circ} \mathrm{C}\right)$ and $S$. sclerotiorum $\left(1^{\circ} \mathrm{C}\right)$ on oilseed rape and bean, respectively. Overall, the baseline temperature for a certain pathogen depends on the life cycle stage and may be strongly influenced by the environment where a particular life cycle stage is taking place, e.g. soil, air or inside the plant tissue (Lovell et al. 2004)

The linkage of climate change projections with plant disease forecast generally faces the problem of different scales, i.e. an event in the fungal life cycle may take place on a sub-daily or weekly basis, whereas future climate projections have a much larger temporal resolution (Seem 2004). Furthermore, pathogen response is often nonlinear towards temperature, and estimation errors may occur when average temperatures are close to the optimum of a certain pathogen (Scherm 2004). One may argue that this limits the use of daily mean temperatures as reflected in the degree day approach in global warming assessment, since temperatures exceeding the optimum of a fungus are not included (Schrödter 1965). However, upper and lower temperature limits are life cycle specific and the length of a specific life cycle stage is hard to predict due to influences other than temperature. By considering both the cardinal and the degree days approach, estimations on future pathogen development seem to be more robust.

\section{Experimental approaches in climate change studies}

A variety of experimental approaches, such as plastic covers, infrared heaters, open top chambers and heating elements in the soil or on the soil surface, has been used in the past to study climate change effects under field conditions in different environments. Investigations, however, mainly focused on plant species composition and diversity (Zavaleta et al. 2003), growth and phenology (Patil et al. 2010), and soil processes like soil respiration (Natali et al. 2011), C and $\mathrm{N}$ cycles (Niu et al. 2011), decomposition (Verburg et al. 1999) and microbial diversity (Sheik et al. 2011), whereas the work reported here was the first to focus on both host plant and pathogen development under experimental warming. It may be useful for future studies utilizing the soil warming facility to add above-ground sensors measuring the canopy microclimate, especially for life cycle stages of pathogens that take place on the soil surface (e.g. sporulation), and to supplement soil warming by above-ground warming or temporary 
rainout shelters, allowing multifactor climate change impact assessment. The importance of changes in future temperature variability has often been stressed, but may be difficult to study experimentally. Hence, most approaches use fixed temperature offsets between ambient and heated. Since soil-borne pathogens are seldomly included in climate change experiments, it is recommended to expand this kind of experiments.

\section{Effects of other climatic factors on pathogen development}

This work focused on elevated temperatures as a result of climate change, which are predicted by global climate models. However, other climatic factors, such as relative humidity, precipitation and soil moisture may influence certain life cycle stages of fungal pathogens to a greater extent than temperatures.

Among oilseed rape pathogens, Phoma lingam has been most extensively studied due to its high yield loss potential. Findings on P. lingam from the UK suggest that increases in thermal time may advance the onset of leaf spotting in autumn and stem canker development in the following spring, potentially leading to higher disease severity (Evans et al. 2006; Evans et al. 2008). However, cumulative daily rainfall was also included in these projections. Modeling approaches on pseudothecia maturation and subsequent ascospore release in autumn used temperature only as upper or lower limit and focused on cumulative rain days (Aubertot et al. 2006; Salam et al. 2003). Results imply that even if temperatures are conducive for pathogen development, seasonal shifts in rainfall patterns may delay the onset of phoma spore release and subsequent plant infection. Hence, in areas with a climate similar to Göttingen, where temperatures seem to be already conducive for $P$. lingam epidemics, changes in rainfall and relative humidity may have a stronger influence on future disease incidence and severity, whereas in currently colder regions, e.g the mountainous Harz region, rising autumn temperatures may additionally favor the initiation of $P$. lingam epidemics.

In this study, only sclerotia germination of S. sclerotiorum as the first step in the disease cycle was investigated. More significant for farmers, however, is the ascospore release from apothecia and subsequent stem infection. For this purpose, the decision support model SkleroPro was developed (Koch et al. 2007). It is based on favorable hours of air temperature $>7^{\circ} \mathrm{C}$ and $11^{\circ} \mathrm{C}$, and relative humidity $>86$ and $80 \%$, respectively, and a fungicide application recommendation is given after 23 continuously favorable hours. Overall, the model leads to the right decision in $70-80 \%$ of cases (Kleinhenz et al. 2006). In this system, however, apothecia production is not considered. Our results suggest that temperature may be one factor influencing timing of apothecia appearance, but may not be the main driver for 
successful apothecia production. Soil moisture and relative humidity may be more important factors for creating a microclimate favorable for successful apothecia production (Kluge et al. 1999; Mila and Yang 2008; Teo et al. 1989), but their future projections are associated with high uncertainties (Karl and Trenberth 2003).

Soil moisture may be important for germination of microsclerotia of Verticillium longisporum, growth of mycelium in the soil and subsequent infection of oilseed rape roots. Since much of its life cycle as a vascular pathogen takes place inside the plant tissue, microclimatic effects may be less important after successful infection.

\section{Changes in plant-pathogen interaction}

Rising air and soil temperatures will influence the soil microclimate. It was speculated that stimulated plant growth may lead to higher root exudation, potentially leading to enhanced pathogen growth (Pritchard 2011). In this case, microsclerotia germination of $V$. longisporum may be favored. In some situations, rising temperatures may lead to reduced soil moisture and drought stress of crops (Whitmore and Whalley 2009). Adverse effects of drought stress may be stronger than the effect of supra-optimal temperatures on canola seedlings (Qaderi et al. 2012). Plants suffering from drought stress may be more susceptible towards fungal pathogen infection (Eastburn et al. 2011). However, recent experimental findings suggest that infection of oilseed rape by $V$. longisporum may not be reduced under drought stress (Daniel Lopisso, pers. comm.). Furthermore, rising temperatures may lead to reduced host resistance. For example, Huang et al. (2006) showed that the phenotypic resistance of oilseed rape lines carrying the $R \operatorname{lm} 6$ resistance gene is reduced at temperatures of $25^{\circ} \mathrm{C}$, enabling systemic growth of $L$. maculans from leaf lesions to stems.

Increased $\mathrm{CO}_{2}$ levels and their effects on crop development have been studied extensively. They were linked to faster plant growth, increased biomass and photosynthesis rates in $\mathrm{C} 3$ plants by increased water use efficiency (Brouder and Volenec 2008; Olesen and Bindi 2002; Weigel 2005). The first FACE (free air carbon enrichment) experiment with spring oilseed rape (Franzaring et al. 2008) revealed a positive $\mathrm{CO}_{2}$ fertilization effect on plant growth before flowering, which did not result in significant increase of seed oil contents and oil yields. Furthermore, enhanced $\mathrm{CO}_{2}$ levels may lead to water saving effects due to reduced transpiration (Franzaring et al. 2011), which may countervail the drought stress effect. Few studies on $\mathrm{CO}_{2}$ effects on pathogen development have been carried out. Those effects are mainly believed to be host plant mediated effects, e.g. enhanced initial host resistance or a conducive microclimate due to enlarged plant canopy (Chakraborty 2005; Manning and 
Tiedemann 1995). Eastburn et al. (2011) stated that necrotrophic foliar pathogens may be favored by rising $\mathrm{CO}_{2}$, whereas effects on soil-borne pathogens have not yet been studied.

\section{Global warming and agricultural practices}

Farmers have been dealing with climatic variability between years successfully in the past. Thus, they are likely to cope well with future climatic change. Rising temperatures may be beneficial for farmers in Germany, since the extended growing season may allow more flexibility between harvesting and sowing. Later sowing may allow seedlings to escape advanced ascospore showers of L. maculans, or faster plant growth from unchanged sowing dates may lead to faster adult plant resistance towards systemic growth of L. maculans (Hammond and Lewis 1986). However, experiments on spring oilseed rape also suggest that supra-optimal temperatures in the seed-filling stage may limit yield (Clausen et al. 2011). Morrison and Stewart (2002) reported a reduction in flowering number and seed yield above maximum daily temperatures of $29.5^{\circ} \mathrm{C}$. This may become a problem in currently already warmer regions.

Besides fungal pathogens, insect pests are likely to be affected by warming. For example, an earlier onset of stem elongation may be accompanied by earlier emergence and a prolonged migration period of the stem weevil Ceutorhynchus pallidactylus (Junk et al. 2012) implying an adjusted future insecticide spraying schedule for farmers. Furthermore, eggs of the rape flea beetle (Psylliodes chrysocephala) may hatch earlier in autumn due to increased thermal time, which may lead to higher plant damage (Antje Reinhardt, pers. comm.). Insect damage, on the other hand, can also cause entry pathways for fungal pathogens, which is particularly important for P. lingam (Keunecke 2009). Additionally, new disease problems could arise in currently colder regions, and warmer soil conditions during winter may allow overwintering of novel pathogens (Pritchard 2011). Besides the fungal pathogens considered in this study, other pathogens may thrive under future warming, e.g. Plasmodiophora brassicae, a soilborne pathogen which has been found to a higher extend in German oilseed rape fields recently and is favored by high soil temperatures (Sharma et al. 2011), or Botrytis cinerea, a saprophyte which can lead to severe plant losses in overgrown, frost-damaged crops, as widely observed in spring 2012. Human activities can also lead to the occurrence of new pathogen strains. For example, $V$. longisporum as a supposedly recent hybrid of $V$. dahliae and two unknown species has a new host range and higher virulence on oilseed rape than any of its parents (Inderbitzin et al. 2011). 
Besides global warming, political frameworks may influence the future importance of fungal pathogens in oilseed rape. For example, the EU directive 2009/28/EC (Eur-lex 2012a) on the promotion of the use of energy from renewable sources and the national BiofuelQuotaAct (Bio-energie.de 2012), which enforces the use of biofuels to reduce greenhouse gas emissions from fossil fuels, will lead to a growing demand for oil from renewable energy resources like oilseed rape, which may be satisfied by rises in yield or cultivation area. Rising oilseed rape cultivation, however, will lead to enhanced pathogen pressure. Furthermore, an increased cultivation of sunflower, which is a host for the generalist $S$. sclerotiorum, in a mix with maize for biogas plants (Bioenergieportal 2012) may lead to inoculum accumulation in the soil (West et al. 2012). On the other hand, EU directive 2009/128/EG (Eur-lex 2012b) on the sustainable use of pesticides will enforce integrated pest management (IPM) based on the reduction of pesticide application and the use of other measures of disease control, such as crop rotation, debris management and growing resistant cultivars.

Hence, breeding for resistance may be the most important tool for future control of $S$. sclerotiorum and L. maculans, which are mainly controlled by fungicide application today, but particularly in the case of $V$. longisporum (Rygulla et al. 2007) where no other control measures exist to date. To assess plant resistance in field experiments, sampling time points at the beginning of May are recommended, since qPCR measurements at that time point enable differentiation between cultivar susceptibility without the pathogen having reached its saprophytic phase. Higher amounts of salicylic acid (see appendix) in susceptible genotypes or phenolics and lignin in tolerant genotypes (Eynck et al. 2009) may serve as additional markers for susceptibility and resistance early in the growing season. Since disease incidence and severity strongly increase before harvest, late field observations are rather unreliable for differentiating between cultivar resistance (Johansson et al. 2006).

Concluding, global warming will be one of many stimuli influencing future oilseed rape cultivation and pathogen prevalence. 


\section{References}

Aubertot JN, Salam MU, Diggle AJ, Dakowska S and Jedryczka M (2006). SimMat, a new dynamic module of Blackleg Sporacle for the prediction of pseudothecial maturation of L.maculans/L.biglobosa species complex. Parameterisation and evaluation under Polish conditions. IOBC/wprs Bulletin 29(7): 277-285.

Bio-energie.de (2012). http://www.bioenergie.de/rahmenbedingungen/gesetzeslage/biokraftstoff-quotengesetz/ (verified 05.09.2012)

Bioenergieportal (2012). http://www.bioenergieportal.info/bayern/energiepflanzen/sonnenblume/ (verified 08.09.2012)

Bolton MD, Panella L, Campbell L and Khan MFR (2010). Temperature, moisture, and fungicide effects in managing Rhizoctonia root and crown rot of sugar beet. Phytopathology 100(7): 689-697.

Bonhomme R (2000). Bases and limits to using 'degree.day' units. European Journal of Agronomy 13(1): 1-10.

Brouder SM and Volenec JJ (2008). Impact of climate change on crop nutrient and water use efficiencies. Physiologia Plantarum 133(4): 705-724.

Chakraborty S (2005). Potential impact of climate change on plant-pathogen interactions. Australasian Plant Pathology 34(4): 443-448.

Clausen SK, Frenck G, Linden LG, Mikkelsen TN, Lunde C and Jørgensen RB (2011). Effects of single and multifactor treatments with elevated temperature, $\mathrm{CO}_{2}$ and ozone on oilseed rape and barley. Journal of Agronomy and Crop Science 197(6): 442-453.

Cruz VMV, Luhman R, Marek LF, Rife CL, Shoemaker RC, Brummer EC and Gardner CAC (2007). Characterization of flowering time and SSR marker analysis of spring and winter type Brassica napus L. germplasm. Euphytica 153(1-2): 43-57.

Eastburn DM, McElrone AJ and Bilgin DD (2011). Influence of atmospheric and climatic change on plant-pathogen interactions. Plant Pathology 60(1): 54-69.

Eur-lex (2012a). http://eur-

lex.europa.eu/LexUriServ/LexUriServ.do?uri=Oj:L:2009:140:0016:0062:en:PDF

Eur-lex (2012b). http://eur-

lex.europa.eu/LexUriServ/LexUriServ.do?uri=OJ:L:2009:309:0071:0086:DE:PDF

Evans N, Baierl A, Gladders P, Hall B and Fitt BDL (2006). Prediction of the date of onset of Phoma leaf spot epidemics on oilseed rape in the UK. IOBC/wprs Bulletin 29(7): 287292. 
Evans N, Baierl A, Semenov MA, Gladders P and Fitt BDL (2008). Range and severity of a plant disease increased by global warming. Journal of The Royal Society Interface 5(22): 525-531.

Eynck C, Koopmann B, Karlovsky P and Tiedemann Av (2009). Internal resistance in winter oilseed rape inhibits systemic spread of the vascular pathogen Verticillium longisporum. Phytopathology 99(7): 802-811.

Franzaring J, Högy P and Fangmeier A (2008). Effects of free-air $\mathrm{CO}_{2}$ enrichment on the growth of summer oilseed rape (Brassica napus cv. Campino). Agriculture, Ecosystems \& Environment 128(1-2): 127-134.

Franzaring J, Weller S, Schmid I and Fangmeier A (2011). Growth, senescence and water use efficiency of spring oilseed rape (Brassica napus L. cv. Mozart) grown in a factorial combination of nitrogen supply and elevated $\mathrm{CO}_{2}$. Environmental and Experimental Botany 72(2): 284-296.

Habekotte B (1997). A model of the phenological development of winter oilseed rape (Brassica napus L.). Field Crops Research 54(2-3): 127-136.

Hammond KE and Lewis BG (1986). The timing and sequence of events leading to stem canker disease in populations of Brassica napus var. oleifera in the field. Plant Pathology 35(4): 551-564.

Hodgson A (1978). Rapeseed adaptation in Northern New South Wales. II. Predicting plant development of Brassica campestris L. and Brassica napus L. and its implications for planting time, designed to avoid water deficit and frost. Australian Journal of Agricultural Research 29 711-726.

Huang Y-J, Evans N, Li Z-Q, Eckert M, Chèvre A-M, Renard M and Fitt BDL (2006). Temperature and leaf wetness duration affect phenotypic expression of Rlm6-mediated resistance to Leptosphaeria maculans in Brassica napus. New Phytologist 170(1): 129-141.

Inderbitzin P, Davis RM, Bostock RM and Subbarao KV (2011). The ascomycete Verticillium longisporum is a hybrid and a plant pathogen with an expanded host range. PLoS ONE 6(3): e18260.

Johansson A, Goud J-K and Dixelius C (2006). Plant host range of Verticillium longisporum and microsclerotia density in Swedish soils. European Journal of Plant Pathology 114(2): 139-149.

Junk J, Eickermann M, Görgen K, Beyer M and Hoffmann L (2012). Ensemble-based analysis of regional climate change effects on the cabbage stem weevil 
(Ceutorhynchus pallidactylus (Mrsh.)) in winter oilseed rape (Brassica napus L.). The Journal of Agricultural Science 150(02): 191-202

Karl TR and Trenberth KE (2003). Modern global climate change. Science 302(5651): 17191723.

Keunecke H (2009). Impact of cabbage root fly on infections and damage potential of Verticillium longisporum and Phoma lingam in oilseed rape, Georg-August-University Göttingen, $231 \mathrm{pp}$.

Kleinhenz B, Koch S, Tiedemann Av and Sander R (2006). Prognose der Weißstängeligkeit mit SkleroPro. Raps 24(2): 68-72.

Kluge E, Enzian S and Gutsche V (1999). Weißstängeligkeit an Winterraps (Sclerotinia sclerotiorum (Lib.) de Bary). In: B.B.f.L.-u. Forstwirtschaft (Editor), Atlas der potentiellen Befallsgefährdung durch wichtige Schadorganismen im Ackerbau Deutschlands. Saphir-Verl., Ribbesbüttel pp. 103-105.

Koch S, Dunker S, Kleinhenz B, Rohrig M and Tiedemann Av (2007). Crop loss-related forecasting model for Sclerotinia stem rot in winter oilseed rape. Phytopathology 97(9): 1186-1194.

Lovell DJ, Powers SJ, Welham SJ and Parker SR (2004). A perspective on the measurement of time in plant disease epidemiology. Plant Pathology 53(6): 705-712.

Magarey RD, Sutton TB and Thayer CL (2005). A simple generic infection model for foliar fungal plant pathogens. Phytopathology 95(1): 92-100.

Manning WJ and Tiedemann Av (1995). Climate change: Potential effects of increased atmospheric carbon dioxide $\left(\mathrm{CO}_{2}\right)$, ozone $\left(\mathrm{O}_{3}\right)$, and ultraviolet-B $(\mathrm{UV}-\mathrm{B})$ radiation on plant diseases. Environmental Pollution 88(2): 219-245.

Mila AL and Yang XB (2008). Effects of fluctuating soil temperature and water potential on sclerotia germination and apothecial production of Sclerotinia sclerotiorum. Plant Disease 92(1): 78-82.

Morrison MJ, McVetty PBE and Shaykewich CF (1989). The determination and verification of a baseline temperature for the growth of Westar summer rape. Canadian Journal of Plant Science 69(2): 455-464.

Morrison MJ and Stewart DW (2002). Heat stress during flowering in summer Brassica. Crop Science 42: 797-803.

Natali SM, Schuur EAG, Trucco C, Hicks Pries CE, Crummer KG and Baron Lopez AF (2011). Effects of experimental warming of air, soil and permafrost on carbon balance in Alaskan tundra. Global Change Biology 17(3): 1394-1407. 
Niu S, Sherry RA, Zhou X, Wan S and Luo Y (2011). Nitrogen regulation of the climatecarbon feedback: Evidence from a long-term global change experiment. Ecology 91(11): 3261-3273.

Olesen JE and Bindi M (2002). Consequences of climate change for European agricultural productivity, land use and policy. European Journal of Agronomy 16(4): 239-262.

Patil RH, Laegdsmand M, Olesen JE and Porter JR (2010). Growth and yield response of winter wheat to soil warming and rainfall patterns. The Journal of Agricultural Science 148: 553-566.

Pritchard SG (2011). Soil organisms and global climate change. Plant Pathology 60(1): 82-99.

Qaderi MM, Kurepin LV and Reid DM (2012). Effects of temperature and watering regime on growth, gas exchange and abscisic acid content of canola (Brassica napus) seedlings. Environmental and Experimental Botany 75(0): 107-113.

Rygulla W, Snowdon RJ, Eynck C, Koopmann B, Tiedemann Av, Luhs W and Friedt W (2007). Broadening the genetic basis of Verticillium longisporum resistance in Brassica napus by interspecific hybridization. Phytopathology 97(11): 1391-1396.

Salam MU, Khangura RK, Diggle AJ and Barbetti MJ (2003). Blackleg Sporacle: A model for predicting onset of pseudothecia maturity and seasonal ascospore showers in relation to blackleg of canola. Phytopathology 93(9): 1073-1081.

Scherm H (2004). Climate change: can we predict the impacts on plant pathology and pest management? Canadian Journal of Plant Pathology 26: 267-273.

Schrödter H (1965). Methodisches zur Bearbeitung phytometeoropathologischer Untersuchungen, dargestellt am Beispiel der Temperaturrelation. Journal of Phytopathology 53: 154-166 (German with English Abstract).

Seem RC (2004). Forecasting plant disease in a changing climate: a question of scale. Canadian Journal of Plant Pathology 26(3): 274-283.

Sharma K, Gossen BD and McDonald MR (2011). Effect of Temperature on Cortical Infection by Plasmodiophora brassicae and Clubroot Severity. Phytopathology 101(12): 1424-1432.

Sheik CS, Beasley WH, Elshahed MS, Zhou X, Luo Y and Krumholz LR (2011). Effect of warming and drought on grassland microbial communities. ISME Journal 5(10): 16921700 .

Teo BK, Morrall RAA and Verma PR (1989). Influence of soil moisture, seedling date, and canola cultivars (Tobin and Westar) on the germination and rotting of sclerotia of Sclerotinia sclerotiorum. Canadian Journal of Plant Pathology 11: 393-399. 
Verburg PSJ, Van Loon WKP and Lükewille A (1999). The CLIMEX soil-heating experiment: soil response after 2 years of treatment. Biology and Fertility of Soils 28(3): 271-276.

Weigel HJ (2005). Healthy plants in the future: how does climate change affect crop production? Gesunde Pflanzen 57(1): 6-17 (German with English Abstract).

West JS, Townsend JA, Stevens M and Fitt BDL (2012). Comparative biology of different plant pathogens to estimate effects of climate change on crop diseases in Europe. European Journal of Plant Pathology 133(1): 315-331.

Whitmore AP and Whalley WR (2009). Physical effects of soil drying on roots and crop growth. Journal of Experimental Botany 60(10): 2845-2857.

Zavaleta ES, Shaw MR, Chiariello NR, Mooney HA and Field CB (2003). Additive effects of simulated climate changes, elevated $\mathrm{CO}_{2}$, and nitrogen deposition on grassland diversity. Proceedings of the National Academy of Sciences of the United States of America 100(13): 7650-7654.

Zearfoss AD, Cowger C and Ojiambo PS (2011). A degree-day model for the latent period of Stagonospora nodorum blotch in winter wheat. Plant Disease 95(5): 561-567. 


\section{Summary}

Climate change is expected to cause a mean annual temperature increase in Germany of $2^{\circ} \mathrm{C}$ by 2050 and up to $4^{\circ} \mathrm{C}$ by 2100 , which will have effects on both crop and fungal pathogen development. Within the research framework "KLIFF - Climate Impact and Adaptation Research in Lower Saxony", potential effects of higher air and soil temperatures on the life cycle of economically important fungal pathogens of oilseed rape (Brassica napus L.) were investigated both theoretically and experimentally. Within the theoretical approach, published knowledge about temperature effects on certain life cycle stages of Leptosphaeria maculans (Phoma lingam), Sclerotinia sclerotiorum and Verticillium longisporum, such as survival, sporulation, infection and further disease development, was collected. Cardinal temperatures of each life cycle stage were compared with current regional climate projections (REMO model) based on emission scenario A1B for the periods 2001 to 2030 and 2071 to 2100 in three different oilseed rape growing regions in Lower Saxony, using a baseline historical series of meteorological data collected from 1971 to 2000. This analysis suggests that higher temperatures may lead to shifts in future prevalence of these pathogens. While Verticillium longisporum and Sclerotinia sclerotiorum could be particularly favored during their early development stages, potentially leading to higher disease severity, Phoma lingam may only benefit in currently colder oilseed rape growing regions.

In order to study effects of rising air and soil temperatures on the soil- and debris-borne life cycle stages of the three pathogens, experiments utilizing climate chambers and a newly constructed soil warming facility were carried out. Warming treatments reflected both regional temperature differences as well as mid- and long-term warming scenarios for Lower Saxony. Investigations included (1) infection of oilseed rape by Verticillium longisporum and further disease progress, (2) carpogenic germination of Sclerotinia sclerotiorum in spring and (3) phoma leaf spot and crown canker development in autumn and spring (field only). Results of climate chamber and field experiments were compared on a thermal time scale based on degree-days in spring.

A mean temperature increase of $2^{\circ} \mathrm{C}$ may lead to advancement of oilseed rape flowering, but also apothecia production of S. sclerotiorum by 5 to 7 days. Hence, the coincidence between ascospore release from apothecia and end of oilseed rape flowering, leading to optimal infection conditions, may still occur under future warming, just earlier in the year. Warming may also advance the beginning of exponential growth of $V$. longisporum within the plant by 7 to 9 days, potentially leading to stronger colonization of susceptible cultivars and inoculum 
accumulation in the soil, which may result in higher yield losses in the future. Development of phoma symptoms may not necessarily be favored by higher temperatures. These assumptions, however, are only based on projected temperature increases and restricted by a lack of reliable, high-resolution future climate scenarios, also for other important weather parameters influencing pathogen development, such as soil moisture, relative humidity and precipitation. Assumptions are furthermore complicated by the prospective adaptations of farming techniques and crop genotypes to climate change. 


\section{Appendix:}

\section{Salicylic acid accumulation in field grown oilseed rape infected with Verticillium longisporum}

\section{Introduction}

Plant responses to different environmental stresses are accomplished by signaling networks involving the different phytohormones salicylic acid, jasmonic acid, ethylene, abscisic acid and reactive oxygen species (Loake and Grant 2007). Salicylic acid (SA) plays a key role in the regulation of plant growth and the response to a broad range of environmental stresses, including heat stress and infection by both biotrophic and necrotrophic pathogens, and is involved in triggering systemic acquired resistance (Chen et al. 2009; Horvath et al. 2007), For example, an increased SA content was found in tobacco inoculated with tobacco mosaic virus (TMV, Enyedi et al. 1992) and cucumber inoculated with tobacco necrosis virus (TNV, Mölders et al. 1996). In both studies, SA was produced locally and translocated from the infection site to other plant parts. In rice, on the other hand, SA may not play a role in disease resistance due to high constitutive levels of SA (Silverman et al. 1995). In previous greenhouse experiments, increased levels of SA and salicylic acid glycoside, the conjugated form which is often considered as a storage form of SA (Vasyukova and Ozeretskovskaya 2007), have been measured in the stem of rapid-cycling rape inoculated with the vascular pathogen Verticillium longisporum (Ratzinger et al. 2009; Riediger 2008). Such studies, however, have not been carried out with different winter oilseed rape cultivars to test whether salicylic acid accumulation is enhanced in resistant genotypes. Furthermore, studies on field grown oilseed rape are lacking. Thus, the main aim of this investigation was to determine whether SA plays a role in oilseed rape - $V$. longisporum interaction under field conditions.

\section{Materials and methods}

\section{Plant material}

The stem samples from the soil warming experiment 2010/11 (compare chapter 4, sampling time points 5 May, 25 May, 16 June and 7 July), which were obtained for qPCR analysis, were additionally used for salicylic acid measurements. 


\section{Extraction of salicylic acid from plant samples}

Freeze-dried and milled samples were spiked prior to phytohormone extraction with the deuterated internal standard d6-SA. To $100 \mathrm{mg}$ of dried shoot material (four plants per pool and two pooled samples per replicate), $1 \mathrm{ml}$ of extraction solvent (20\% aceton, $79 \% \mathrm{H}_{2} \mathrm{O}$ and $1 \%$ acetic acid) spiked with standard stock solution $(200 \mathrm{ng} / \mathrm{ml}$ in methanol) were added. The mixture was shaken $45 \mathrm{~min}$ in the dark at $160 \mathrm{rpm}$. $1 \mathrm{ml}$ of Diethyl ether (DEE) was added and the suspension shaken on ice for $30 \mathrm{~min}$ at $160 \mathrm{rpm}$. Samples were centrifuged at 13,000 $\mathrm{g}$ for $5 \mathrm{~min}$, the phases were separated and the polar phase (DEE + solved phytohormones) dried under vacuum at $30^{\circ} \mathrm{C}$ for $30 \mathrm{~min}$. The residue was dissolved in $200 \mu \mathrm{MeOH} / \mathrm{H}_{2} \mathrm{O}(1: 1)$ and $7 \mathrm{mM} \mathrm{CH}_{3} \mathrm{COOH}$, incubated at room temperature, separated and the polar phase added to HPLC vials.

\section{Quantification of salicylic acid and salicylic acid glucoside by HPLC-ESI-MS/MS}

Extracted samples $(10 \mu \mathrm{l})$ were injected in the HPLC and eluted at $40^{\circ} \mathrm{C}$ with a flow rate of

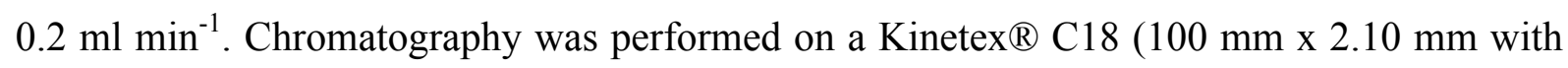
$2.6 \mu \mathrm{m}$ particle size $)$ column equipped with a C18 guard column $(2.0 \mathrm{~mm})$ purchased from Phenomex Inc.(Aschaffenburg, Germany). The following program was used for elution: 90\% solvent A ([95:5] [H20:Acetonitrile] containing $7 \mathrm{mM}$ acetic acid) and 10\% solvent $\mathrm{B}$ (MeOH containing $7 \mathrm{mM}$ acetic acid) for $1 \mathrm{~min}$; ramp to $20 \% \mathrm{~B}$ in $3 \mathrm{~min} 19 \mathrm{sec}$, ramp to $30 \% \mathrm{~B}$ in 36 sec; ramp to $98 \% \mathrm{~B}$ in $1.0 \mathrm{~min}$; hold for $2 \mathrm{~min} 32 \mathrm{sec}$ followed by re-equilibration to $10 \% \mathrm{~B}$. Phytohormones were detected in the mass spectrometer in multiple reaction monitoring modus (MRM) with the following mass transitions: SA 136.8/93.0 (CE 14.5 eV); d6-SA 140.9/97.0 (18.5 eV), SAG 298.8/137.0 (14.5eV). For the quantification of SA, a calibration curve of the ratio of peak areas of the unlabeled standard to the peak area of the deuteriumlabelled standard was used. SAG was quantified with an external calibration curve obtained with pure SAG. Measurements were successful for $70 \%$ of samples.

\section{Statistics}

Two-way ANOVA and Tukey HSD test were carried out to check for the effects of cultivar and warming treatment on the salicylic acid content of stem samples. Pearson correlation coefficients were calculated to explore the relationship between $V$. longisporum DNA content and salicylic acid content of stem samples. For all analyses, p-values $<0.05$ were considered significant. 


\section{Results and Discussion}

Salicylic acid (SA) was detected in samples obtained at all sampling time points (Fig. A1). On 5 May, the susceptible cultivar Falcon accumulated significantly more SA than the resistant cultivar SEM. Furthermore, plants from T2 plots $\left(+3.2^{\circ} \mathrm{C}\right)$ accumulated significantly more SA than plants from $\mathrm{T}$ plots (unheated control). At all other sampling time points there were no significant differences between cultivars and warming treatments, although on average SA accumulation in Falcon was higher than in SEM. SA content of the stem samples was slightly increased on 16 June and strongly increased until 7 July. Final SA contents of field samples were much higher than SA levels of greenhouse plants measured previously (Ratzinger et al. 2009). Salicylic acid glycoside (SAG) was detected in much lower amounts compared to SA. Lowest amounts were detected on 5 May and 7 July with an increase between these dates, especially in heated plots. However, there was no significant effect of cultivar or warming treatment on SAG content at any sampling time point. The lowest amount of SAG at the time of highest SA content of samples suggest that SAG mainly serves as storage form in oilseed rape. Large differences in SA and SAG concentrations among individual infected plants as a result of varying levels of infection have been reported in previous studies (Ratzinger et al. 2009; Riediger 2008).
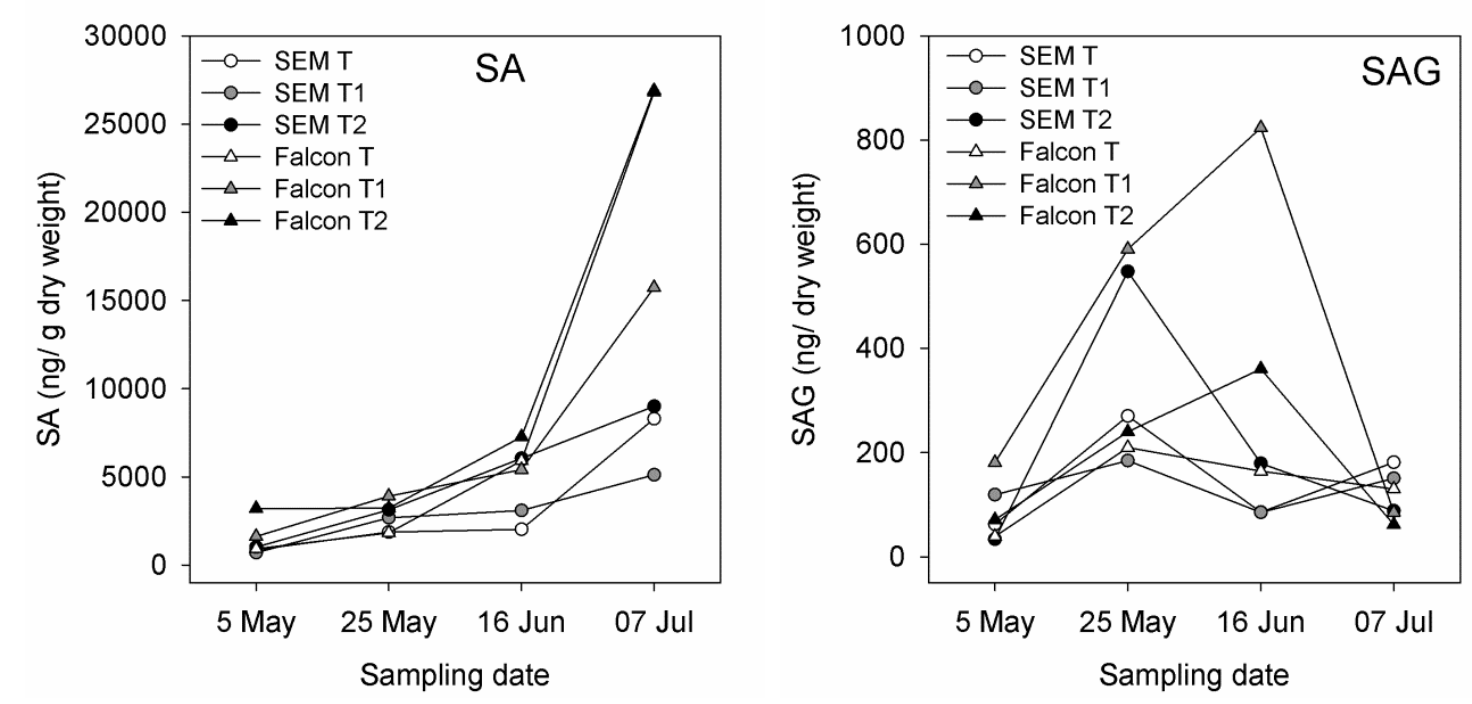

Fig A1: Salicylic acid (SA) and salicylic acid glycoside (SAG) in oilseed rape stems sampled at the soil warming facility Göttingen at different time points in 2011. 
Correlations between $V$. longisporum DNA content of root, hypocotyl and stem and SA content of stem samples were significant, and particularly strong for the susceptible cultivar Falcon (Fig. A2c). In contrast to Ratzinger et al. (2009), however, we could not find a correlation between SAG in stems and fungal biomass in the hypocotyl. Correlations between salicylic acid glycoside (SAG) and $V$. longisporum DNA were negative and not significant for all tissue types (data not shown).
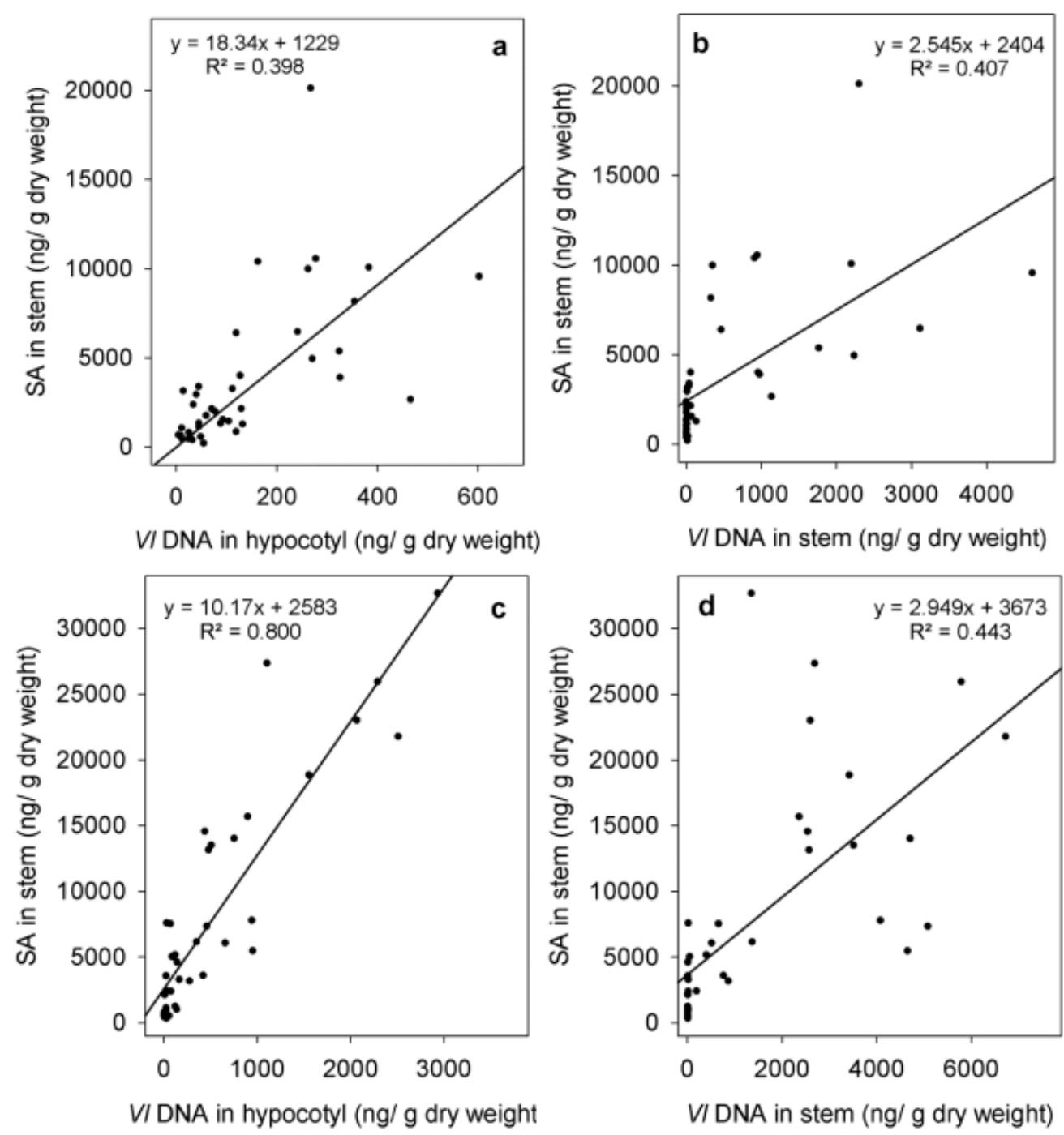

Fig A2: Correlation between $V$. longisporum DNA content of hypocotyl and stem samples and salicylic acid (SA) content of stem samples of the moderately resistant cultivar SEM (a,b) and the susceptible cultivar Falcon $(\mathrm{c}, \mathrm{d})$ across all sampling time points and warming treatments at the soil warming facility Göttingen at four sampling time points in 2011. 
Since uninfected control plants for the determination of constitutive SA levels were not available, it is not clear whether SA accumulation was increased in the stem tissue as a result of infection. However, the strong correlation of SA with $V l$-DNA in the cultivar Falcon, which is highly susceptible to $V$. longisporum, suggests that SA accumulation in winter oilseed rape may be a sign of stress and thus a marker for susceptibility rather than a resistance response. This hypothesis is supported by other recent studies on SA accumulation in oilseed rape cultivars susceptible and resistant towards $V$. longisporum (Daniel Lopisso and Avinash Kamble, pers. comm.). Since no increased SA levels compared to control plants have been measured in plants inoculated with $V$. dahliae (Riediger 2008), which does not colonize the stem, fungal spread from hypocotyl into the stem may be responsible for triggering SA accumulation. Since constitutive levels of SA are likely to differ between different cultivars within the same species and between different organs of the same plant (Vasyukova and Ozeretskovskaya 2007), it is not possible to estimate the exact biological role of SA in the oilseed rape- $V l$ interaction investigated here. After all, stronger SA accumulation in Falcon compared to SEM may only reflect differences in constitutive levels of SA between those two varieties, and the increase of SA towards ripening may reflect the natural change in plant metabolism from vegetative to generative growth stages. For further studies, it is recommended to sample uninfected control plants as well as to measure the SA content of all tissue types which have been subjected to qPCR analysis.

\section{Acknowledgements}

This work was financially supported by the Ministry for Science and Culture of Lower Saxony, Germany, within the research network "KLIFF" - climate impact in Lower Saxony". We are grateful to Lucia Ramos Romero and Nadine Reimann for their help during salicylic acid extraction and to Dr. Richard Splivallo for HPLC measurements. 


\section{References}

Chen Z, Zheng Z, Huang J, Lai Z and Fan B (2009). Biosynthesis of salicylic acid in plants. Plant Signaling and Behavior 4(6): 493-496.

Enyedi AJ, Yalpani N, Silverman P and Raskin I (1992). Localization, Conjugation, and Function of Salicylic Acid in Tobacco During the Hypersensitive Reaction to Tobacco Mosaic Virus. Proceedings of the National Academy of Sciences of the United States of America 89(6): 2480-2484.

Horvath E, Szalai G and Janda T (2007). Induction of abiotic stress tolerance by salicylic acid signaling. Journal of Plant Growth Regulation 26(3): 290-300.

Loake G and Grant M (2007). Salicylic acid in plant defence-the players and protagonists. Current Opinion in Plant Biology 10(5): 466-472.

Mölders W, Buchala A and Metraux JP (1996). Transport of Salicylic Acid in Tobacco Necrosis Virus-Infected Cucumber Plants. Plant Physiology 112(2): 787-792.

Ratzinger A, Riediger N, Tiedemann Av and Karlovsky P (2009). Salicylic acid and salicylic acid glucoside in xylem sap of Brassica napus infected with Verticillium longisporum. Journal of Plant Research 122(5): 571-579.

Riediger N (2008). Beteiligung systemischer Signale an der Symptomauslösung bei Brassica napus nach Infektion mit Verticillium longisporum und $V$. dahliae, Georg-August University Göttingen, 184 pp.

Silverman P, Seskar M, Kanter D, Schweizer P, Metraux J-P and Raskin I (1995). Salicylic Acid in Rice: Biosynthesis, Conjugation, and Possible Role. Plant Physiology 108(2): 633-639.

Vasyukova NI and Ozeretskovskaya OL (2007). Induced plant resistance and salicylic acid: A review. Applied Biochemistry and Microbiology 43(4): 367-373. 


\section{Acknowledgements}

First of all, I am grateful to Prof. Andreas von Tiedemann for being a supportive and encouraging supervisor.

I also thank Prof. Hans-Joachim Weigel for accepting the role as second examiner.

The financial support of the Ministry for Science and Culture of Lower Saxony, Germany, within the research network "KLIFF" - climate impact and adaptation research in Lower Saxony" is gratefully acknowledged. Furthermore, I thank the British Society for Plant Pathology and the DAAD for providing travel funds.

Thanks go to Dr. Peter Juroszek for his assistance in purchasing and setting up the climate chambers and the soil warming facility at the beginning of the project.

I thank all colleagues from the General Plant Pathology and Crop Protection group for the great working atmosphere (and the yummy food) and for being such great volleyball buddies! Particularly, I am grateful to Jessica Knüfer for her advice in molecular issues and for the special atmosphere in our lab.

Big thanks go to Jutta Schaper, Evelin Vorbeck and Dagmar Tacke for their assistance in the lab and elsewhere. Without the helping hands of Jessica Borkmann, Magdalena Bömeke, Elena Ernst, Jacqueline Moser, Claudia Nordmann and Lucia Ramos-Romero sample obtaining and processing would have been impossible. Furthermore, I am grateful to Frank Gremmes, Marc Fiebrich and Tom Österreich for all their technical assistance, and to Eugen Hodyl and Hubertus Reintke for keeping an eye on the plants. Thanks also go to Martina Bode for her administrative support.

Last, but not least, very special thanks go to my brother Mathias who has always set a good example scientifically, and to my parents for their everlasting support. 


\section{Publications from this work}

\section{Peer-reviewed articles:}

Siebold M, Tiedemann Av (2013) Effects of experimental warming on fungal disease progress in oilseed rape. Global Change Biology, doi: 10.1111/gcb.12180

Siebold M, Tiedemann Av (2012) Application of a robust experimental method to study soil warming effects on oilseed rape. Agricultural and Forest Meteorology 164:20-28

Siebold M, Tiedemann Av (2012) Potential effects of global warming on oilseed rape pathogens in Northern Germany. Fungal Ecology 5(1): 62-72

\section{Non peer-reviewed articles:}

Siebold M, Tiedemann Av (2011) Klima puscht Krankheitsdruck. DLZ Agrarmagazin 1: 138-140.

Siebold M, Tiedemann Av (2011) Erhöhter Krankheitsdruck im Raps durch Klimawandel? Raps 2: 8-10.

\section{Selected conference contributions:}

Siebold M, Tiedemann Av (2011) Potential effects of global warming on oilseed rape pathogens in Northern Germany, oral presentation at the IOBC working group meeting Integrated Control in Oilseed Crops, 4 -6 October 2011, Göttingen, Germany

Siebold M, Tiedemann Av (2011) Effects of soil warming on three soil and plant debris borne fungal pathogens of oilseed rape, oral presentation at the XVI Congress of European Mycologists, 19 - 23 September 2011, Chalkidiki, Greece,

Abstract: Book of Abstracts, XVI Congress of European Mycologists, Chalkidiki, Greece, p. 102

Siebold M, Juroszek P, Tiedemann Av (2010) Potentielle Auswirkungen des Klimawandels auf Rapspathogene in Deutschland, oral presentation at the $57^{\text {th }}$ German Plant Protection Conference, 6 - 9 September 2010, Berlin, Germany

Abstract: Julius-Kühn-Archiv 428, pp. 98-99.

Siebold M, Tiedemann Av (2010) Effects of global warming on different life cycle stages of oilseed rape pathogens in Germany - a meta-analytical approach, poster presentation at the $9^{\text {th }}$ International Mycological Congress, 1 - 6 August 2010, Edinburgh, UK 


\section{CURRICULUM VITAE}

\section{PERSONAL DETAILS}

$\begin{array}{ll}\text { Name } & \text { Magdalena Siebold } \\ \text { Date of birth } & 03.12 .1983 \\ \text { Place of birth } & \text { Mühlhausen/ Thuringia } \\ \text { Nationality } & \text { German }\end{array}$

SECONDARY EDUCATION

$1997-2003 \quad$ Grammar school Porta Westfalica, A-levels

1990 - 1997 Primary school/ grammar school Mühlhausen

\section{TERTIARY EDUCATION}

$2009-2012$

$2008-2009$

$2007-2009$

$2006-2007$

$2003-2006$
PhD student at the Department of Crop Sciences, Section General Plant Pathology and Crop Protection, University of Göttingen

Research visit at the University of Aberdeen for Master thesis Masters programme Phytomedicine at the University of Natural Resources and Applied Life Sciences, Vienna, Austria, graduation with Dipl.-Ing. (M.Sc.)

ERASMUS exchange year at the University of Aberdeen Undergraduate studies in agricultural science at the GeorgAugust-University Göttingen, graduation with Bachelor of Science (B.Sc.) 


\section{Declaration}

I, hereby, solemnly declare that this dissertation was undertaken independently and without any unauthorised aid.

Göttingen, 10.09.2012 